\title{
SARS-CoV-2 Transmission in Alberta, British Columbia, and Ontario, Canada, January 1-July 6,
}

Running Title: SARS-CoV-2 transmission in 3 Canadian provinces

Authors: Isaac Chun-Hai Fung, PhD; Yuen Wai Hung, PhD; Sylvia K. Ofori, MPH; Kamalich MunizRodriguez, MPH; Po-Ying Lai, MS; Gerardo Chowell, PhD.

Affiliations: Department of Biostatistics, Epidemiology and Environmental Health Sciences, Jiann-Ping Hsu College of Public Health, Georgia Southern University, Statesboro, Georgia, USA (Ms. Ofori, Ms. Muniz-Rodriguez, Dr. Fung); Department of Health Sciences, Wilfrid Laurier University, Waterloo, Ontario, Canada (Dr. Hung); Department of Biostatistics, School of Public Health, Boston University, Boston, Massachusetts, USA (Ms. Lai); Department of Population Health Sciences, School of Public Health, Georgia State University, Atlanta, Georgia, USA (Dr. Chowell)

Correspondence should be addressed to Dr. Isaac Chun-Hai Fung, Department of Biostatistics, Epidemiology and Environmental Health Sciences, Jiann-Ping Hsu College of Public Health, P.O. Box 7989, Georgia Southern University, Statesboro, GA 30460-7989, USA. Tel: +1 912-478-5079. Email: cfung@georgiasouthern.edu

\section{ORCID}

Isaac Chun-Hai Fung: https://orcid.org/0000-0001-5496-2529

Yuen Wai Hung: https://orcid.org/0000-0002-1171-109X

Sylvia Ofori: https://orcid.org/0000-0002-9961-9975

Kamalich Muniz-Rodriguez: https://orcid.org/0000-0002-4786-9438

Po Ying Lai: https://orcid.org/0000-0002-6156-1878

Gerardo Chowell: https://orcid.org/0000-0003-2194-2251 


\section{Original research article (max 4000 words)}

\section{Acknowledgements}

G.C. received support from NSF grant 1414374 as part of the joint NSF-NIH-USDA Ecology and Evolution of Infectious Diseases program. I.C.-H.F. received salary support from the Centers for Disease Control and Prevention (CDC) (19IPA1908208). This article is not part of I.C.-H.F's CDC-sponsored projects.

\section{Disclaimers}

The opinions expressed in this article do not represent the official positions of the Centers for Disease Control and Prevention or the United States Government.

\section{Author Contributions}

Dr. Fung is the first and corresponding author. Dr. Hung, Ms. Ofori, Ms. Muniz-Rodriguez and Ms. Lai contributed equally as co-second authors. Dr. Chowell serves as the senior author. 
medRxiv preprint doi: https://doi.org/10.1101/2020.07.18.20156992; this version posted August 26, 2020. The copyright holder for this preprint (which was not certified by peer review) is the author/funder, who has granted medRxiv a license to display the preprint in perpetuity.

It is made available under a CC-BY-NC-ND 4.0 International license .

Abstract $200-(\max .200 ;$ structured $)$

Objective: To investigate COVID-19 epidemiology in Alberta, British Columbia and Ontario, Canada.

Methods: We calculated the incidence rate ratio (January 1-July 6, 2020) between the 3 provinces, and estimated time-varying reproduction number, $R_{t}$, starting from March 1, using EpiEstim package in R.

Results: Using British Columbia as a reference, the incidence rate ratios in Alberta and Ontario are 3.1 and 4.3 among females, and 3.4 and 4.0 among males. In Ontario, $R_{t}$ fluctuated $\sim 1$ in March, reached values $>1$ in early and mid-April, then dropped $<1$ in late April and early May. $R_{t}$ rose to $\sim 1$ in mid-May and then remained $<1$ from late May through early July. In British Columbia, $R_{t}$ dropped $<1$ in early April, but it increased towards the end of April. $R_{t}<1$ in May while it fluctuated around 1.0 in June and early July. In Alberta, $R_{t}>1$ in March; $R_{t}$ dropped in early April and rose again in late April. In much of May, $R_{t}<1$, but $R_{t}$ increases in early June and fluctuates $\sim 1$ since mid-June.

Conclusions: $R_{t}$ wavering around 1.0 indicated that three provinces of Canada have managed to achieve limited onward transmission of SARS-CoV-2 as of early July 2020.

Keywords: Canada, Coronavirus, COVID-19, Epidemiology, Infectious Disease, Transmission, SARSCoV-2 


\section{Main Text -3976 (max. 4000)}

\section{Introduction}

In 2020, the pandemic of coronavirus disease 2019 (COVID-19), caused by the severe acute respiratory syndrome virus 2 (SARS-CoV-2), spread across Canada. The first imported case was presented in a Toronto hospital on January 23. 2020. ${ }^{1,2}$ On March 13, Quebec was the first province to declare a public health emergency ${ }^{3}$ four days later, Alberta, British Columbia and Ontario also declared public health emergencies (Table S1). ${ }^{4}$ As of July 10, a cumulative total of 107,126 cases, including 8759 deaths, have been reported in Canada. ${ }^{5}$ As seen in the Canadian government's outbreak update, ${ }^{6,7}$ the national epidemic trajectory appears to have stabilized in early July, but spatial-temporal pattern displays substantial heterogeneity across provinces.

Epidemiologists have explored various aspects of the pandemic in Canada, including data availability, ${ }^{8}$ syndromic surveillance, ${ }^{9}$ disease burden and mortality, ${ }^{10}$ as well as the epidemiology in specific settings or subpopulations, such as nursing homes, ${ }^{11}$ and intensive care units. ${ }^{12}$ Mathematical modelers have also made projections of epidemic trajectories to assist Ottawa and the provincial governments in their decision-making. ${ }^{713-16}$ Against the backdrop of recent literature, our study provides a unique perspective by estimating and interpreting the time-varying reproduction number, $R_{t}$, of SARS-CoV-2 at both provincial and subprovincial levels in 3 Canadian provinces.

This study described the COVID-19 pandemic as it unfolded in Alberta, British Columbia, and Ontario. Our objectives are to compare COVID-19 incidence rates from January 1 to July 6, 2020, and to estimate the time-varying reproduction number, $R_{t}$, of SARS-CoV-2 since the beginning of March 2020.

\section{Methods}

Scope and data sources. We investigated the descriptive epidemiology and the $R_{t}$ of SARS-CoV-2 in Alberta, British Columbia, and Ontario, and their public health subdivisions, using publicly available line lists of COVID-19 case data downloaded from provincial government websites. Alberta, British 
medRxiv preprint doi: https://doi.org/10.1101/2020.07.18.20156992; this version posted August 26, 2020. The copyright holder for this preprint (which was not certified by peer review) is the author/funder, who has granted medRxiv a license to display the preprint in perpetuity.

It is made available under a CC-BY-NC-ND 4.0 International license .

Columbia, and Ontario were chosen for this analysis given their line list data availability. These datasets contained no personal identifiers to protect patients' privacy. Population data by age and sex for Alberta, British Columbia and Ontario was downloaded from Alberta government website. ${ }^{17}$ At the time of our study, Quebec has not yet made the line list of cases publicly available and was not included herein. As of early July, the cumulative number of cases in the other provinces were relatively small and therefore those provinces were not included. The Canadian government's national line list dataset provided the accurate episode time in epidemiologic weeks instead of dates, and thus could not be analyzed using our method here. All the subprovincial incidence curves and $R_{t}$ trajectories were presented in the Supplementary Materials.

Timeframe. The timeframe of this study started on January 1, 2020 (the accurate episode date of the earliest confirmed case in Ontario) and ended on July 5 (Alberta and Ontario) or 6 (British Columbia), the last episode date or reported date in each of our datasets. This timeframe is characterized by importation of cases from overseas followed by community transmission while social distancing measures were gradually introduced. March 17 was the day when the public health emergency was declared in Alberta, British Columbia and Ontario. ${ }^{4}$ By early July, some mandatory social distancing measures remain implemented therein.

The timeframe for $R_{t}$ estimation began with March 1 . We did not estimate $R_{t}$ in January and February because the small number of cases in Ontario and British Columbia during that time would lead to very uncertain $R_{t}$ estimates. No cases were reported in Alberta before March.

Ontario dataset. The Ontario dataset included cases until the end of July 5, 2020 and was downloaded on July 6, 2020, at 5.34pm (EDT). ${ }^{18}$ In Ontario, the subprovincial unit is a Public Health Unit (PHU). The Ontario dataset contained the following variables: accurate episode date, case reported date, test reported date, specimen date, age group, gender, case acquisition information, clinical outcome, outbreak-related (yes or no), reporting PHU, and the address, city, postal code, website, latitude and longitude of the reporting PHU. 
medRxiv preprint doi: https://doi.org/10.1101/2020.07.18.20156992; this version posted August 26, 2020. The copyright holder for this preprint (which was not certified by peer review) is the author/funder, who has granted medRxiv a license to display the preprint in perpetuity.

It is made available under a CC-BY-NC-ND 4.0 International license .

In contrast to the Alberta and British Columbia datasets, which did not contain information on how the case-patients acquired the virus, the Ontario dataset provided information on how a case-patient acquired the virus (“Case Acquisition Info"): 1761 travel-related cases, 10839 “close contact” cases, 6687 cases with "no epi-link", 14259 outbreak-related cases, 1120 cases with "no info-missing" and 1280 cases with "no info-unknown". In our $R_{t}$ estimation, we categorized all travel-related cases as "imported" cases and all others as "local" as per user instructions for the EpiEstim package. Please note that to run the EpiEstim package, the first case(s) on the first day of a time series must be rendered as "imported" cases. Thus, if the first case(s) of a time series was not travel-related, we manually denoted them as "imported" cases so that $R_{t}$ can be estimated using the EpiEstim package.

Alberta dataset. The Alberta dataset included cases until the end of July 5, 2020 and was downloaded on July 7, 2020 at 7.59am (Eastern Daylight Time, EDT). ${ }^{19}$ In Alberta, each subprovincial unit is a Health Services Zone. The Alberta dataset contained the following variables: date of report, health services zone, gender, age group, case status (clinical outcome) and case type (confirmed or probable). The Alberta dataset contained 7678 confirmed cases and 711 probable cases; both types are included in the main analysis. In the sensitivity analysis, only confirmed cases were analyzed.

British Columbia dataset. The British Columbia dataset included cases until July 6, 2020 and was downloaded on July 7 at 8.01 am (EDT). ${ }^{20}$ In British Columbia, each subprovincial unit is a Health Authority. The British Columbia dataset contained the following variables: date of report, health authorities, sex, age group and classification reported ("Epi-linked" versus laboratory-diagnosed). The British Columbia dataset contained 2970 laboratory-diagnosed cases (aka confirmed cases) and 8 "epilinked" cases (aka probable cases); both are included in the main analysis. In the sensitivity analysis, only laboratory-diagnosed cases were analyzed.

Incidence rate ratio. The incidence rate was calculated by dividing the cumulative number of cases in a province by its total population in 2019. Given that the timeframe of our datasets is essentially the same (with only a difference in 1 day), we did not use person-time as the denominator. We used British 
medRxiv preprint doi: https://doi.org/10.1101/2020.07.18.20156992; this version posted August 26, 2020. The copyright holder for this preprint (which was not certified by peer review) is the author/funder, who has granted medRxiv a license to display the preprint in perpetuity.

It is made available under a CC-BY-NC-ND 4.0 International license .

Columbia as the reference, and calculate the incidence rate ratio (IRR) of Alberta and that of Ontario. We did not calculate the $95 \%$ confidence interval for the estimates, because the estimates were true population estimates and not sample estimates, as we used data from province-wide surveillance systems that cover everyone in the province.

Case fatality ratio. We limited our analysis to individuals whose clinical outcomes are known (either deaths or recovered), and used the following simple estimator to obtain an approximation of the case fatality ratio: case fatality ratio $=$ number of deaths $/($ number of deaths + number of recovered $) .{ }^{21}$

Time-varying reproduction number. In contrast with the basic reproduction number, $R_{0}$, which represents the average number of secondary cases generated by an infectious individual in a totally susceptible population in the absence of interventions or behavioral changes, $R_{t}$ is a time-varying indicator which represents the average number of secondary cases per infectious individual in a population as the epidemic unfolds in the presence of interventions and behavioral changes. $R_{t}>1$ indicates sustained transmission and epidemic growth; $R_{t}<1$ indicates unsustainable transmission and epidemic decline. As the epidemic runs its course, it is possible to quantify $R_{t}$ over time after accounting for reductions in susceptibility in the population as more people acquire immunity through natural infection, behavior changes in the population, and interventions that mitigate the transmission rate. ${ }^{22}$

Instantaneous reproduction number method implemented in $R$ package EpiEstim. There are multiple statistical methods available for $R_{t}$ estimation, ${ }^{23,24}$ one of which is the instantaneous reproduction number method implemented in the R package EpiEstim. ${ }^{25,26}$ This method is considered to be well-suited to nearreal-time estimation of $R_{t}$, and is sensitive to signals of changes in transmission potential given recent implementation and cessation of interventions or behavioral changes. ${ }^{23}$ This method has been applied in various studies to estimate the $R_{t}$ of SARS-CoV-2 in different locations globally. ${ }^{27-34}$ A summary of the instantaneous reproduction number method is provided in the Online Supplementary Materials. 
medRxiv preprint doi: https://doi.org/10.1101/2020.07.18.20156992; this version posted August 26, 2020. The copyright holder for this preprint (which was not certified by peer review) is the author/funder, who has granted medRxiv a license to display the preprint in perpetuity.

It is made available under a CC-BY-NC-ND 4.0 International license .

Software version. Data management and analysis (except for maps) was performed using Microsoft Excel and R version 3.6.2 (R Core Team, Vienna, Austria). Version 2.2-3 of the EpiEstim package was used. Maps were made in R version 3.5.1 (R Core Team, Vienna, Austria).

Ethics. The Georgia Southern University Institutional Review Board made a non-human subjects determination for this project (H20364), under the G8 exemption category.

\section{Results}

The dates of the first cases and the total number of cases in our datasets by each subprovincial public health unit in Alberta, British Columbia and Ontario are presented in Table S2.

Incidence rate ratio and case-fatality ratio at the provincial level. Table S3 presents the number of cases per 100,000 population, stratified by sex/gender and age groups (see Tables S4-S6 for details). Interestingly, the incidence rates in Alberta and Ontario were higher than those in British Columbia, which served as the reference group. Among females, the respective IRR in Alberta and Ontario were 3.1 (187.3/59.9) and 4.3 (259.9/59.9). Among males, the respective IRR in Alberta and Ontario were 3.4 (196.2/57.2) and 4.0 (196.2/57.2). This may reflect a more aggressive testing strategy in Alberta and Ontario. As of July 11, 2020, Alberta and Ontario had the highest rate of testing in Canada (102,299 and 110,612 tests per million population, respectively) whereas in British Columbia the rate was only 36,059 tests per million population. ${ }^{6}$ In both provinces, anyone who feels needing a test, including asymptomatic individuals, can get a test without referral. For example, Ontario waived the requirement to get a referral to qualify for testing on May 24, 2020, and increased testing capacity to over 20,000 a day. ${ }^{35}$ Likewise, Alberta started testing asymptomatic cases around mid-May. The alternative hypothesis was that this might reflect a genuine difference across the 3 provinces in their epidemiology of COVID-19. Tables S7 and S8 present the clinical outcomes of cases in Alberta and Ontario. As expected, the elderly has a high case-fatality ratio than other age groups, as described in a recent study by Bignami and Van Assche,${ }^{10}$ and 
medRxiv preprint doi: https://doi.org/10.1101/2020.07.18.20156992; this version posted August 26, 2020. The copyright holder for this preprint (which was not certified by peer review) is the author/funder, who has granted medRxiv a license to display the preprint in perpetuity.

It is made available under a CC-BY-NC-ND 4.0 International license .

this is similar to observations in other parts of the world, such as England.$^{36}$ Likewise, as in other countries, there had been outbreaks in long-term care facilities in Canada. ${ }^{11,37,38}$

\section{Epidemic curve and $\boldsymbol{R}_{t}$.}

The accurate episode date of the first two cases in Ontario was January 1, 2020, one without epi-link and one being a close contact. The "no epi-link" case was a male in his 80 s whose specimen date was April 23 and whose test result was reported on April 24 (case reported on the same date). The "close contact" case was a male in his 50s whose specimen date was May 15 and whose test result was reported on May 17 (case reported on the same date). A third case was a male in his 50s whose accurate episode date was January 10 and was a "close contact" case but whose specimen was taken on June 9 (test reported and case reported on the next day). This cluster of 3 cases had episode dates before the first two reported cases in Ontario (date of report: January 23, 2020) whose accurate episode dates were January 21 and 22 respectively. ${ }^{1,2}$ In Ontario (Figure 1), $R_{t}$ fluctuated around 1 in March, rose to $>1$ but $<1.25$ in early and mid-April, then dropped $<1$ in late April and early May. $R_{t}$ rose to $\sim 1$ in mid-May and then remained $<1$ from late May through early July.

A map showing the cumulative number of cases over time by PHU in Ontario is presented in Figure 2, and a similar map showing the cumulative number of deaths is in Figure S1. Epidemic trajectories in selected PHUs are as follows. In City of Toronto PHU (Figure S2) and its neighbors, namely, Durham Regional PHU (Figure S3), Peel Regional PHU (Figure S4), and York Regional PHU (Figure S5), we observed similar tragectories: $R_{t} \geq 1$ in sustained period of time from late March to mid-April. $R_{t}$ subsided to $<1$ in late April and early May but rose to $\sim 1$ in mid-May. $R_{t}$ decreased to $<1$ consistently in early June but it was on an increasing trend towards early July. Slightly further away from Toronto, in Halton Regional PHU (Figure S6), $R_{t}$ fluctuates around 1 through the study period. It was $<1$ in much of June. In City of Hamilton PHU (Figure S7), $R_{t}$ fluctuates around 1 through the timeframe of this study, except for mid-May when $R_{t}$ reached a peak of 2 (1-window estimate). In Region of Waterloo PHU (Figure S8), $R_{t}$ fluctuates around 1 in March but increases steadily to $>1$ in mid-April, followed by a continuous drop to 
medRxiv preprint doi: https://doi.org/10.1101/2020.07.18.20156992; this version posted August 26, 2020. The copyright holder for this preprint (which was not certified by peer review) is the author/funder, who has granted medRxiv a license to display the preprint in perpetuity.

It is made available under a CC-BY-NC-ND 4.0 International license .

$<1$, until late May when $R_{t}$ rebounded to around 1 in June. In Niagara Region PHU (Figure S9), $R_{t}$ fluctuates around 1 across the timeframe of this study, except for late May when there was a surge in cases leading to $R_{t}>1$ in late May followed by a trough $<1$ in June. In Ottawa PHU (Figure S10), $R_{t}$ was $<1$ in late March but it increased to slightly $>1$ in April. It maintained $<1$ in much of May and fluctuates around 1 in June. For the other PHUs from Algoma PHU to Windsor-Essex County Health PHU, see Figures S11 to S35.

The first case in British Columbia was reported by Vancouver Coastal Health Authority on January 26, 2020. In British Columbia, $R_{t}$ dropped below 1 the first time in early April, but it increased towards the end of April. For most of May, $R_{t}<1$ while it fluctuated around 1 in June and early July (Figure 3). Figure 4 is a map showing the cumulative number of cases in British Columbia by Health Authority over time. Below are epidemic trajectories in selected Health Authorities. In Vancouver Coastal Health Authority (Figure S36), $R_{t}$ was $\sim 2$ in mid-March and dropped to 1 by April and below $<1$ in mid-April but increased in late April to $\sim 1$. It fluctuates $<1$ for much for May but rose to $\sim 2$ in mid-June, followed by fluctuation around 1 in late June and early July. In Fraser Health Authority (Figure S37), $R_{t}$ fluctuated between 1.5 and 2 in mid-March before dropping to $\sim 1$ through April. In May it fluctuated $<1$ but increased to 1 and fluctuated around 1 in June and early July. For Interior, Northern and Vancouver Island Health Authorities, see Figure S38 to S40. As a sensitivity analysis we analyzed the data excluding 8 probable cases ("epi-linked cases") (Table S9); focusing at the 2970 confirmed cases, the results in $R_{t}$ are similar (Figure S41).

The first case in Alberta was reported in Calgary Zone on March 6, 2020. In Alberta, $R_{t}>1$ in March, corresponding to reaching a peak in incidence in late March and early April. A small dip in $R_{t}$ happened in early April and $R_{t}$ rose again in late April, as the incidence increased and reached a peak in late April. In much of May, $R_{t}<1$, but $R_{t}$ increases in early June and fluctuates around 1 (slightly above 1 ) since midJune (Figure 5). Figure 6 is a map showing the cumulative number of cases in Alberta by Health Services Zone over time, while Figure S42 is a similar map showing the cumulative number of deaths. Below are 
medRxiv preprint doi: https://doi.org/10.1101/2020.07.18.20156992; this version posted August 26, 2020. The copyright holder for this preprint (which was not certified by peer review) is the author/funder, who has granted medRxiv a license to display the preprint in perpetuity.

It is made available under a CC-BY-NC-ND 4.0 International license .

epidemic trajectories in selected Health Services Zones. In Calgary Zone (Figure S43), $R_{t}$ began at $\sim 2$ in mid-March and dropped to $\sim 1$ in early April and rose again to $\sim 1.5$ and maintained $>1$ in the second half of April. In May and early July, $R_{t}$ was $<1$, but increased to $\sim 1$ from mid-June through early July. In Edmonton Zone (Figure S44), it fluctuates around 1.5 in late March, dropped to 1 in early April and <1 in mid-April. $R_{t}$ rose to $\sim 1$ in late April and then maintained at a $<1$ level for much of May. $R_{t}$ increased to $\sim 2$ in late May and early June, and then gradually dropped to $\sim 1$ in early July. In South Zone (Figure S45), Rt fluctuated around 1 in late March and early April and rose to 3 in the second half of April as there was an outbreak from mid-April to early May. Rt below <1 in much of May and fluctuated around 1 in much of June and made a sharp increase to $\sim 2$ in early July. For Central and North Zones, see Figures S46 and S47. As a sensitivity analysis we analyzed the data excluding 711 probable cases; focusing at 7678 confirmed cases only, the results in $R_{t}$ are similar (Figure S48).

Specimen collection date in Ontario dataset. Among the 35948 case-patients in Ontario, the median delay in specimen collection for testing is 1 day after symptom onset (accurate episode date), with an interquartile range from 0 to 5 days. A decrease over time in the average time difference between date of symptom onset and the date of specimen taken, and the variance of that time difference (Figure 7 Panel a) represents the improvement in the testing capacity allowing individuals to get tested promptly after symptom onset. As seen in Figure 4a, the delay on March 1 would be 7.4 days and the delay was close to 0 around June 21. See Appendix for details of the regression model. The longest time difference (an outlier) was a delay of 151 days (that might suggest that these were serological tests and not polymerase chain reaction tests, ${ }^{39}$ but the dataset do not provide further details). A total of 305 (0.8\%) individuals do not have specimen dates. There were 2391 (6.7\%) whose specimens were collected prior to date of symptom onset, i.e. (accurate episode date - specimen date) $<0$. Of these 2391 individuals, 926, 766, 397 and 302 individuals developed symptom 1, 2, 3 or $\geq 4$ days, respectively, after having specimen taken for testing (Table S10). Most of these 2391 case-patients were outbreak-related $(n=1473)$ or close contacts of cases ( $\mathrm{n}=619)$, while 28 were travel-related. However, 211 of them did not have any epi-link, and 24 and 
medRxiv preprint doi: https://doi.org/10.1101/2020.07.18.20156992; this version posted August 26, 2020. The copyright holder for this preprint (which was not certified by peer review) is the author/funder, who has granted medRxiv a license to display the preprint in perpetuity.

It is made available under a CC-BY-NC-ND 4.0 International license .

36 were without case acquisition info ("missing" or "unknown" respectively) (Table S11). This is not surprising, since Ontario enhanced testing capacity for testing asymptomatic people at risk of exposure. Of these 2391 individuals whose specimens taken prior to symptom onset, except for 8 who did not have a test report date, $1463(61 \%)$ had their tests reported the same day as their symptom onset; 307 (13\%), 1 day after symptom onset, $385(16 \%), \geq 2$ days later, and $228(9.5 \%)$ had their test reported before symptom onset (Table S10). Of these 2391 individuals, $1641(69 \%)$ had their case reported the day they developed symptoms, 337 (14\%) on the next day of symptom onset, $413(17 \%)$, $\geq 2$ days after symptom onset (Table S10).

Delay in test report and case report in Ontario dataset. The delay in test report decreased over time. On March 1, the delay was approximately 11 days, while on July 5, it was about 1 day (Figure S49). The delay in case report has also decreased over time. On March 1, the delay was approximately 10 days, while on July 5, it was about 1 day (Figure 7 panel b). See Appendix for details of the regression models.

\section{Discussion}

Alberta, British Columbia and Ontario, Canada, appeared to have managed to achieve limited transmission of SARS-CoV-2 with $R_{t} \sim 1$ at the time of writing in early July 2020 (Figures 1, 3, 5), through a combination of multiple interventions, including community social distancing, increased testing of individuals at higher risk or suspected of SARS-CoV-2 infection, and isolation of COVID-19 cases. Canada's experience with SARS epidemic in 2003 may have contributed to the coordinated government's response in COVID-19. The 2003 SARS epidemic in Canada resulted in a set of recommendations to federal, provincial, and territorial leader, and in particular, led to the creation of the Public Health Agency of Canada which has been leading the response to COVID-19. ${ }^{40}$

Our results show that since mid-March in the 3 Canadian provinces under study, SARS-CoV-2 has been spreading with an $R_{t}<2$ that is smaller than the estimated $\mathrm{R}_{0}$ of $>2 \cdot{ }^{41,42}$ For the majority of the time period 
medRxiv preprint doi: https://doi.org/10.1101/2020.07.18.20156992; this version posted August 26, 2020. The copyright holder for this preprint (which was not certified by peer review) is the author/funder, who has granted medRxiv a license to display the preprint in perpetuity.

It is made available under a CC-BY-NC-ND 4.0 International license .

under study, $R_{t}$ fluctuated around 1. Our analysis of the COVID-19 epidemic by Canadian subprovincial units present a similar picture as our province-level analysis with few exceptions. Nowhere in Canada experienced the trauma that residents in Wuhan, Milan and New York City had experienced. While Canadian provinces have substantial administrative authority over COVID-19 response, the federal and provincial government have collaborated to produce a coordinated response to the pandemic, as evidenced by the similar COVID-19 response measures in the three provinces, as well as the united politicians' communications on the nature and severity of the COVID-19 pandemic, and the necessity of social distancing across the different Canadian political parties. ${ }^{43}$ As the three provinces began reopening businesses, services, and public spaces, all three provinces have been gradually relaunching by stages which depended on local infection rate and the capacity of the healthcare system. ${ }^{44-46}$

Our study has several limitations. First, our $R_{t}$ estimation for Alberta and British Columbia relied on data by reporting date and not date of onset, as the latter was unavailable to us. Only Ontario provided the accurate episode date. Future research can study the epidemic data by date of onset when it is available to researchers to better estimate $R_{t}$. Second, the number of reported cases per day in the Alberta and British Columbia datasets would be influenced by the testing rate, since limited testing capacity could lead to underdiagnosis. We did not attempt to do a nationwide analysis for Canada because the testing criteria has not been consistent across Canadian provinces. Third, our estimates are contingent that the testing ratio does not change significantly over the study period. However, provincial governments might have been ramping out testing capacity during the early epidemic phase in their jurisdiction. Fourth, reporting delays are known to vary over time and could influence the observed trajectory of the epidemics by date of report in Alberta and British Columbia. For Ontario, our results showed that the delay to testing has been reduced over time and Ontario achieved testing on the same or next date since symptom onset in June. It is possible that similar improvement in reduction in testing delay may have happened in Alberta and British Columbia, but we do not have such data. Fifth, improvement in testing over time could potentially reduce generation time over time. As we do not have data on infector-infectee pairs, we cannot estimate if 
medRxiv preprint doi: https://doi.org/10.1101/2020.07.18.20156992; this version posted August 26, 2020. The copyright holder for this preprint (which was not certified by peer review) is the author/funder, who has granted medRxiv a license to display the preprint in perpetuity.

It is made available under a CC-BY-NC-ND 4.0 International license .

serial interval has changed over time. In our $R_{t}$ estimation, our serial interval distribution is parametrically determined a priori based on the literature. ${ }^{47}$ Sixth, the Ontario dataset is by date of symptom onset and therefore the most recent data points may be lower than what they should have been, because there could be cases who had not yet been reported to the provincial government. Thus, the low $R_{t}$ estimate for Ontario in the $1^{\text {st }}$ week of July may be an artifact due to right-censoring of the data. Seventh, we obtained an approximation of the case-fatality ratio using a simple estimator by restricting the analysis to cases with known outcomes. There are estimation methods that are more statistically advanced, ${ }^{21,48,49}$ but they are less accessible to practitioners of applied epidemiology and they are beyond the scope of this paper.

\section{Conclusions}

In conclusion, Alberta, British Columbia, and Ontario managed to keep the $R_{t}$ of SARS-CoV-2 wavering around 1, with our recent estimates indicating sporadic episodes of sustained transmission in Alberta and British Columbia where $R_{t}$ fluctuates around 1 or slightly $>1$ in the first week of July. In Ontario, $R_{t}$ may have been suppressed $<1$ in early July. Sustained social distancing interventions and further limiting case importations could potentially suppress the epidemic by driving $R_{t}<1$ for a sustained period of time.

\section{References}

1. Silverstein WK, Stroud L, Cleghorn GE, Leis JA. First imported case of 2019 novel coronavirus in Canada, presenting as mild pneumonia. Lancet. 2020;395(10225):734.

2. Marchand-Senecal X, Kozak R, Mubareka S, et al. Diagnosis and Management of First Case of COVID-19 in Canada: Lessons applied from SARS. Clin Infect Dis. 2020.

3. National Post. As the COVID-19 pandemic hit, provinces declared states of emergency. Now many are up for renewal. April 15, 2020. 2020; https://nationalpost.com/news/provincial-statesof-emergencies-were-issued-a-month-ago-most-are-coming-up-for-renewal. Accessed May 2, 2020.

4. The Global and Mail. Coronavirus March 17: Ontario, Alberta, B.C. declare states of emergency; B.C. closes schools to combat virus spread. 2020; https://www.theglobeandmail.com/canada/article-the-latest-on-the-coronavirus-cineplex-closesits-doors-a-quieter-st/. Accessed April 7, 2020.

5. Government of Canada. Coronavirus disease 2019 (COVID-19): Epidemiology update (as of July 10, 2020, 7pm EDT). 2020; https://health-infobase.canada.ca/covid-19/epidemiologicalsummary-covid-19-cases.html. Accessed July 11, 2020.

6. Government of Canada. Coronavirus disease (COVID-19): Outbreak update (as of July 12, 2020). 2020; https://www.canada.ca/en/public-health/services/diseases/2019-novel-coronavirusinfection.html. Accessed July 12, 2020. 
medRxiv preprint doi: https://doi.org/10.1101/2020.07.18.20156992; this version posted August 26, 2020. The copyright holder for this preprint (which was not certified by peer review) is the author/funder, who has granted medRxiv a license to display the preprint in perpetuity.

It is made available under a CC-BY-NC-ND 4.0 International license .

7. Government of Canada. Update on COVID-19 in Canada: Epidemiology and Modelling (July 8, 2020). 2020; https://www.canada.ca/content/dam/phac-aspc/documents/services/diseasesmaladies/coronavirus-disease-covid-19/epidemiological-economic-researchdata/update covid 19 Canada epidemiology modelling 20200708.pdf. Accessed July 13, 2020.

8. Berry I, Soucy JR, Tuite A, Fisman D, Group C-CODW. Open access epidemiologic data and an interactive dashboard to monitor the COVID-19 outbreak in Canada. CMAJ. 2020;192(15):E420.

9. Lapointe-Shaw L, Rader B, Astley CM, et al. Syndromic Surveillance for COVID-19 in Canada (Version 1). medRxiv. 2020;2020.05.19.20107391.

10. Bignami S, Van Assche A. Assessing the burden of COVID-19 in Canada (Version 1). medRxiv 2020; https://www.medrxiv.org/content/medrxiv/early/2020/06/16/2020.06.14.20130815.full.pdf, 2020.06.14.20130815.

11. Brown KA, Jones A, Daneman N, et al. Association Between Nursing Home Crowding and COVID-19 Infection and Mortality in Ontario, Canada (Version 1). medRxiv 2020; https://www.medrxiv.org/content/medrxiv/early/2020/06/23/2020.06.23.20137729.full.pdf, 2020.06.23.20137729.

12. Mitra AR, Fergusson NA, Lloyd-Smith E, et al. Baseline characteristics and outcomes of patients with COVID-19 admitted to intensive care units in Vancouver, Canada: a case series. CMAJ. 2020;192(26):E694-E701.

13. Tuite AR, Fisman DN, Greer AL. Mathematical modelling of COVID-19 transmission and mitigation strategies in the population of Ontario, Canada. CMAJ. 2020;192(19):E497-E505.

14. Institut national de santé publique du Québec. Mesures de distanciation et de confinement au Québec: impact et projections. 2020; https://www.inspq.qc.ca/covid-

19/donnees/projections/distanciation. Accessed July 13, 2020.

15. British Columbia Centre for Disease Control. Modelling \& Projections. 2020; http://www.bccdc.ca/health-info/diseases-conditions/covid-19/modelling-projections. Accessed July 13, 2020.

16. Government of Alberta. COVID-19 Modelling (Update, April 8, 2020). 2020; https://www.alberta.ca/assets/documents/covid-19-case-modelling-projection.pdf. Accessed July $13,2020$.

17. Government of Alberta. Population by age and sex: 1971 - 2019. 2020; https://open.alberta.ca/dataset/alberta-population-estimates-data-tables/resource/7e96a710-372545d1-ba58-36ea9cfe144c. Accessed July 8, 2020.

18. Government of Ontario. Confirmed positive cases of COVID-19 in Ontario. 2020; https://data.ontario.ca/dataset/confirmed-positive-cases-of-covid-19-in-ontario. Accessed July 6, 2020.

19. Government of Alberta. COVID-19 Alberta statistics. 2020; https://www.alberta.ca/stats/covid19-alberta-statistics.htm. Accessed July 7, 2020.

20. British Columbia Centre for Disease Control. BC COVID-19 Data. 2020; http://www.bccdc.ca/health-info/diseases-conditions/covid-19/data. Accessed July 7, 2020.

21. Ghani AC, Donnelly CA, Cox DR, et al. Methods for estimating the case fatality ratio for a novel, emerging infectious disease. Am J Epidemiol. 2005;162(5):479-486.

22. Vynnycky E, White RG. An Introduction to Infectious Disease Modelling. Oxford: Oxford University Press; 2010.

23. Gostic KM, McGough L, Baskerville E, et al. Practical considerations for measuring the effective reproductive number, Rt. medRxiv. 2020;2020.06.18.20134858.

24. O'Driscoll M, Harry C, Donnelly CA, Cori A, Dorigatti I. A comparative analysis of statistical methods to estimate the reproduction number in emerging epidemics with implications for the current COVID-19 pandemic. medRxiv. 2020;2020.05.13.20101121.

25. Thompson RN, Stockwin JE, van Gaalen RD, et al. Improved inference of time-varying reproduction numbers during infectious disease outbreaks. Epidemics. 2019;29:100356. 
medRxiv preprint doi: https://doi.org/10.1101/2020.07.18.20156992; this version posted August 26, 2020. The copyright holder for this preprint (which was not certified by peer review) is the author/funder, who has granted medRxiv a license to display the preprint in perpetuity. It is made available under a CC-BY-NC-ND 4.0 International license .

26. Cori A, Ferguson NM, Fraser C, Cauchemez S. A new framework and software to estimate timevarying reproduction numbers during epidemics. Am J Epidemiol. 2013;178(9):1505-1512.

27. Abbott S, Hellewell J, Thompson R, et al. Estimating the time-varying reproduction number of SARS-CoV-2 using national and subnational case counts [version 1; peer review: awaiting peer review]. 2020;5(112).

28. Leung K, Wu JT, Liu D, Leung GM. First-wave COVID-19 transmissibility and severity in China outside Hubei after control measures, and second-wave scenario planning: a modelling impact assessment. Lancet. 2020;395(10233):1382-1393.

29. Cowling BJ, Ali ST, Ng TWY, et al. Impact assessment of non-pharmaceutical interventions against coronavirus disease 2019 and influenza in Hong Kong: an observational study. Lancet Public Health. 2020;5(5):e279-e288.

30. Najafi F, Izadi N, Hashemi-Nazari SS, Khosravi-Shadmani F, Nikbakht R, Shakiba E. Serial interval and time-varying reproduction number estimation for COVID-19 in western Iran. New Microbes New Infect. 2020;36:100715.

31. Zhuang Z, Zhao S, Lin Q, et al. Preliminary estimates of the reproduction number of the coronavirus disease (COVID-19) outbreak in Republic of Korea and Italy by 5 March 2020. Int J Infect Dis. 2020;95:308-310.

32. Moirano G, Schmid M, Barone-Adesi F. Short-Term Effects of Mitigation Measures for the Containment of the COVID-19 Outbreak: An Experience From Northern Italy. Disaster Med Public Health Prep. 2020:1-2.

33. Adegboye OA, Adekunle AI, Gayawan E. Early Transmission Dynamics of Novel Coronavirus (COVID-19) in Nigeria. Int J Environ Res Public Health. 2020;17(9):3054.

34. Scire J, Nadeau S, Vaughan T, et al. Reproductive number of the COVID-19 epidemic in Switzerland with a focus on the Cantons of Basel-Stadt and Basel-Landschaft. Swiss Med Wkly. 2020;150:w20271.

35. Government of Ontario. Protecting Ontarians Through Enhanced Testing. 2020; https://files.ontario.ca/moh-covid-19-protecting-ontarians-through-enhanced-testing-en-2020-0529.pdf. Accessed July 12, 2020.

36. Williamson EJ, Walker AJ, Bhaskaran K, et al. OpenSAFELY: factors associated with COVID19 death in 17 million patients. Nature. 2020;DOI: https://doi.org/10.1038/s41586-020-2521-4.

37. Bensadoun E. Nearly half of Canada's COVID-19 deaths linked to long-term care facilities: Tam. Global News 2020; https://globalnews.ca/news/6811726/coronavirus-long-term-care-deathscanadal. Accessed July 13, 2020.

38. Hsu AT, Lane N. Impact of COVID-19 on residents of Canada's long-term care homes - ongoing challenges and policy response. Report in LTCcovid.org, International Long-Term Care Policy Network, CPEC-LSE, 23 April 2020. 2020; https://ltccovid.org/wpcontent/uploads/2020/04/LTC-COVID19-situation-in-Canada-22-April-2020-1.pdf. Accessed July 13, 2020.

39. Government of Canada. Testing devices for COVID-19: Serological testing devices. 2020; https://www.canada.ca/en/health-canada/services/drugs-health-products/covid19industry/medical-devices/testing/serological.html. Accessed July 13, 2020.

40. Webster P. Canada and COVID-19: learning from SARS. Lancet. 2020;395(10228):936-937.

41. Tsang TK, Wu P, Lin Y, Lau EHY, Leung KSM, Cowling BJ. Effect of changing case definitions for COVID-19 on the epidemic curve and transmission parameters in mainland China: a modelling study. Lancet Public Health. 2020:DOI: 10.1016/S2468-2667(1020)30089-X.

42. Muniz-Rodriguez K, Fung IC-H, Ferdosi SR, et al. Severe Acute Respiratory Syndrome Coronavirus 2 Transmission Potential, Iran, 2020. Emerg Infect Dis. 2020;26(8):DOI: https://doi.org/10.3201/eid2608.200536.

43. Merkley E, Bridgman A, Loewen PJ, Owen T, Ruths D, Zhilin O. A Rare Moment of CrossPartisan Consensus: Elite and Public Response to the COVID-19 Pandemic in Canada. Canadian Journal of Political Science. 2020:1-8. 
medRxiv preprint doi: https://doi.org/10.1101/2020.07.18.20156992; this version posted August 26, 2020. The copyright holder for this preprint (which was not certified by peer review) is the author/funder, who has granted medRxiv a license to display the preprint in perpetuity.

It is made available under a CC-BY-NC-ND 4.0 International license .

44. Government of Alberta. Opening soon: Alberta's relaunch strategy (Updated June 2020). 2020; https://open.alberta.ca/dataset/61f54c09-d6d7-4a12-a5be-0bc663a02c31/resource/e158ff14-eab74f24-94f4-b67c3639d0d5/download/covid-19-alberta-relaunch-strategy-2020-06.pdf. Accessed July 13, 2020.

45. Government of Ontario. Reopening Ontario. 2020; https://www.ontario.ca/page/reopeningontario. Accessed July 13, 2020.

46. Government of British Columbia. BC's Restart Plan. 2020; https://www2.gov.bc.ca/gov/content/safety/emergency-preparedness-response-recovery/covid-19provincial-support/bc-restart-plan. Accessed July 13, 2020.

47. You C, Deng Y, Hu W, et al. Estimation of the time-varying reproduction number of COVID-19 outbreak in China. Int J Hyg Environ Health. 2020;228:113555.

48. Garske T, Legrand J, Donnelly CA, et al. Assessing the severity of the novel influenza A/H1N1 pandemic. BMJ. 2009;339:b2840.

49. Mizumoto K, Chowell G. Estimating Risk for Death from Coronavirus Disease, China, JanuaryFebruary 2020. Emerg Infect Dis. 2020;26(6):1251-1256. 
1 Figure 1. The epidemic trajectory of coronavirus disease 2019 in Ontario, January 1-July 5, 2020: Upper

2 panel: Daily number of new imported and local cases by date of symptom onset (aka accurate episode

3 date) (upper panel); $R_{t}$ with a 1-week window (middle panel); $R_{t}$ with a 2-week window (lower panel).

$4 \quad$ Figure 2. Map of cumulative number of cases in Ontario by public health unit by the end of month and on

5 July 5, 2020.

6 Figure 3. The epidemic trajectory of coronavirus disease 2019 in British Columbia, January 1-July 6,

7 2020: Daily number of new cases by date of report (upper panel); $R_{t}$ with a 1-week window (middle

8 panel); $R_{t}$ with a 2-week window (lower panel).

9 Figure 4. Map of cumulative number of cases in British Columbia by health authority by the end of 10 month and on July 6, 2020.

11 Figure 5. The epidemic trajectory of coronavirus disease 2019 in Alberta, January 1-July 5, 2020: Daily

12 number of new cases by date of report (upper panel), $R_{t}$ with a 1-week window (middle panel) and $R_{t}$ with

13 a 2-week window (lower panel).

14 Figure 6. Map of cumulative number of cases in Alberta by health service zone by the end of month and 15 on July $5,2020$.

Figure 7. (a) Scatter plot of the time difference between symptom onset (accurate episode date) and testing (specimen date) of each case-patient in Ontario over time (accurate episode date), Jan 1-July 6, 2020. (b) Scatter plot of the time difference between symptom onset (accurate episode date) and case report date of each case-patient in Ontario over time (accurate episode date), Jan 1-July 6, 2020. 


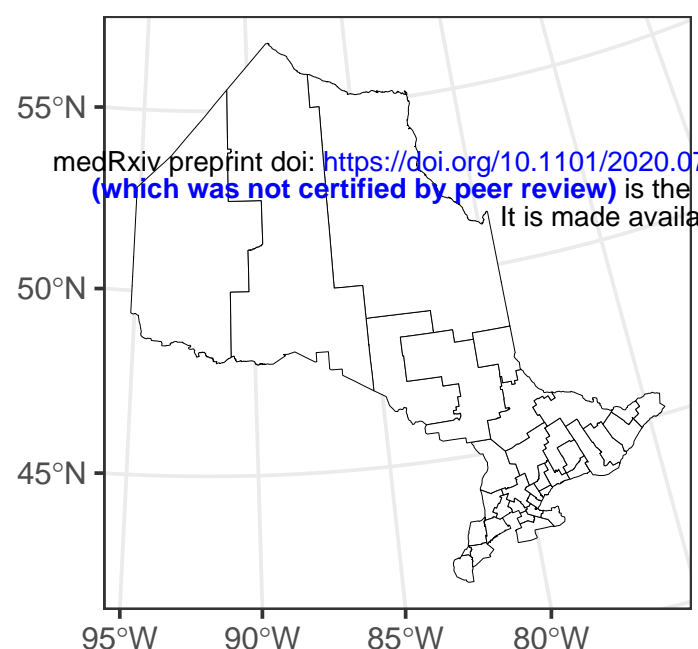

31 March, 2020

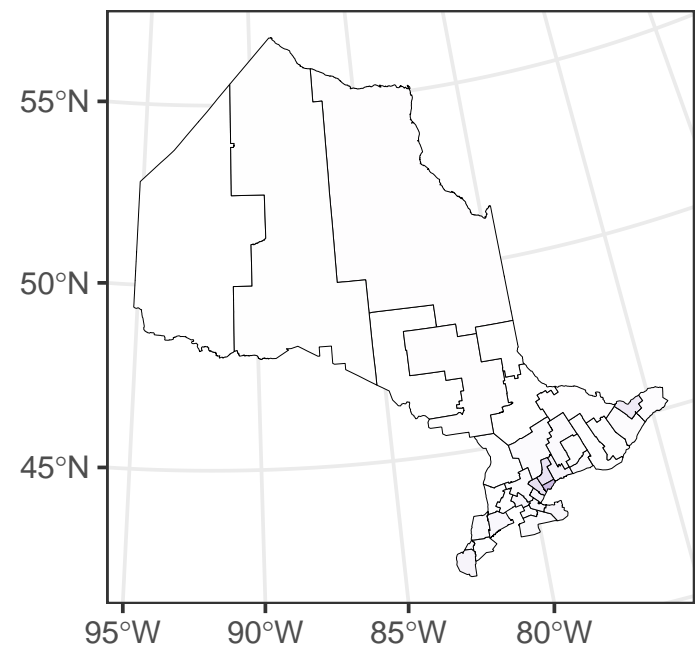

31 May, 2020

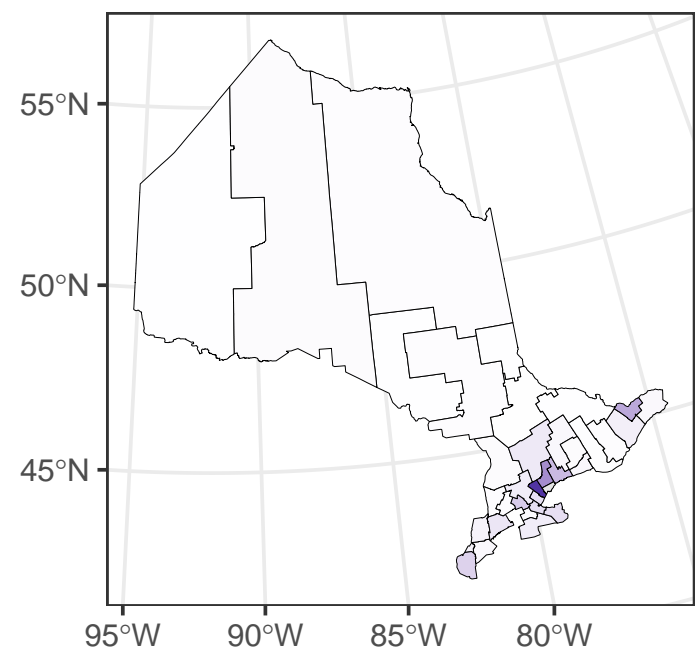

05 July, 2020

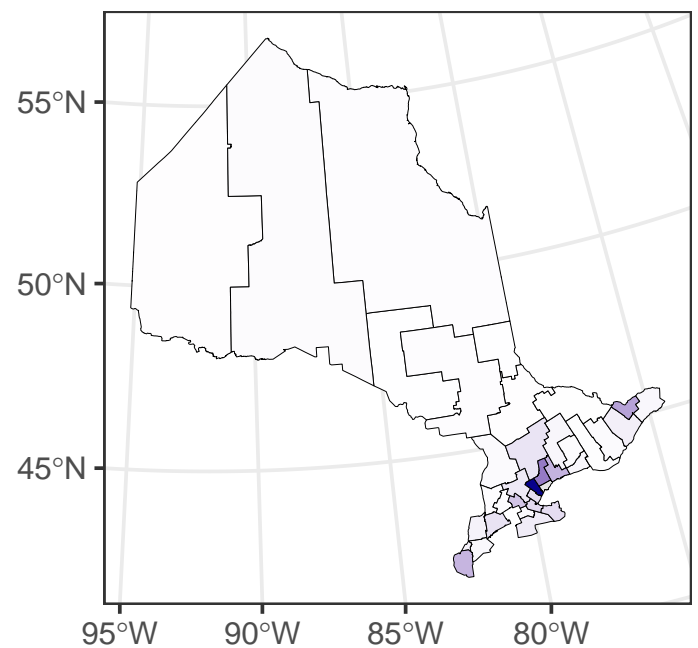

$55^{\circ} \mathrm{N}$

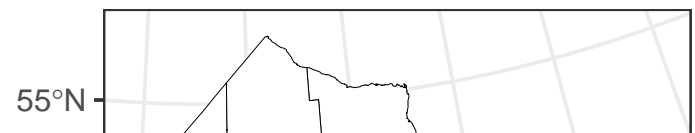

7.18.20156992; this version posted August 26, 2020. The copyright holder for this preprint

$$
\text { able }
$$
granted medRxiv a license to display the preprint in perpetuity.

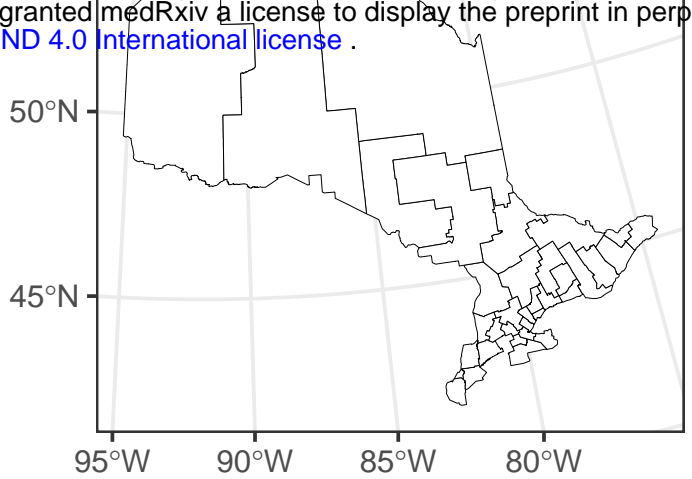

30 April, 2020

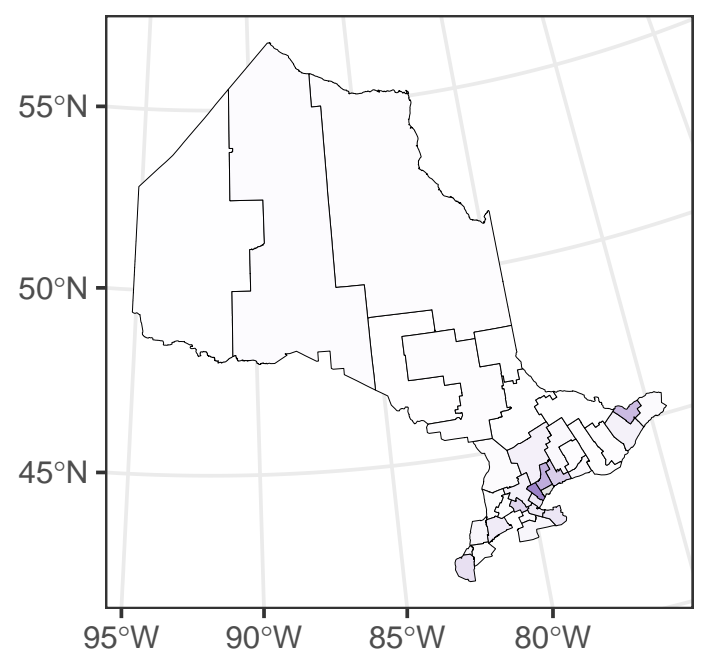

30 June, 2020

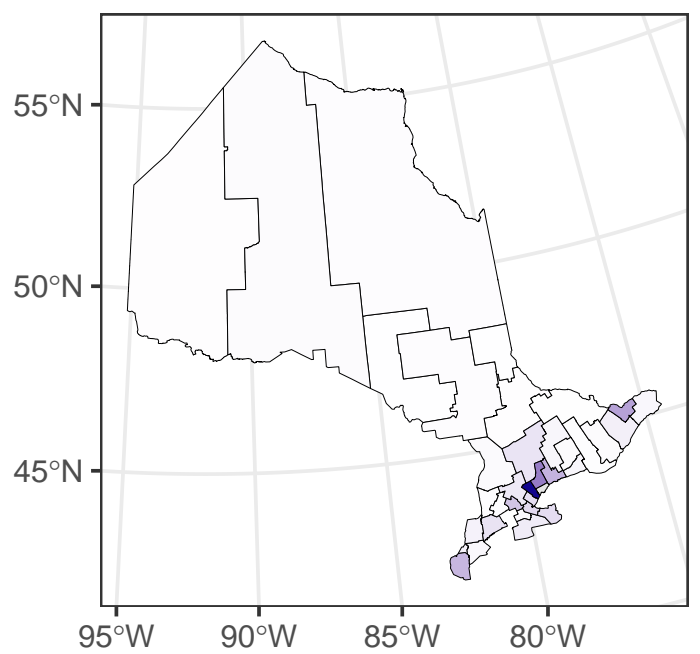




\section{British Columbia}
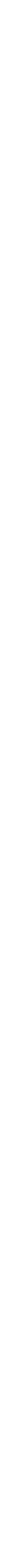
medRxiv preprint doi: https://doi.org/10.1101/2020.07.18.20156992; this version posted August 26, 2020. The copyright holder for this preprint (which Was not certified by peer review) is the author/funder, who has granted meeffixiv-a license to display the preprint in perpetuity.

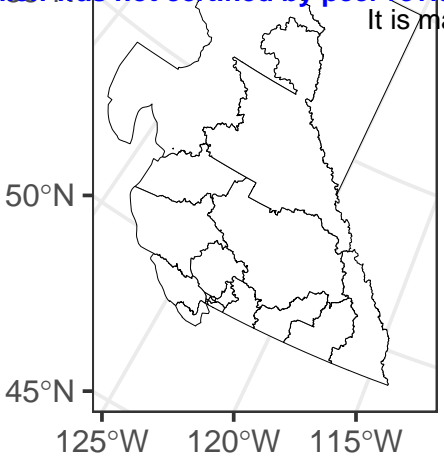

31 March, 2020

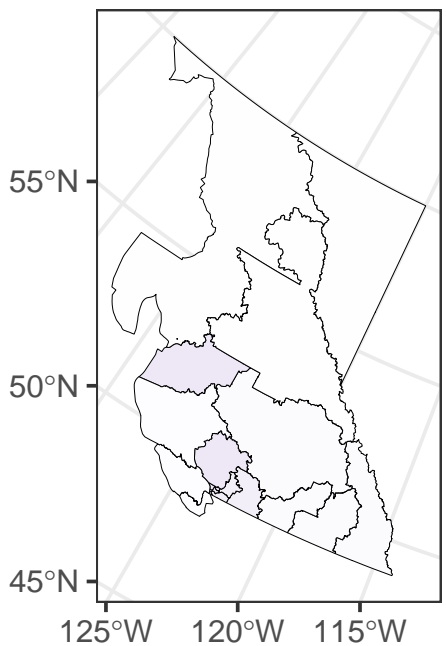

31 May, 2020

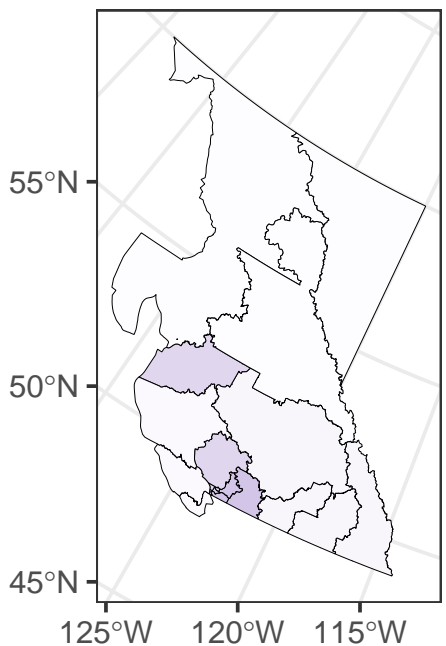

06 July, 2020

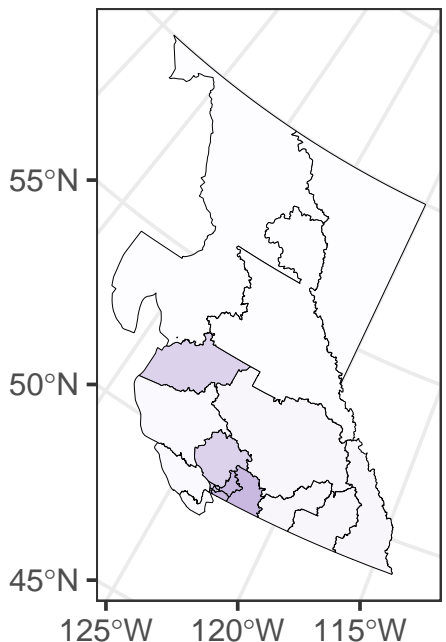

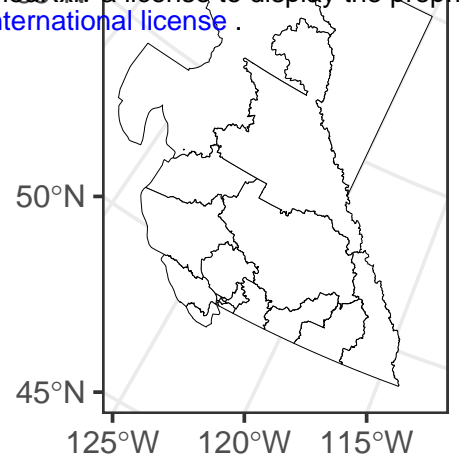

30 April, 2020

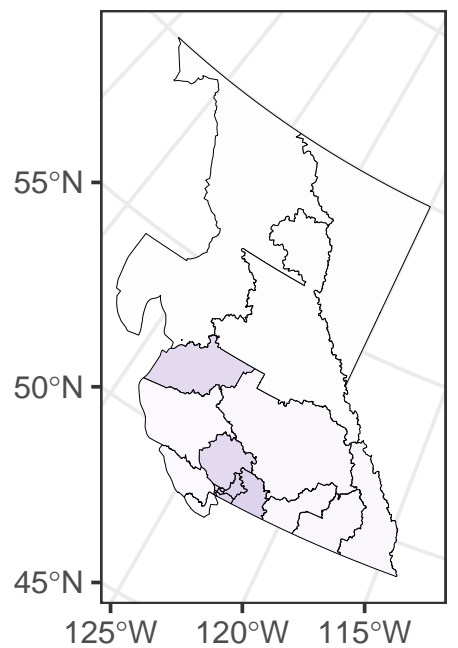

30 June, 2020

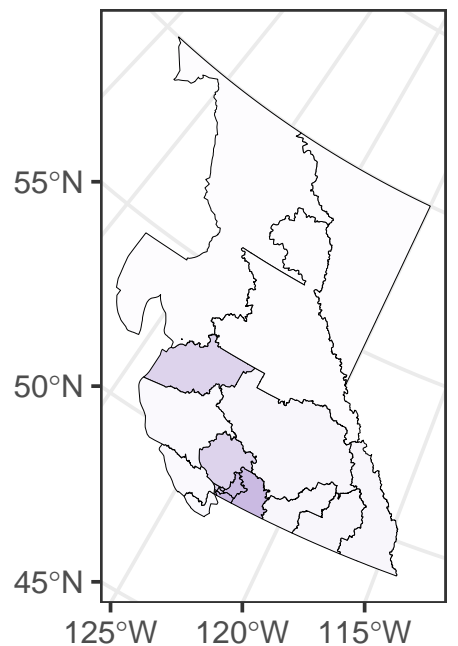

No. of cases

6000

5000

4000

3000

2000

1000

0 

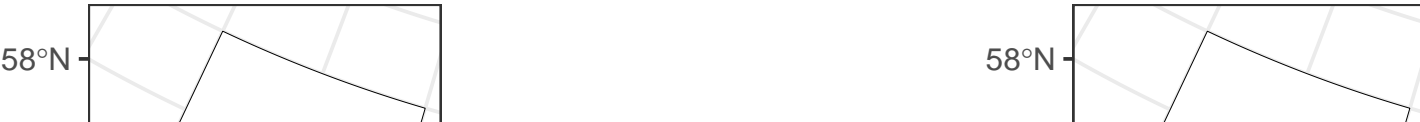

medRxispreprint doi: https://doi.org/10.1101/2020.07.18.20156992; this version posted Avqust 26, 2020. The copyright holder for this preprint (which was not certified by peer review) is the author/funder, who has granted medRxiv a license to display the preprint in perpetuity.

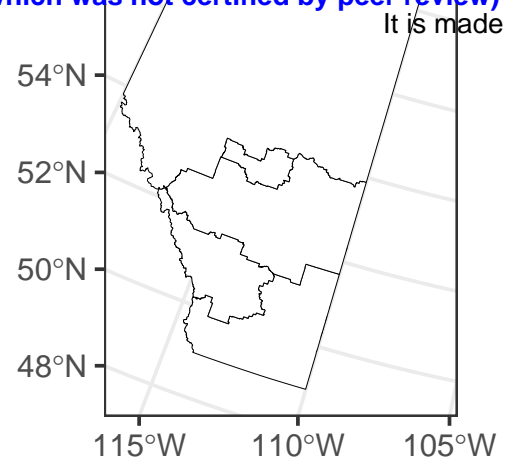

31 March, 2020

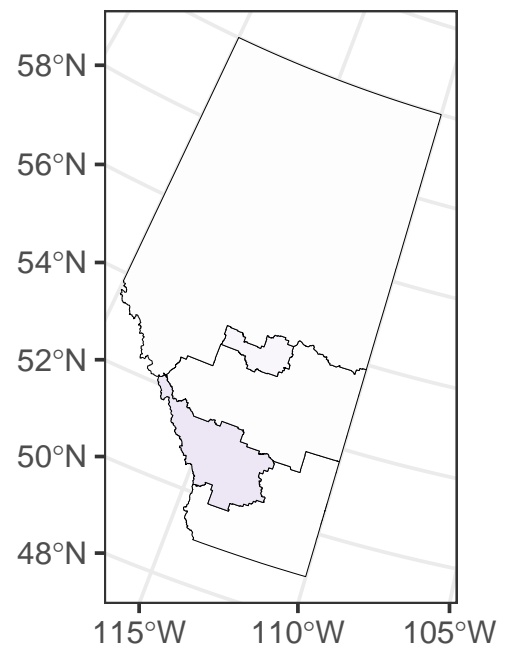

31 May, 2020

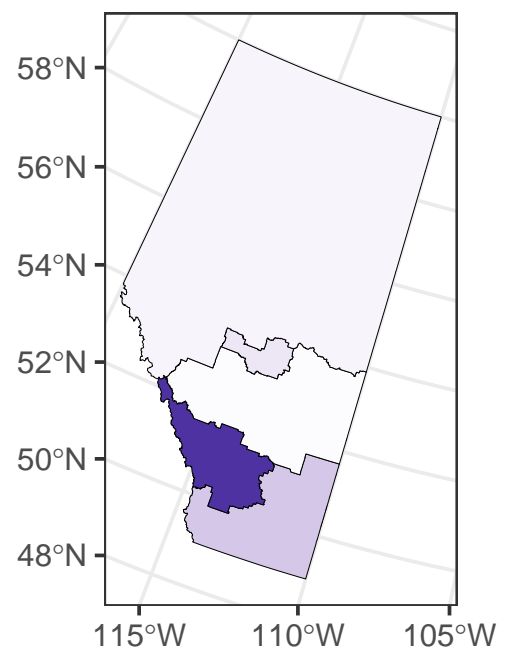

05 July, 2020

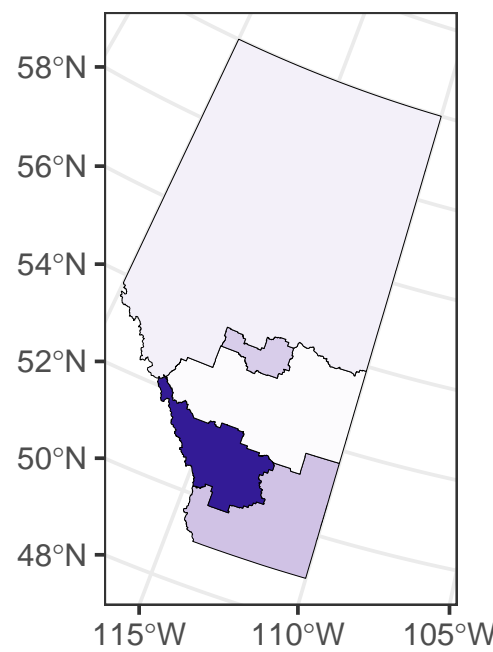

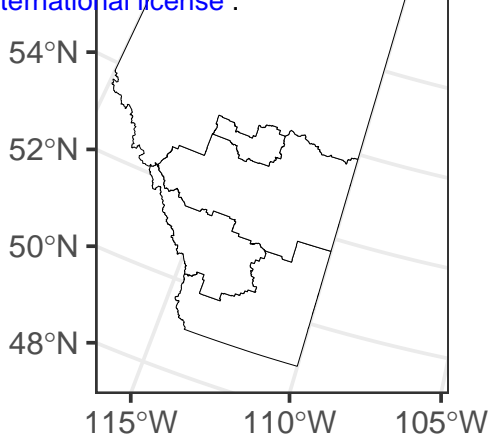

30 April, 2020

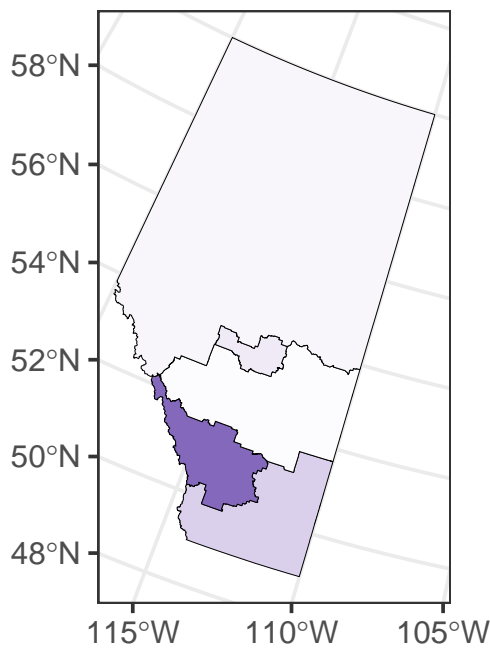

30 June, 2020

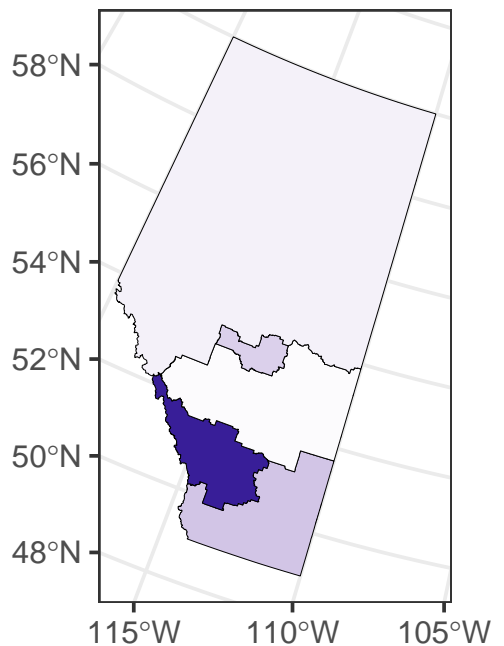

No. of cases

6000

5000

4000

3000

2000

1000 


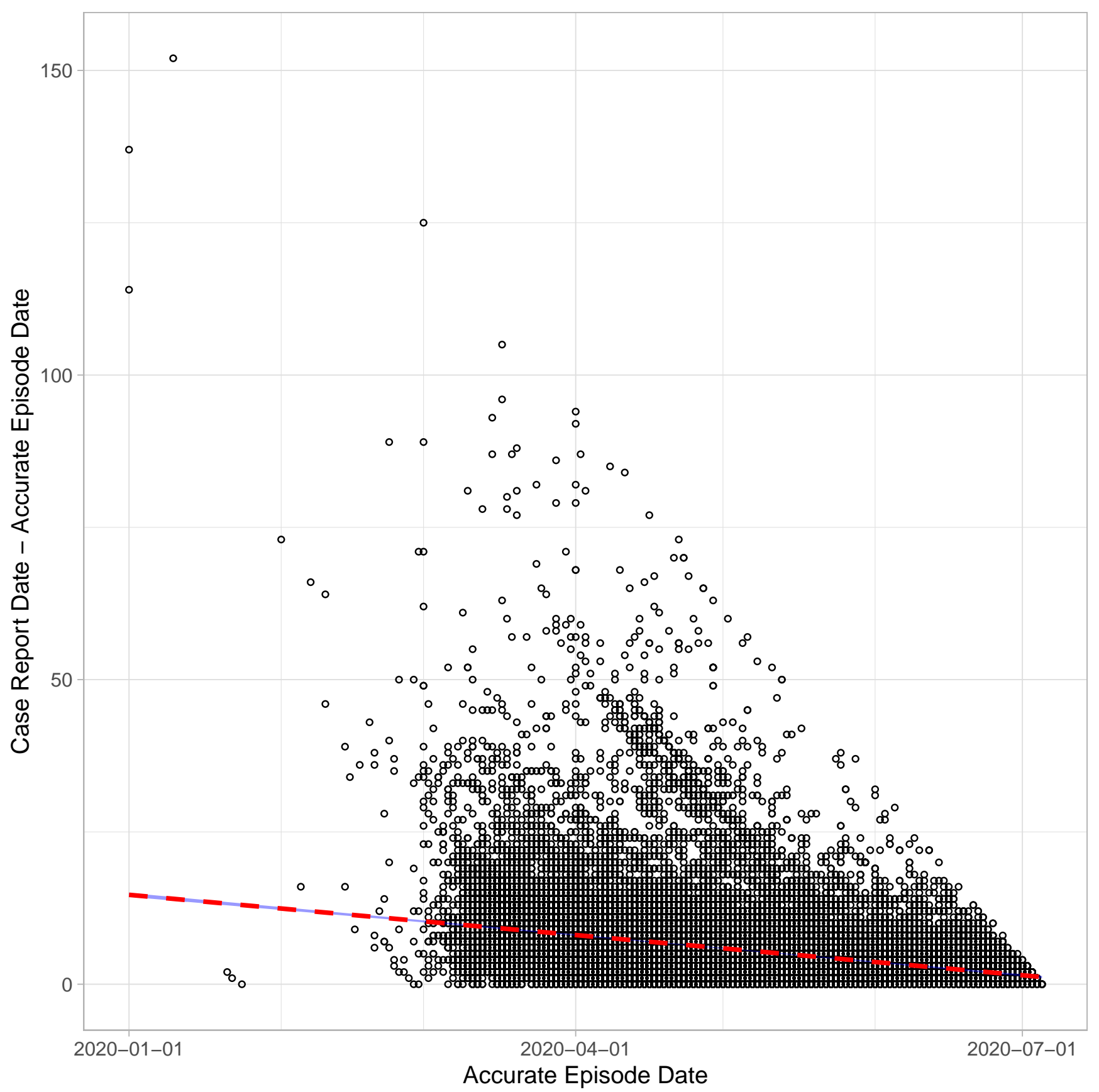




\section{SARS-CoV-2 Transmission in Alberta, British Columbia, and Ontario, Canada, January 1-July 6,}

\section{Online Supplementary Materials}

Authors: Isaac Chun-Hai Fung, PhD; Yuen Wai Hung, PhD; Sylvia K. Ofori, MPH; Kamalich MunizRodriguez, MPH; Po-Ying Lai, MS; Gerardo Chowell, PhD.

Affiliations: Department of Biostatistics, Epidemiology and Environmental Health Sciences, Jiann-Ping Hsu College of Public Health, Georgia Southern University, Statesboro, Georgia, USA (Ms. Ofori, Ms. Muniz-Rodriguez, Dr. Fung); Department of Health Sciences, Wilfrid Laurier University, Waterloo, Ontario, Canada (Dr. Hung); Department of Biostatistics, School of Public Health, Boston University, Boston, Massachusetts, USA (Ms. Lai); Department of Population Health Sciences, School of Public Health, Georgia State University, Atlanta, Georgia, USA (Dr. Chowell)

Correspondence should be addressed to Dr. Isaac Chun-Hai Fung, Department of Biostatistics, Epidemiology and Environmental Health Sciences, Jiann-Ping Hsu College of Public Health, P.O. Box 7989, Georgia Southern University, Statesboro, GA 30460-7989, USA. Tel: +1 912-478-5079. Email: cfung@georgiasouthern.edu

Author Contributions. Dr. Fung is the first and corresponding author. Dr. Hung, Ms. Ofori, Ms. MunizRodriguez and Ms. Lai contributed equally as co-second authors. Dr. Chowell serves as the senior author. 
medRxiv preprint doi: https://doi.org/10.1101/2020.07.18.20156992; this version posted August 26, 2020. The copyright holder for this preprint (which was not certified by peer review) is the author/funder, who has granted medRxiv a license to display the preprint in perpetuity.

It is made available under a CC-BY-NC-ND 4.0 International license .

\section{Instantaneous reproduction number method implemented in R package EpiEstim}

We summarized the instantaneous reproduction number method below, of which detailed description has been made available elsewhere. ${ }^{4,5}$ The instantaneous reproduction number is the ratio between the number of incident cases at time $t$, and the total infectiousness of all the infected individuals at time t: $R_{t}=I_{t} / \Lambda_{t}$, where $\Lambda_{t}=\sum_{s=1}^{t} I_{t-s} w_{s}$. The total infectiousness is the sum of infection incidence up to the previous time point $(t-1)$ weighted by an infectivity function $w_{s}$. The infectivity function is a probability distribution that describes the average infectiousness profile of an individual after being infected, and it is usually represented by the serial interval distribution as an approximation to the generation time distribution. The number of new cases at time $t$ is therefore a Poisson distribution with a mean of $R_{t} \sum_{s=1}^{t} I_{t-s} w_{s}$. Given the reproduction number $R_{t}$, and conditional on the time series of daily new cases, $I_{0}, \ldots, I_{t-1}$, the likelihood of the incidence $I_{t}$ is therefore, $\left(I_{t} \mid I_{0}, \ldots, I_{t-1}, w, R_{t}\right)=\left(R_{t} \Lambda_{t}\right)^{I_{t}} e^{-R_{t} \Lambda_{t}} / I_{t} !$ where $\Lambda_{t}=\sum_{s=1}^{t} I_{t-s} w_{s}$. Therefore, $R_{t}=I_{t} /\left(\sum_{s=1}^{t} I_{t-s} w_{s}\right)$. We can interpret the instantaneous reproduction number as the average number of secondary cases that an infectious person will infect at time $t$, if conditions in previous time points remain the same at time $t$. Given this formulation of the instantaneous reproduction number, $R_{t}$ is highly sensitive to fluctuation in the incidence data. To minimize $R_{t}$ variation, the EpiEstim package allows user to specify a time window over which the $R_{t}$ estimate is assumed to be constant. The window is of size $\tau$ and ends at time $t$. If transmissibility is assumed constant over time from $(t-\tau+1)$ to $t$, and is denoted by a reproduction number, $R_{t, \tau}$, the likelihood of the incidence during the time period, from $I_{(t-\tau+l)}$ to $I_{t}$, conditional on incidence prior to the time period, from $I_{0}$, to $I_{(t-\tau)}$, is found to be: ${ }^{5}$

$$
P\left(I_{t-\tau+1}, \ldots, I_{t} \mid I_{0}, \ldots, I_{t-\tau}, w, R_{t, \tau}\right)=\prod_{s=t-\tau+1}^{t}\left[\left(R_{t, \tau} \Lambda_{s}\right)^{I_{s}} e^{-R_{t, \tau} \Lambda_{s}} / I_{I_{s} !}\right]
$$


medRxiv preprint doi: https://doi.org/10.1101/2020.07.18.20156992; this version posted August 26, 2020. The copyright holder for this preprint (which was not certified by peer review) is the author/funder, who has granted medRxiv a license to display the preprint in perpetuity.

It is made available under a CC-BY-NC-ND 4.0 International license .

The EpiEstim package utilized a Bayesian framework with a Gamma-distributed prior for $R_{t, \tau}$, and the analytical expression of the posterior distribution of $R_{t}$ and estimated its median, the variance and the $95 \%$ credible interval $(\mathrm{CrI}) .^{5}$

Given the small number of cases in January and February and thus wide uncertainty bounds of the $R_{t}$ estimates, we presented $R_{t}$ estimates from March to early July. $R_{t}$ estimates of two respective time windows of 7 days and 14 days, over which the $R_{t}$ estimates is assumed to be constant, were presented with their $95 \% \mathrm{CrI}$, as in Muniz-Rodriguez et al. ${ }^{14}$ As a sensitivity analysis, the 14-day time window provides a more stable estimate as it would not be as responsive to sudden fluctuations in incident case count. We did not use a time window shorter than 7 days because such $R_{t}$ estimate would be very sensitive to daily incidence fluctuation. Furthermore, for surveillance data by date of report (Alberta and British Columbia), weekend effect is common given the 5-day work week, i.e., daily number of cases reported over Saturday and Sunday would be lower than those from Monday to Friday. Therefore, it is reasonable to use time-windows of 7 or 14 days.

Serial interval is assumed to follow a gamma distribution (mean: 4.60 days; standard deviation: 5.55). ${ }^{15}$

Map creation. The health region boundaries shapefile was downloaded at Statistics Canada at https://www150.statcan.gc.ca/n1/pub/82-402-x/2018001/hrbf-flrs-eng.htm. The health regions were based on 2016 Census geographic units. Maps were made in R version 3.5.1 (R Core Team, Vienna, Austria). The boundaries shapefiles are transformed by R packages rnaturalearth (version 0.1.0) and sf (version 0.9.0), merged with the study data by health regions, and presented by R package ggplot2 (version 3.3.0). The maps show the cumulative number of cases and fatal cases on the last day of each month between January 2020 to June 2020, and the last date of the data (5 or 6 July 2020) with non-missing values. 
medRxiv preprint doi: https://doi.org/10.1101/2020.07.18.20156992; this version posted August 26, 2020. The copyright holder for this preprint (which was not certified by peer review) is the author/funder, who has granted medRxiv a license to display the preprint in perpetuity. It is made available under a CC-BY-NC-ND 4.0 International license.

We ran linear regression models to obtain the trend line over time.

\section{a) Time delay in specimen collection}

With (accurate episode date - specimen date) as the outcome variable (y) and accurate episode date as the predictor variable $(\mathrm{x})$, the linear model is:

$y=-0.06627 x+1221.67026$

Given that in R, date is counted from Jan 1, 1970 (when it is "day 0"), for January 1, 2020, $\mathrm{x}=18262, \mathrm{y}=$ 11.41 days; for March 1, 2020, $\mathrm{x}=18322, \mathrm{y}=7.43$ days; for June 21, 2020, $\mathrm{x}=18434, \mathrm{y}=0.0062$ day(s).

\section{b) Time delay in test report}

With (accurate episode date - test report date) as y and accurate episode date as $\mathrm{x}$, the linear model is:

$y=-0.08383 x+1547.21994$

For January 1, 2020, $\mathrm{x}=18262, \mathrm{y}=16.31$ days; for March 1, 2020, $\mathrm{x}=18322, \mathrm{y}=11.29$ days; for July 5, 2020, $x=18448, y=0.72$ day(s).

\section{c) Time delay in case report}

With (accurate episode date - case report date) as $\mathrm{y}$ and accurate episode date as $\mathrm{x}$, the linear model is:

$y=-0.07254+1339.42505$

For January 1, 2020, $\mathrm{x}=18262, \mathrm{y}=14.67$ days; for March 1, 2020, $\mathrm{x}=18322, \mathrm{y}=10.32$ days; for July 5, 2020, $x=18448, y=1.18$ day(s). 
medRxiv preprint doi: https://doi.org/10.1101/2020.07.18.20156992; this version posted August 26, 2020. The copyright holder for this preprint (which was not certified by peer review) is the author/funder, who has granted medRxiv a license to display the preprint in perpetuity.

It is made available under a CC-BY-NC-ND 4.0 International license .

\section{References}

1. Vynnycky E, White RG. An Introduction to Infectious Disease Modelling. Oxford: Oxford University Press; 2010.

2. Gostic KM, McGough L, Baskerville E, et al. Practical considerations for measuring the effective reproductive number, Rt. medRxiv. 2020;2020.06.18.20134858.

3. O'Driscoll M, Harry C, Donnelly CA, Cori A, Dorigatti I. A comparative analysis of statistical methods to estimate the reproduction number in emerging epidemics with implications for the current COVID-19 pandemic. medRxiv. 2020;2020.05.13.20101121.

4. Thompson RN, Stockwin JE, van Gaalen RD, et al. Improved inference of time-varying reproduction numbers during infectious disease outbreaks. Epidemics. 2019;29:100356.

5. Cori A, Ferguson NM, Fraser C, Cauchemez S. A new framework and software to estimate timevarying reproduction numbers during epidemics. Am J Epidemiol. 2013;178(9):1505-1512.

6. Abbott S, Hellewell J, Thompson R, et al. Estimating the time-varying reproduction number of SARS-CoV-2 using national and subnational case counts [version 1; peer review: awaiting peer review]. 2020;5(112).

7. Leung K, Wu JT, Liu D, Leung GM. First-wave COVID-19 transmissibility and severity in China outside Hubei after control measures, and second-wave scenario planning: a modelling impact assessment. Lancet. 2020;395(10233):1382-1393.

8. Cowling BJ, Ali ST, Ng TWY, et al. Impact assessment of non-pharmaceutical interventions against coronavirus disease 2019 and influenza in Hong Kong: an observational study. Lancet Public Health. 2020;5(5):e279-e288.

9. Najafi F, Izadi N, Hashemi-Nazari SS, Khosravi-Shadmani F, Nikbakht R, Shakiba E. Serial interval and time-varying reproduction number estimation for COVID-19 in western Iran. New Microbes New Infect. 2020;36:100715.

10. Zhuang Z, Zhao S, Lin Q, et al. Preliminary estimates of the reproduction number of the coronavirus disease (COVID-19) outbreak in Republic of Korea and Italy by 5 March 2020. Int J Infect Dis. 2020;95:308-310.

11. Moirano G, Schmid M, Barone-Adesi F. Short-Term Effects of Mitigation Measures for the Containment of the COVID-19 Outbreak: An Experience From Northern Italy. Disaster Med Public Health Prep. 2020:1-2.

12. Adegboye OA, Adekunle AI, Gayawan E. Early Transmission Dynamics of Novel Coronavirus (COVID-19) in Nigeria. Int J Environ Res Public Health. 2020;17(9):3054.

13. Scire J, Nadeau S, Vaughan T, et al. Reproductive number of the COVID-19 epidemic in Switzerland with a focus on the Cantons of Basel-Stadt and Basel-Landschaft. Swiss Med Wkly. 2020;150:w20271.

14. Muniz-Rodriguez K, Chowell G, Schwind JS, et al. Time-varying reproduction numbers of COVID-19 in Georgia, USA, March 2-June 14, 2020: comparison of two estimation methods. 2020; https://www.medrxiv.org/content/10.1101/2020.05.19.20107219v2, 2020.05.19.20107219.

15. You C, Deng Y, Hu W, et al. Estimation of the time-varying reproduction number of COVID-19 outbreak in China. Int J Hyg Environ Health. 2020;228:113555.

16. Government of Canada. Coronavirus disease (COVID-19): Outbreak update (as of July 12, 2020). 2020; https://www.canada.ca/en/public-health/services/diseases/2019-novel-coronavirusinfection.html. Accessed July 12, 2020.

17. Government of Ontario. Protecting Ontarians Through Enhanced Testing. 2020; https://files.ontario.ca/moh-covid-19-protecting-ontarians-through-enhanced-testing-en-2020-0529.pdf. Accessed July 12, 2020.

18. Bignami S, Van Assche A. Assessing the burden of COVID-19 in Canada (Version 1). medRxiv 2020; https://www.medrxiv.org/content/medrxiv/early/2020/06/16/2020.06.14.20130815.full.pdf, 2020.06.14.20130815. 
medRxiv preprint doi: https://doi.org/10.1101/2020.07.18.20156992; this version posted August 26, 2020. The copyright holder for this preprint (which was not certified by peer review) is the author/funder, who has granted medRxiv a license to display the preprint in perpetuity.

It is made available under a CC-BY-NC-ND 4.0 International license.

19. Williamson EJ, Walker AJ, Bhaskaran K, et al. OpenSAFELY: factors associated with COVID19 death in 17 million patients. Nature. 2020;DOI: https://doi.org/10.1038/s41586-020-2521-4.

20. Bensadoun E. Nearly half of Canada's COVID-19 deaths linked to long-term care facilities: Tam. Global News 2020; https://globalnews.ca/news/6811726/coronavirus-long-term-care-deathscanada/. Accessed July 13, 2020.

21. Hsu AT, Lane N. Impact of COVID-19 on residents of Canada's long-term care homes - ongoing challenges and policy response. Report in LTCcovid.org, International Long-Term Care Policy Network, CPEC-LSE, 23 April 2020. 2020; https://ltccovid.org/wpcontent/uploads/2020/04/LTC-COVID19-situation-in-Canada-22-April-2020-1.pdf. Accessed July 13, 2020.

22. Brown KA, Jones A, Daneman N, et al. Association Between Nursing Home Crowding and COVID-19 Infection and Mortality in Ontario, Canada (Version 1). medRxiv 2020; https://www.medrxiv.org/content/medrxiv/early/2020/06/23/2020.06.23.20137729.full.pdf, 2020.06.23.20137729.

23. Silverstein WK, Stroud L, Cleghorn GE, Leis JA. First imported case of 2019 novel coronavirus in Canada, presenting as mild pneumonia. Lancet. 2020;395(10225):734.

24. Marchand-Senecal X, Kozak R, Mubareka S, et al. Diagnosis and Management of First Case of COVID-19 in Canada: Lessons applied from SARS. Clin Infect Dis. 2020.

25. Government of Canada. Testing devices for COVID-19: Serological testing devices. 2020; https://www.canada.ca/en/health-canada/services/drugs-health-products/covid19industry/medical-devices/testing/serological.html. Accessed July 13, 2020.

26. Webster P. Canada and COVID-19: learning from SARS. Lancet. 2020;395(10228):936-937.

27. Tsang TK, Wu P, Lin Y, Lau EHY, Leung KSM, Cowling BJ. Effect of changing case definitions for COVID-19 on the epidemic curve and transmission parameters in mainland China: a modelling study. Lancet Public Health. 2020:DOI: 10.1016/S2468-2667(1020)30089-X.

28. Muniz-Rodriguez K, Fung IC-H, Ferdosi SR, et al. Severe Acute Respiratory Syndrome Coronavirus 2 Transmission Potential, Iran, 2020. Emerg Infect Dis. 2020;26(8):DOI: https://doi.org/10.3201/eid2608.200536.

29. Merkley E, Bridgman A, Loewen PJ, Owen T, Ruths D, Zhilin O. A Rare Moment of CrossPartisan Consensus: Elite and Public Response to the COVID-19 Pandemic in Canada. Canadian Journal of Political Science. 2020:1-8.

30. Government of Alberta. Opening soon: Alberta's relaunch strategy (Updated June 2020). 2020; https://open.alberta.ca/dataset/61f54c09-d6d7-4a12-a5be-0bc663a02c31/resource/e158ff14-eab74f24-94f4-b67c3639d0d5/download/covid-19-alberta-relaunch-strategy-2020-06.pdf. Accessed July 13, 2020.

31. Government of Ontario. Reopening Ontario. 2020; https://www.ontario.ca/page/reopeningontario. Accessed July 13, 2020.

32. Government of British Columbia. BC's Restart Plan. 2020; https://www2.gov.bc.ca/gov/content/safety/emergency-preparedness-response-recovery/covid-19provincial-support/bc-restart-plan. Accessed July 13, 2020.

33. CTV News. Tracking every case of COVID-19 in Canada. 2020; https://www.ctvnews.ca/health/coronavirus/tracking-every-case-of-covid-19-in-canada1.4852102. Accessed May 2, 2020.

34. Global News. Timeline: How Canada has changed since coronavirus was declared a pandemic. April 11 2020. . 2020; https://globalnews.ca/news/6800118/pandemic-one-month-timeline/. Accessed May 2, 2020.

35. Public Health Ontario. Coronavirus Disease 2019 (COVID-19) Testing. 2020; https://www.publichealthontario.ca/en/laboratory-services/test-information-index/wuhan-novelcoronavirus. Accessed May 2, 2020.

36. The Global and Mail. Coronavirus March 17: Ontario, Alberta, B.C. declare states of emergency; B.C. closes schools to combat virus spread. 2020; 
medRxiv preprint doi: https://doi.org/10.1101/2020.07.18.20156992; this version posted August 26, 2020. The copyright holder for this preprint (which was not certified by peer review) is the author/funder, who has granted medRxiv a license to display the preprint in perpetuity.

It is made available under a CC-BY-NC-ND 4.0 International license .

https://www.theglobeandmail.com/canada/article-the-latest-on-the-coronavirus-cineplex-closesits-doors-a-quieter-st/. Accessed April 7, 2020.

37. Global News. Alberta closes some non-essential businesses, prevents evictions as 542 COVID-19 cases confirmed. March 27, 2020. 2020; https://globalnews.ca/news/6742251/alberta-healthcoronavirus-covid-19-march-27/. Accessed May 2, 2020.

38. Vogel L. COVID-19: A timeline of Canada's first-wave response. CMAJ News 2020; https://cmajnews.com/2020/06/12/coronavirus-1095847/. Accessed July 13, 2020.

39. Government of Ontario. Reopening Ontario in stages: What can open in Stage 1. 2020; https://www.ontario.ca/page/reopening-ontario-stages\#section-5. Accessed July 13, 2020.

40. Government of Ontario. Reopening Ontario: what's in each stage: What can open in Stage 2. 2020; https://www.ontario.ca/page/reopening-ontario-whats-each-stage\#section-2. Accessed July $13,2020$.

41. Government of British Columbia. Phase 3 - BC's Restart Plan. 2020; https://www2.gov.bc.ca/gov/content/safety/emergency-preparedness-response-recovery/covid-19provincial-support/phase-3. Accessed July 13, 2020. 
Table S1. Timeline of COVID-19-related events in Alberta, British Columbia, and Ontario in 2020.

\begin{tabular}{|c|c|c|}
\hline $\begin{array}{l}\text { Date } \\
\text { (yyyy-mm-dd) }\end{array}$ & Events & Reference \\
\hline $2020-01-25$ & First case of COVID-19 in Canada was reported in Toronto, Ontario. & 33 \\
\hline $2020-01-28$ & First presumptive case of COVID-19 was reported in British Columbia. & 33 \\
\hline $2020-03-05$ & $\begin{array}{l}\text { First case of community transmission in British Columbia was detected through the annual influenza } \\
\text { surveillance program; first presumptive case of travel-related COVID-19 was reported in Alberta. }\end{array}$ & 33 \\
\hline $2020-03-12$ & Ontario ordered public school closure. & 34 \\
\hline 2020-03-15 & First community transmission case was reported in Alberta. & 33 \\
\hline $2020-03-16$ & Change in Public Health Ontario Laboratory testing algorithm of COVID-19. & 35 \\
\hline $2020-03-17$ & $\begin{array}{l}\text { Alberta, British Columbia and Ontario declare states of emergency due to COVID-19, ordered many } \\
\text { businesses, including bars, cinemas and private schools, to close; first COVID-19 related death in Ontario }\end{array}$ & 36 \\
\hline 2020-03-18 & Canada closed border to non-essential travels (including the United States) & 34 \\
\hline 2020-03-19 & Alberta had its first death from COVID-19 & 33 \\
\hline $2020-03-23$ & Ontario ordered mandatory closure of non-essential businesses & 34 \\
\hline $2020-03-26$ & British Columbia placed restrictions on business operations, adopting approaches similar to Québec. & 33 \\
\hline $2020-03-27$ & Alberta ordered closure of all non-essential businesses. & 37 \\
\hline 2020-03-30 & $\begin{array}{l}\text { Ontario's Chief Medical Officer of Health strongly recommended all people over } 70 \text { and those with } \\
\text { compromised immune systems stop going out. Everyone else in the province should stay home as much as } \\
\text { possible to limit the spread of COVID-19. }\end{array}$ & 38 \\
\hline 2020-04-06 & $\begin{array}{l}\text { Canada's Chief Public Health Officer advised Canadians to wear "non-medical" masks to reduce the risk } \\
\text { that asymptomatic people will spread SARS-CoV-2 }\end{array}$ & 38 \\
\hline 2020-04-09 & $\begin{array}{l}\text { Ontario broadened its criteria for testing people with symptoms of COVID-19 to include all hospital } \\
\text { inpatients, long-term care residents, healthcare workers and caregivers, first responders, and residents of } \\
\text { remote or Indigenous communities. } \\
\text { Ontario's Medical Officer of Health also directed that all staff and essential visitors to long-term care homes } \\
\text { must wear personal protective equipment for the entirety of their shift or visit, regardless of whether the } \\
\text { home is experiencing an outbreak. } \\
\text { All residents of British Columbia returning home from abroad would have to submit detailed quarantine } \\
\text { plans or be taken to a federal quarantine site. }\end{array}$ & 38 \\
\hline $2020-04-15$ & $\begin{array}{l}\text { In Ontario, all symptomatic staff and residents of long-term care facilities would be screened, and staff are } \\
\text { no longer allowed to work in more than one home. }\end{array}$ & 38 \\
\hline
\end{tabular}




\begin{tabular}{|c|c|c|}
\hline $2020-05-01$ & $\begin{array}{l}\text { Alberta started slowly reopening provincial parks and golf courses and would resume elective surgeries and } \\
\text { other non-urgent medical services next week. }\end{array}$ & 38 \\
\hline 2020-05-06 & $\begin{array}{l}\text { British Columbia began to reopen its economy, easing lockdown restrictions on some summer sports } \\
\text { activities, retail businesses and hair salons. }\end{array}$ & 38 \\
\hline $2020-05-19$ & $\begin{array}{l}\text { Ontario began to ease pandemic restrictions, gradually resuming scheduled surgeries and reopening some } \\
\text { businesses and services, including retail stores with street entrances, construction, library pickups and some } \\
\text { outdoor sporting competitions. Workplaces could also gradually reopen, but people should work from home } \\
\text { as much as possible. The province also expanded eligibility for testing to include anyone with symptoms of } \\
\text { COVID-19. } \\
\text { British Columbia began to ease pandemic restrictions, allowing various businesses, restaurants, and } \\
\text { childcare to reopen as long as social distancing ( } 2 \mathrm{~m} \text { distance) is maintained. Restaurants could have guests } \\
\text { up to } 6 \text { people in a group. }\end{array}$ & 32,39 \\
\hline $2020-05-20$ & $\begin{array}{l}\text { Ontario recommended that anyone over age two should wear a face covering when riding public transit } \\
\text { unless they have trouble breathing or removing a mask. Provincial officials also said that transit agencies } \\
\text { should erect plexiglass barriers on vehicles, make hand sanitizer available and clear high- touch areas. }\end{array}$ & 38 \\
\hline $2020-05-21$ & $\begin{array}{l}\text { Ontario Premier promised to ramp up testing in the next three to four weeks, but the province was only } \\
\text { completing about half its target of } 16,000 \text { tests per day. }\end{array}$ & 38 \\
\hline $2020-05-27$ & $\begin{array}{l}\text { Ontario extended pandemic restrictions to June } 9 \text { that would have expired on May 29. Under the extended } \\
\text { orders, playgrounds and pools would remain closed, bars and restaurants may only provide takeout and } \\
\text { delivery services, and people may not gather in groups larger than five people. }\end{array}$ & 38 \\
\hline $2020-05-29$ & $\begin{array}{l}\text { Ontario started rolling out an expanded testing strategy for COVID-19, which included testing workers in } \\
\text { key sectors and communities experiencing outbreaks, as well as asymptomatic individuals. Provincial labs } \\
\text { hit testing targets of } 16000 \text { tests a day. }\end{array}$ & 38 \\
\hline 2020-06-01 & $\begin{array}{l}\text { The Canada federal government opened } 38 \text { national parks and } 171 \text { historic sites for hikes and other daytime } \\
\text { activities while camping overnight was not yet permitted. } \\
\text { Ontario reopened provincial parks, drive-in movie theatres and batting cages. } \\
\text { British Columbia reopened schools on a part-time basis. }\end{array}$ & 38 \\
\hline 2020-06-07 & $\begin{array}{l}\text { Alberta began distributing } 20 \text { million non-medical masks at almost } 600 \text { drive-through locations across the } \\
\text { province, including fast food restaurants. While mask use was not mandatory, Alberta's chief medical } \\
\text { officer recommended people wear a non-medical mask when physical distancing is not possible. Calgary } \\
\text { and Edmonton would distribute an additional 500,000 masks through the transit system. }\end{array}$ & 38 \\
\hline $2020-06-12$ & $\begin{array}{l}24 \text { of Ontario's } 34 \text { public health units started second phase of easing pandemic restrictions, and } 10 \text { other } \\
\text { Greater Toronto and Hamilton Area and near the U.S. border would wait until new daily cases in those areas } \\
\text { consistently decrease. } \\
\text { The second phase increased the limit on gatherings to } 10 \text { people and allowed selected personal care services, } \\
\text { outdoor dining, and some outdoor recreational facilities to resume operations. }\end{array}$ & 40 \\
\hline
\end{tabular}




\begin{tabular}{|l|l|l|}
\hline $2020-06-18$ & $\begin{array}{l}\text { Ontario began allowing visitors to long-term care and retirement homes that do not have active cases of } \\
\text { COVID-19. }\end{array}$ & 40 \\
\hline $2020-06-19$ & $\begin{array}{l}\text { Ontario allowed the following public health unit regions to move into stage 2: Durham region health } \\
\text { department, Haldimand-Norfolk health unit, Halton region health department, Hamilton public health } \\
\text { services, Lambton health unit, Niagara region public health department, and York region public health } \\
\text { services }\end{array}$ & 40 \\
\hline $2020-06-24$ & $\begin{array}{l}\text { Ontario allowed Peel public health and Toronto public health units to move into stage 2. } \\
\text { British Columbia entered into phase 3 of reopening, which allowed overnight camping in parks. }\end{array}$ & 40,41 \\
\hline $2020-06-25$ & $\begin{array}{l}\text { Ontario allowed the City of Windsor and all other parts of Essex County to reopen, except the Municipality } \\
\text { of Leamington and the Town of Kingsville }\end{array}$ & 40 \\
\hline $2020-07-01$ & $\begin{array}{l}\text { British Columbia allowed long-term care facility residents to have visit with one designated family member } \\
\text { or friend. }\end{array}$ & 41 \\
\hline
\end{tabular}




\begin{tabular}{|c|c|c|c|}
\hline & Figures & $\begin{array}{l}\text { Date of first case in } \\
2020^{*}\end{array}$ & $\begin{array}{c}\text { Total number of cases in the } \\
\text { datasets } * *\end{array}$ \\
\hline Alberta & $5,6, S 42$ & Mar 6 & 8389 \\
\hline Calgary Zone, AB & S43 & Mar 6 & 5440 \\
\hline Central Zone, $\mathrm{AB}$ & S46 & Mar 11 & 93 \\
\hline Edmonton Zone, AB & S44 & Mar 9 & 1128 \\
\hline North Zone, AB & S47 & Mar 16 & 338 \\
\hline South Zone, AB & $\mathrm{S} 45$ & Mar 16 & 1373 \\
\hline unknown & Not applied & Not applied & 17 \\
\hline British Columbia & 3,4 & Jan 26 & 2978 \\
\hline Fraser Health Authority, BC & S37 & Feb 20 & 1570 \\
\hline Interior Health Authority, BC & S38 & Feb 11 & 203 \\
\hline Northern Health Authority, BC & S39 & Mar 9 & 65 \\
\hline Vancouver Coastal Health Authority, BC & S36 & Jan 26 & 1008 \\
\hline Vancouver Island Health Authority, BC & $\mathrm{S} 40$ & Mar 10 & 132 \\
\hline Ontario & $1,2, \mathrm{~S} 1$ & Jan 1 & 35948 \\
\hline Algoma Public Health Unit, ON & S11 & Mar 8 & 24 \\
\hline Brant County Health Unit, ON & $\mathrm{S} 12$ & Mar 6 & 133 \\
\hline Chatham-Kent Health Unit, ON & S13 & Mar 7 & 161 \\
\hline Durham Region Health Department, ON & S3 & Feb 24 & 1715 \\
\hline Eastern Ontario Health Unit, ON & S14 & Feb 25 & 166 \\
\hline Grey Bruce Health Unit, ON & S15 & Mar 6 & 107 \\
\hline Haldimand-Norfolk Health Unit, ON & S16 & Jan 1 & 430 \\
\hline Haliburton, Kawartha, Pine Ridge District Health Unit, ON & S17 & Mar 2 & 200 \\
\hline Halton Region Health Department, ON & S6 & Mar 2 & 771 \\
\hline Hamilton Public Health Services, ON & S7 & Mar 1 & 845 \\
\hline Hastings and Prince Edward Counties Health Unit, ON & S18 & Feb 1 & 44 \\
\hline Huron Perth District Health Unit, ON & S19 & Mar 7 & 60 \\
\hline Kingston, Frontenac and Lennox \& Addington Public Health, ON & $\mathrm{S} 20$ & Mar 5 & 104 \\
\hline Lambton Public Health, ON & S21 & Mar 6 & 286 \\
\hline Leeds, Grenville and Lanark District Health Unit, ON & S22 & Mar 1 & 354 \\
\hline Middlesex-London Health Unit, ON & S23 & Jan 24 & 630 \\
\hline
\end{tabular}




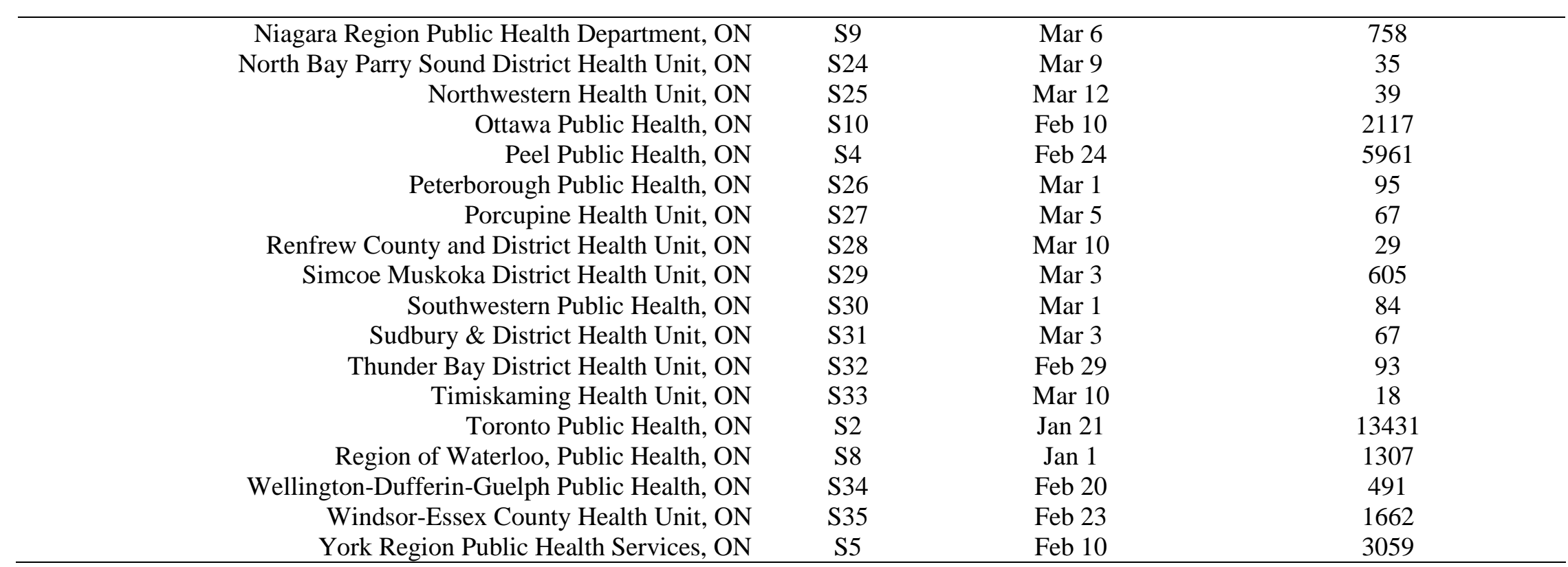


11 Table S3. Cases per 100,000 and incidence rate ratio between Alberta, British Columbia and Ontario by sex (or gender) and age group.

\begin{tabular}{|c|c|c|c|c|c|c|}
\hline & $\begin{array}{l}\text { Cases per } \\
100,000\end{array}$ & & & nce Ra & & \\
\hline Female & $\mathbf{A B}$ & BC & ON & $\mathbf{A B}$ & BC & ON \\
\hline$<20$ & 122.0 & 9.9 & 55.2 & 12.3 & Ref & 5.6 \\
\hline $20-29$ & 208.4 & 55.7 & 265.5 & 21.0 & 5.6 & 26.7 \\
\hline $30-39$ & 225.6 & 75.4 & 243.7 & 22.7 & 7.6 & 24.5 \\
\hline $40-49$ & 271.9 & 68.3 & 286.5 & 27.3 & 6.9 & 28.8 \\
\hline $50-59$ & 201.0 & 79.0 & 310.1 & 20.2 & 7.9 & 31.2 \\
\hline $60-69$ & 129.1 & 44.6 & 225.4 & 13.0 & 4.5 & 22.7 \\
\hline $70-79$ & 119.3 & 57.8 & 227.9 & 12.0 & 5.8 & 22.9 \\
\hline $80+$ & 290.4 & 180.7 & 1027.3 & 29.2 & 18.2 & 103.3 \\
\hline All age groups & 187.3 & 59.9 & 259.9 & 3.1 & Ref & 4.3 \\
\hline Male & $\mathbf{A B}$ & BC & ON & $\mathbf{A B}$ & BC & ON \\
\hline$<20$ & 110.1 & 15.6 & 55.7 & 7.1 & Ref & 3.6 \\
\hline $20-29$ & 211.1 & 47.4 & 261.4 & 13.6 & 3.1 & 16.8 \\
\hline $30-39$ & 254.8 & 67.8 & 262.4 & 16.4 & 4.4 & 16.9 \\
\hline $40-49$ & 315.9 & 67.8 & 260.7 & 20.3 & 4.4 & 16.8 \\
\hline $50-59$ & 216.3 & 71.2 & 251.8 & 13.9 & 4.6 & 16.2 \\
\hline $60-69$ & 139.1 & 59.6 & 249.9 & 8.9 & 3.8 & 16.1 \\
\hline $70-79$ & 112.9 & 70.4 & 264.3 & 7.3 & 4.5 & 17.0 \\
\hline $80+$ & 242.5 & 149.5 & 719.3 & 15.6 & 9.6 & 46.2 \\
\hline All age groups & 196.2 & 57.2 & 229.4 & 3.4 & Ref & 4.0 \\
\hline
\end{tabular}


14 Table S4. Cumulative number of cases and cumulative incidence rate by age and gender in Alberta (N=8,389), as of July 5, 2020.

\begin{tabular}{|c|c|c|c|c|c|c|c|c|c|c|c|}
\hline \multirow[b]{2}{*}{$\begin{array}{l}\text { Age group } \\
\text { (year) }\end{array}$} & \multicolumn{7}{|l|}{ Cases } & \multicolumn{2}{|l|}{$\begin{array}{l}\text { Population } \\
\text { (2019) }\end{array}$} & \multicolumn{2}{|l|}{$\begin{array}{l}\text { Cases per } \\
100,000\end{array}$} \\
\hline & $\mathrm{F}$ & $\mathrm{M}$ & & Unk & & $\begin{array}{l}\% \text { female } \\
\text { by age } \\
\text { group }\end{array}$ & $\begin{array}{l}\text { Total by } \\
\text { age group } \\
(\%)\end{array}$ & $\mathrm{F}$ & $\mathrm{M}$ & $\mathrm{F}$ & $\mathrm{M}$ \\
\hline $0-4$ & 121 & & 123 & & 0 & 49.6 & $244(2.9)$ & 134487 & 139868 & 90.0 & 87.9 \\
\hline$<1$ & 28 & & 27 & & 0 & 50.9 & $55(0.7)$ & No data & No data & $\mathrm{n} / \mathrm{a}$ & $\mathrm{n} / \mathrm{a}$ \\
\hline $1-4$ & 93 & & 96 & & 0 & 49.2 & $189(2.3)$ & No data & No data & $\mathrm{n} / \mathrm{a}$ & $\mathrm{n} / \mathrm{a}$ \\
\hline $5-9$ & 116 & & 120 & & 1 & 48.9 & $237(2.8)$ & 135170 & 141947 & 85.8 & 84.5 \\
\hline $10-19$ & 404 & & 362 & & 1 & 52.7 & $767(9.1)$ & 131345 & 137050 & 307.6 & 264.1 \\
\hline $20-29$ & 604 & & 655 & & 1 & 47.9 & $1260(15.0)$ & 289835 & 310327 & 208.4 & 211.1 \\
\hline $30-39$ & 789 & & 914 & & 0 & 46.3 & $1703(20.3)$ & 349731 & 358741 & 225.6 & 254.8 \\
\hline $40-49$ & 798 & & 955 & & 0 & 45.5 & $1753(20.9)$ & 293475 & 302344 & 271.9 & 315.9 \\
\hline $50-59$ & 552 & & 604 & & 1 & 47.7 & 1157 (13.8) & 274579 & 279245 & 201.0 & 216.3 \\
\hline $60-69$ & 296 & & 316 & & 1 & 48.3 & $613(7.3)$ & 229311 & 227188 & 129.1 & 139.1 \\
\hline $70-79$ & 154 & & 132 & & 0 & 53.8 & $286(3.4)$ & 129090 & 116890 & 119.3 & 112.9 \\
\hline $80+$ & 234 & & 134 & & 0 & 63.6 & $368(4.4)$ & 80569 & 55247 & 290.4 & 242.5 \\
\hline Unk & 0 & & 0 & & 1 & 0 & $1(0.01)$ & $\mathrm{n} / \mathrm{a}$ & $\mathrm{n} / \mathrm{a}$ & $\mathrm{n} / \mathrm{a}$ & $\mathrm{n} / \mathrm{a}$ \\
\hline $\begin{array}{l}\text { All age } \\
\text { groups }\end{array}$ & 4068 & & 4315 & & 6 & 48.5 & $8389(100)$ & 2171882 & 2199434 & 187.3 & 196.2 \\
\hline
\end{tabular}


18 Table S5. Cumulative number of cases and cumulative incidence rate by age and sex in British Columbia (N=2,978), as of July 6, 2020.

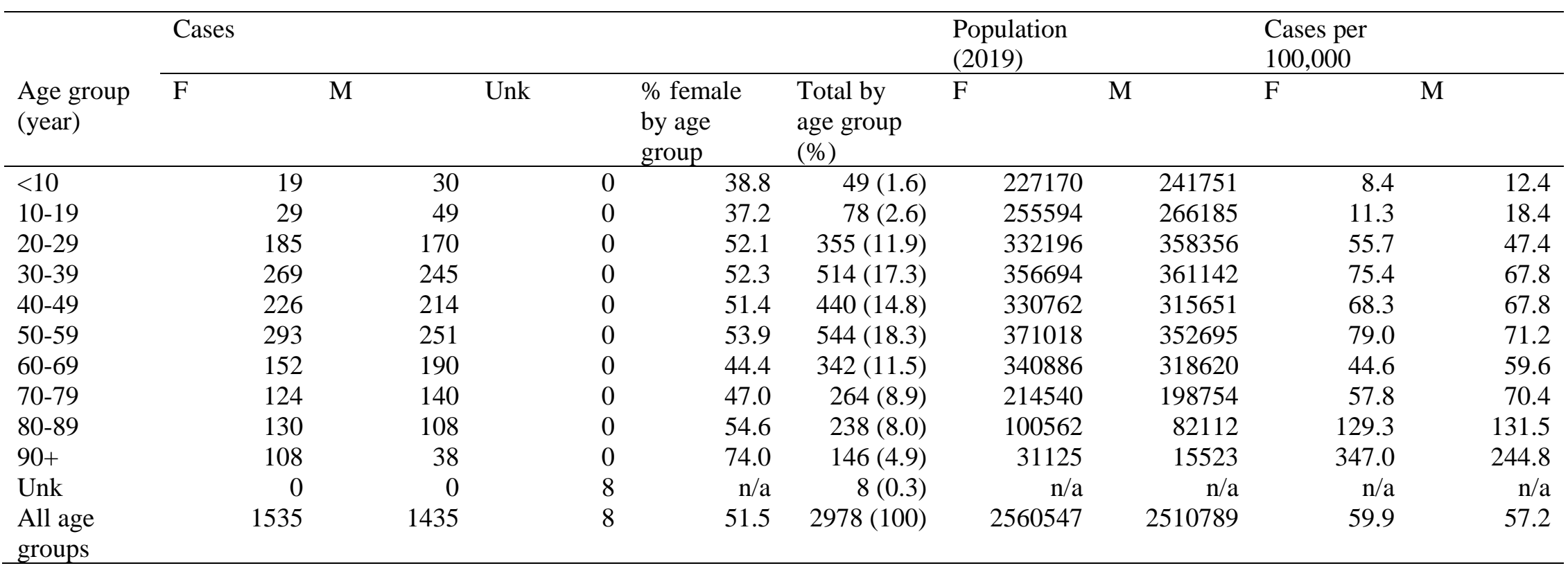

19 F: female; M: male; n/a: not applied; Unk: Unknown.

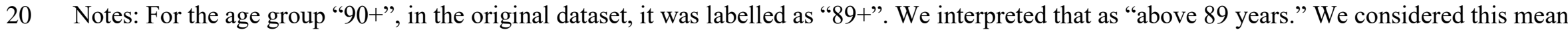

2190 or above, and therefore relabel the age group as " $90+. "$ 
23 Table S6. Cumulative number of cases and cumulative incidence rate by age and gender in Ontario, as of July 5, 2020.

\begin{tabular}{|c|c|c|c|c|c|c|c|c|c|c|c|}
\hline \multirow[b]{2}{*}{$\begin{array}{l}\text { Age group } \\
\text { (year) }\end{array}$} & \multicolumn{7}{|l|}{ Cases } & \multicolumn{2}{|l|}{$\begin{array}{l}\text { Population } \\
(2019)\end{array}$} & \multicolumn{2}{|l|}{$\begin{array}{l}\text { Cases per } \\
100,000\end{array}$} \\
\hline & $\mathrm{F}$ & $\mathrm{M}$ & Other & $\begin{array}{l}\text { Trans- } \\
\text { gender }\end{array}$ & Unk & $\begin{array}{l}\% \text { female by } \\
\text { age group }\end{array}$ & $\begin{array}{l}\text { Total by age } \\
\text { group }(\%)\end{array}$ & $\mathrm{F}$ & $\mathrm{M}$ & $\mathrm{F}$ & $\mathrm{M}$ \\
\hline$<20$ & 848 & 895 & 1 & 1 & 28 & 47.8 & $1773(4.9)$ & 1535170 & 1606523 & 55.24 & 55.71 \\
\hline $20-29$ & 2663 & 2830 & 1 & 1 & 19 & 48.3 & $5514(15.3)$ & 1003139 & 1082560 & 265.47 & 261.42 \\
\hline $30-39$ & 2411 & 2588 & 1 & 3 & 23 & 48.0 & $5026(14.0)$ & 989503 & 986267 & 243.66 & 262.40 \\
\hline $40-49$ & 2726 & 2358 & 2 & 1 & 29 & 53.3 & $5116(14.2)$ & 951581 & 904542 & 286.47 & 260.68 \\
\hline $50-59$ & 3219 & 2572 & 2 & 0 & 18 & 55.4 & $5811(16.2)$ & 1037994 & 1021545 & 310.12 & 251.78 \\
\hline $60-69$ & 2001 & 2071 & 1 & 1 & 17 & 48.9 & 4091 (11.4) & 887750 & 828658 & 225.40 & 249.92 \\
\hline $70-79$ & 1324 & 1342 & 1 & 0 & 23 & 49.2 & $2690(7.5)$ & 580926 & 507818 & 227.91 & 264.27 \\
\hline $80-89$ & 2160 & 1254 & 0 & 1 & 60 & 62.2 & 3475 (9.7) & 295818 & 216615 & 730.18 & 578.91 \\
\hline $90+$ & 1799 & 596 & 0 & 0 & 48 & 73.6 & $2443(6.8)$ & 89561 & 40577 & 2008.69 & 1468.81 \\
\hline Unk & 6 & 3 & 0 & 0 & 0 & 66.7 & $9(0.03)$ & $\mathrm{n} / \mathrm{a}$ & $\mathrm{n} / \mathrm{a}$ & $\mathrm{n} / \mathrm{a}$ & $\mathrm{n} / \mathrm{a}$ \\
\hline $\begin{array}{l}\text { All age } \\
\text { groups }\end{array}$ & 19157 & 16509 & 9 & 8 & 265 & 53.3 & $35948(100)$ & 7371442 & 7195105 & 259.88 & 229.45 \\
\hline
\end{tabular}

24 F: female; M: male; n/a: not applied; Unk: Unknown. 
Table S7. Cases by age, type and clinical outcome in Alberta, as of July 5, 2020.

\begin{tabular}{|c|c|c|c|c|c|c|c|c|c|c|c|c|c|c|c|}
\hline Age & Confirmed & & & & & Probable & & & & & All & & & & \\
\hline & A & $\mathrm{D}$ & $\mathrm{R}$ & $\mathrm{T}$ & $\mathrm{D} /(\mathrm{D}+\mathrm{R})$ & A & $\mathrm{D}$ & $\mathrm{R}$ & $\mathrm{T}$ & $\mathrm{D} /(\mathrm{D}+\mathrm{R})$ & A & D & $\mathrm{R}$ & $\mathrm{T}$ & $\mathrm{D} /(\mathrm{D}+\mathrm{R})$ \\
\hline$<1$ & 5 & 0 & 43 & 48 & $0 \%$ & 0 & 0 & 7 & 7 & $0 \%$ & 5 & 0 & 50 & 55 & $0 \%$ \\
\hline $1-4$ & 17 & 0 & 125 & 142 & $0 \%$ & 1 & 0 & 46 & 47 & $0 \%$ & 18 & 0 & 171 & 189 & $0 \%$ \\
\hline $5-9$ & 24 & 0 & 169 & 193 & $0 \%$ & 1 & 0 & 43 & 44 & $0 \%$ & 25 & 0 & 212 & 237 & $0 \%$ \\
\hline $10-19$ & 66 & 0 & 598 & 664 & $0 \%$ & 2 & 0 & 101 & 103 & $0 \%$ & 68 & 0 & 699 & 767 & $0 \%$ \\
\hline $20-29$ & 127 & 1 & 1023 & 1151 & $0.1 \%$ & 3 & 0 & 106 & 109 & $0 \%$ & 130 & 1 & 1129 & 1260 & $0.1 \%$ \\
\hline $30-39$ & 116 & 1 & 1471 & 1588 & $0.1 \%$ & 4 & 0 & 111 & 115 & $0 \%$ & 120 & 1 & 1582 & 1703 & $0.1 \%$ \\
\hline $40-49$ & 76 & 1 & 1559 & 1636 & $0.1 \%$ & 3 & 0 & 114 & 117 & $0 \%$ & 79 & 1 & 1673 & 1753 & $0.1 \%$ \\
\hline $50-59$ & 59 & 2 & 1009 & 1070 & $0.2 \%$ & 0 & 0 & 87 & 87 & $0 \%$ & 59 & 2 & 1096 & 1157 & $0.2 \%$ \\
\hline $60-69$ & 43 & 10 & 496 & 549 & $2.0 \%$ & 2 & 0 & 62 & 64 & $0 \%$ & 45 & 10 & 558 & 613 & $1.8 \%$ \\
\hline $70-79$ & 29 & 31 & 214 & 274 & $12.7 \%$ & 1 & 0 & 11 & 12 & $0 \%$ & 30 & 31 & 225 & 286 & $12.1 \%$ \\
\hline $80+$ & 28 & 108 & 226 & 362 & $32.3 \%$ & 0 & 1 & 5 & 6 & $16.7 \%$ & 28 & 109 & 231 & 368 & $32.1 \%$ \\
\hline Unknown & 0 & 0 & 1 & 1 & $0 \%$ & 0 & 0 & 0 & 0 & $\mathrm{n} / \mathrm{a}$ & 0 & 0 & 1 & 1 & $0 \%$ \\
\hline All age & 590 & 154 & 6934 & 7678 & $2.2 \%$ & 17 & 1 & 693 & 711 & $0.1 \%$ & 607 & 155 & 7627 & 8389 & $2.0 \%$ \\
\hline
\end{tabular}


29 Table S8. Cases by age and clinical outcome in Ontario, as of July 5, 2020.

\begin{tabular}{lccccc}
\hline Age group (years) & $\mathrm{A}$ & $\mathrm{D}$ & $\mathrm{R}$ & $\mathrm{T}$ & $\mathrm{D} /(\mathrm{D}+\mathrm{R})$ \\
\hline$<20$ & 167 & 1 & 1605 & 1773 & $0.1 \%$ \\
$20-29$ & 452 & 4 & 5058 & 5514 & $0.1 \%$ \\
$30-39$ & 321 & 7 & 4698 & 5026 & $0.1 \%$ \\
$40-49$ & 240 & 21 & 4855 & 5116 & $0.4 \%$ \\
$50-59$ & 265 & 23 & 5459 & 5811 & $1.6 \%$ \\
$60-69$ & 177 & 481 & 3678 & 4091 & $6.0 \%$ \\
$70-79$ & 92 & 976 & 2117 & 2690 & $18.5 \%$ \\
$80-89$ & 71 & 876 & 2428 & 3475 & $28.7 \%$ \\
$90+$ & 47 & 0 & 1520 & 2443 & $36.6 \%$ \\
Unknown & 1 & 8 & 9 & $0 \%$ \\
\hline
\end{tabular}

30 A: Active ("Not Resolved" in the dataset); D: Died ("Fatal" in the dataset); R: Recovered ("Resolved in the dataset); T: Total; D/(D+R):

31 Died/(Died+Recovered); n/a: not applied 
32 Table S9. Cases by age and classification reported in British Columbia, as of July 6, 2020.

\begin{tabular}{lrrr}
\hline Age group (year) & Lab-diagnosed (confirmed) (\% by age group) & Epi-linked (probable) (\% by age group) & Total \\
\hline$<10$ & $48(98.0)$ & $1(2.0)$ & $0(0.0)$ \\
$10-19$ & $78(100)$ & $1(0.3)$ & $79(100)$ \\
$20-29$ & $354(99.7)$ & $2(0.4)$ & $355(100)$ \\
$30-39$ & $512(99.6)$ & $1(0.2)$ & $514(100)$ \\
$40-49$ & $439(99.8)$ & $1(0.2)$ & $440(100)$ \\
$50-59$ & $543(99.8)$ & $1(0.2)$ & $544(100)$ \\
$60-69$ & $341(99.7)$ & $0(0.0)$ & $342(100)$ \\
$70-79$ & $264(100)$ & $1(0.4)$ & $264(100)$ \\
$80-89$ & $237(99.6)$ & $0(0.0)$ & $238(100)$ \\
$90+$ & $146(100)$ & $0(0.0)$ & $146(100)$ \\
Unknown & $8(100)$ & $8(0.3)$ & $8(100)$ \\
All age groups & $2970(99.7)$ & & $2978(100)$ \\
\hline
\end{tabular}


35 Table S10. Among 2391 Ontario cases whose specimen collection (specimen date) happened prior to symptom onset (accurate episode date), as of 36 July 5, 2020.

\begin{tabular}{|c|c|c|c|}
\hline & $\begin{array}{l}\text { Time difference between accurate } \\
\text { episode date and specimen } \\
\text { collection date }\end{array}$ & $\begin{array}{l}\text { Time difference between accurate } \\
\text { episode date and test report date }\end{array}$ & $\begin{array}{l}\text { Time difference between accurate } \\
\text { episode date and case report date }\end{array}$ \\
\hline Minimum & -89 & -33 & 0 \\
\hline $1^{\text {st }}$ quartile & -3 & 0 & 0 \\
\hline Median & -2 & 0 & 0 \\
\hline Mean & -2.716 & 1.028 & 1.127 \\
\hline $3^{\text {rd }}$ quartile & -1 & 1 & 1 \\
\hline Maximum & -1 & 55 & 38 \\
\hline NA & $\mathrm{n}=0$ & $\mathrm{n}=8 *$ & $\mathrm{n}=0$ \\
\hline
\end{tabular}

37 *All 8 case-patients whose test reported date is NA, developed symptoms after the date of specimen collection. Perhaps their tests were not 38 positive. But they were reported as cases on or after the date of their symptom onset. 
41 Table S11. Among 2391 Ontario cases whose specimen collection (specimen date) happened prior to symptom onset (accurate episode date), as of 42 July 5, 2020.

\begin{tabular}{|c|c|c|c|c|c|c|c|}
\hline $\begin{array}{l}\text { Age group } \\
\text { (years) }\end{array}$ & Gender & Travel & Close Contact & Outbreak & No Epi-link & $\begin{array}{l}\text { No Info- } \\
\text { Missing }\end{array}$ & $\begin{array}{l}\text { No Info- } \\
\text { Unknown }\end{array}$ \\
\hline \multirow[t]{3}{*}{$<20$} & $\mathrm{~F}$ & 1 & 44 & 3 & 3 & 3 & 0 \\
\hline & M & 0 & 51 & 6 & 7 & 0 & 0 \\
\hline & Unknown & 0 & 0 & 0 & 0 & 0 & 0 \\
\hline \multirow[t]{3}{*}{$20 \mathrm{~s}$} & $\mathrm{~F}$ & 4 & 49 & 65 & 16 & 2 & 4 \\
\hline & M & 2 & 59 & 53 & 13 & 2 & 0 \\
\hline & Unknown & 0 & 0 & 1 & 0 & 0 & 0 \\
\hline \multirow[t]{3}{*}{$30 \mathrm{~s}$} & $\mathrm{~F}$ & 0 & 47 & 47 & 11 & 1 & 5 \\
\hline & M & 2 & 53 & 79 & 11 & 0 & 5 \\
\hline & Unknown & 0 & 0 & 0 & 0 & 0 & 0 \\
\hline \multirow[t]{3}{*}{$40 \mathrm{~s}$} & $\mathrm{~F}$ & 2 & 55 & 92 & 21 & 3 & 3 \\
\hline & M & 1 & 37 & 53 & 21 & 1 & 2 \\
\hline & Unknown & 0 & 0 & 1 & 0 & 0 & 0 \\
\hline \multirow[t]{3}{*}{$50 \mathrm{~s}$} & $\mathrm{~F}$ & 1 & 49 & 105 & 16 & 3 & 5 \\
\hline & $\mathrm{M}$ & 4 & 53 & 54 & 29 & 1 & 5 \\
\hline & Unknown & 0 & 0 & 1 & 0 & 0 & 0 \\
\hline \multirow[t]{3}{*}{$60 \mathrm{~s}$} & $\mathrm{~F}$ & 4 & 42 & 70 & 12 & 2 & 3 \\
\hline & $\mathrm{M}$ & 1 & 31 & 52 & 17 & 3 & 2 \\
\hline & Unknown & 0 & 0 & 0 & 0 & 0 & 0 \\
\hline \multirow[t]{3}{*}{$70 \mathrm{~s}$} & $\mathrm{~F}$ & 2 & 15 & 76 & 5 & 1 & 1 \\
\hline & M & 2 & 15 & 77 & 13 & 1 & 0 \\
\hline & Unknown & 0 & 0 & 2 & 0 & 0 & 0 \\
\hline \multirow[t]{3}{*}{$80 \mathrm{~s}$} & $\mathrm{~F}$ & 0 & 10 & 209 & 6 & 0 & 0 \\
\hline & M & 2 & 5 & 109 & 6 & 1 & 0 \\
\hline & Unknown & 0 & 0 & 4 & 0 & 0 & 0 \\
\hline \multirow[t]{3}{*}{$90 \mathrm{~s}$} & $\mathrm{~F}$ & 0 & 3 & 231 & 0 & 0 & 1 \\
\hline & M & 0 & 1 & 77 & 4 & 0 & 0 \\
\hline & Unknown & 0 & 0 & 6 & 0 & 0 & 0 \\
\hline \multirow[t]{4}{*}{ All age groups } & $\mathrm{F}$ & 14 & 314 & 898 & 90 & 15 & 22 \\
\hline & M & 14 & 305 & 560 & 121 & 9 & 14 \\
\hline & Unknown & 0 & 0 & 15 & 0 & 0 & 0 \\
\hline & All & 28 & 619 & 1473 & 211 & 24 & 36 \\
\hline
\end{tabular}


medRxiv preprint doi: https://doi.org/10.1101/2020.07.18.20156992; this version posted August 26, 2020. The copyright holder for this preprint (which was not certified by peer review) is the author/funder, who has granted medRxiv a license to display the preprint in perpetuity.

It is made available under a CC-BY-NC-ND 4.0 International license .

44

45

46

47

\section{Supplementary Figure legends}

Figure S1. Map of cumulative number of deaths in Ontario by public health unit by the end of month and on July 6, 2020.

Figure S2. The epidemic trajectory of coronavirus disease 2019 in Toronto Public Health, Ontario, January 1-July 5, 2020: Upper panel: Daily number of new imported and local cases by date of symptom onset (aka accurate episode date) (upper panel); Rt with a 1-week window (middle panel); Rt with a 2week window (lower panel).

Figure S3. The epidemic trajectory of coronavirus disease 2019 in Durham Region Health Department, Ontario, January 1-July 5, 2020: Upper panel: Daily number of new imported and local cases by date of symptom onset (aka accurate episode date) (upper panel); Rt with a 1-week window (middle panel); Rt with a 2-week window (lower panel).

Figure S4. The epidemic trajectory of coronavirus disease 2019 in Peel Public Health, Ontario, January 1-July 5, 2020: Upper panel: Daily number of new imported and local cases by date of symptom onset (aka accurate episode date) (upper panel); Rt with a 1-week window (middle panel); Rt with a 2-week window (lower panel).

Figure S5. The epidemic trajectory of coronavirus disease 2019 in York Region Public Health Services, Ontario, January 1-July 5, 2020: Upper panel: Daily number of new imported and local cases by date of symptom onset (aka accurate episode date) (upper panel); Rt with a 1-week window (middle panel); Rt with a 2-week window (lower panel).

Figure S6. The epidemic trajectory of coronavirus disease 2019 in Halton Public Health Services,

64 Ontario, January 1-July 5, 2020: Upper panel: Daily number of new imported and local cases by date of 65 symptom onset (aka accurate episode date) (upper panel); Rt with a 1-week window (middle panel); Rt with a 2-week window (lower panel). 
medRxiv preprint doi: https://doi.org/10.1101/2020.07.18.20156992; this version posted August 26, 2020. The copyright holder for this preprint (which was not certified by peer review) is the author/funder, who has granted medRxiv a license to display the preprint in perpetuity.

It is made available under a CC-BY-NC-ND 4.0 International license .

Figure S7. The epidemic trajectory of coronavirus disease 2019 in Hamilton Public Health Services, Ontario, January 1-July 5, 2020: Upper panel: Daily number of new imported and local cases by date of symptom onset (aka accurate episode date) (upper panel); Rt with a 1-week window (middle panel); Rt with a 2-week window (lower panel).

Figure S8. The epidemic trajectory of coronavirus disease 2019 in Region of Waterloo, Public Health Services, Ontario, January 1-July 5, 2020: Upper panel: Daily number of new imported and local cases by date of symptom onset (aka accurate episode date) (upper panel); Rt with a 1-week window (middle panel); Rt with a 2-week window (lower panel).

Figure S9. The epidemic trajectory of coronavirus disease 2019 in Niagara Region Public Health Department, Ontario, January 1-July 5, 2020: Upper panel: Daily number of new imported and local cases by date of symptom onset (aka accurate episode date) (upper panel); Rt with a 1-week window (middle panel); Rt with a 2-week window (lower panel). North Bay Parry Sound District Health Unit

Figure S10. The epidemic trajectory of coronavirus disease 2019 in Ottawa Public Health Services, Ontario, January 1-July 5, 2020: Upper panel: Daily number of new imported and local cases by date of symptom onset (aka accurate episode date) (upper panel); Rt with a 1-week window (middle panel); Rt with a 2-week window (lower panel).

Figure S11. The epidemic trajectory of coronavirus disease 2019 in Algoma Public Health Unit, Ontario, January 1-July 5, 2020: Upper panel: Daily number of new imported and local cases by date of symptom onset (aka accurate episode date) (upper panel); Rt with a 1-week window (middle panel); Rt with a 2week window (lower panel). Figure S12. The epidemic trajectory of coronavirus disease 2019 in Brant County Health Unit, Ontario, January 1-July 5, 2020: Upper panel: Daily number of new imported and local cases by date of symptom onset (aka accurate episode date) (upper panel); Rt with a 1-week window (middle panel); Rt with a 2week window (lower panel). 
medRxiv preprint doi: https://doi.org/10.1101/2020.07.18.20156992; this version posted August 26, 2020. The copyright holder for this preprint (which was not certified by peer review) is the author/funder, who has granted medRxiv a license to display the preprint in perpetuity.

It is made available under a CC-BY-NC-ND 4.0 International license .

91 Figure S13. The epidemic trajectory of coronavirus disease 2019 in Chatham-Kent Health Unit, Ontario,

92 January 1-July 5, 2020: Upper panel: Daily number of new imported and local cases by date of symptom

93 onset (aka accurate episode date) (upper panel); Rt with a 1-week window (middle panel); Rt with a 2-

94 week window (lower panel).

95 Figure S14. The epidemic trajectory of coronavirus disease 2019 in Eastern Ontario Health Unit, Ontario,

96 January 1-July 5, 2020: Upper panel: Daily number of new imported and local cases by date of symptom

97 onset (aka accurate episode date) (upper panel); Rt with a 1-week window (middle panel); Rt with a 2-

98 week window (lower panel).

99 Figure S15. The epidemic trajectory of coronavirus disease 2019 in Grey Bruce Health Unit, Ontario,

100 January 1-July 5, 2020: Upper panel: Daily number of new imported and local cases by date of symptom

101 onset (aka accurate episode date) (upper panel); Rt with a 1-week window (middle panel); Rt with a 2-

102 week window (lower panel).

103 Figure S16. The epidemic trajectory of coronavirus disease 2019 in Haldimand-Norfolk Health Unit,

104 Ontario, January 1-July 5, 2020: Upper panel: Daily number of new imported and local cases by date of

105 symptom onset (aka accurate episode date) (upper panel); Rt with a 1-week window (middle panel); Rt

106 with a 2-week window (lower panel).

107 Figure S17. The epidemic trajectory of coronavirus disease 2019 in Haliburton, Kawartha, Pine Ridge

108 District Health Unit, Ontario, January 1-July 5, 2020: Upper panel: Daily number of new imported and

109 local cases by date of symptom onset (aka accurate episode date) (upper panel); Rt with a 1-week window

110 (middle panel); Rt with a 2-week window (lower panel).

111 Figure S18. The epidemic trajectory of coronavirus disease 2019 in Hastings and Prince Edward

112 Counties Health Unit, Ontario, January 1-July 5, 2020: Upper panel: Daily number of new imported and

113 local cases by date of symptom onset (aka accurate episode date) (upper panel); Rt with a 1-week window

114 (middle panel); Rt with a 2-week window (lower panel). 
medRxiv preprint doi: https://doi.org/10.1101/2020.07.18.20156992; this version posted August 26, 2020. The copyright holder for this preprint (which was not certified by peer review) is the author/funder, who has granted medRxiv a license to display the preprint in perpetuity.

It is made available under a CC-BY-NC-ND 4.0 International license .

115 Figure S19. The epidemic trajectory of coronavirus disease 2019 in Huron Perth District Health Unit,

116 Ontario, January 1-July 5, 2020: Upper panel: Daily number of new imported and local cases by date of

117 symptom onset (aka accurate episode date) (upper panel); Rt with a 1-week window (middle panel); Rt

118 with a 2-week window (lower panel).

119 Figure S20. The epidemic trajectory of coronavirus disease 2019 in Kingston, Frontenac and Lennox \& 120 Addington Public Health, Ontario, January 1-July 5, 2020: Upper panel: Daily number of new imported 121 and local cases by date of symptom onset (aka accurate episode date) (upper panel); Rt with a 1-week 122 window (middle panel); Rt with a 2-week window (lower panel).

Figure S21. The epidemic trajectory of coronavirus disease 2019 in Lambton Public Health, Ontario,

124 January 1-July 5, 2020: Upper panel: Daily number of new imported and local cases by date of symptom 125 onset (aka accurate episode date) (upper panel); Rt with a 1-week window (middle panel); Rt with a 2126 week window (lower panel).

127 Figure S22. The epidemic trajectory of coronavirus disease 2019 in Leeds, Grenville and Lanark District 128 Health Unit, Ontario, January 1-July 5, 2020: Upper panel: Daily number of new imported and local cases 129 by date of symptom onset (aka accurate episode date) (upper panel); Rt with a 1-week window (middle 130 panel); Rt with a 2-week window (lower panel).

Figure S23. The epidemic trajectory of coronavirus disease 2019 in Middlesex-London Health Unit,

132 Ontario, January 1-July 5, 2020: Upper panel: Daily number of new imported and local cases by date of 133 symptom onset (aka accurate episode date) (upper panel); Rt with a 1-week window (middle panel); Rt 134 with a 2-week window (lower panel).

135 Figure S24. The epidemic trajectory of coronavirus disease 2019 in North Bay Parry Sound District 136 Health Unit, Ontario, January 1-July 5, 2020: Upper panel: Daily number of new imported and local cases 137 by date of symptom onset (aka accurate episode date) (upper panel); Rt with a 1-week window (middle 138 panel); Rt with a 2-week window (lower panel). 
medRxiv preprint doi: https://doi.org/10.1101/2020.07.18.20156992; this version posted August 26, 2020. The copyright holder for this preprint (which was not certified by peer review) is the author/funder, who has granted medRxiv a license to display the preprint in perpetuity.

It is made available under a CC-BY-NC-ND 4.0 International license .

Figure S25. The epidemic trajectory of coronavirus disease 2019 in Northwestern Health Unit, Ontario,

140 January 1-July 5, 2020: Upper panel: Daily number of new imported and local cases by date of symptom

141 onset (aka accurate episode date) (upper panel); Rt with a 1-week window (middle panel); Rt with a 2-

142 week window (lower panel).

143 Figure S26. The epidemic trajectory of coronavirus disease 2019 in Peterborough Public Health, Ontario,

144 January 1-July 5, 2020: Upper panel: Daily number of new imported and local cases by date of symptom

145 onset (aka accurate episode date) (upper panel); Rt with a 1-week window (middle panel); Rt with a 2-

146 week window (lower panel).

147 Figure S27. The epidemic trajectory of coronavirus disease 2019 in Porcupine Health Unit, Ontario,

148 January 1-July 5, 2020: Upper panel: Daily number of new imported and local cases by date of symptom

149 onset (aka accurate episode date) (upper panel); Rt with a 1-week window (middle panel); Rt with a 2-

150 week window (lower panel).

151 Figure S28. The epidemic trajectory of coronavirus disease 2019 in Renfrew County and District Health

152 Unit, Ontario, January 1-July 5, 2020: Upper panel: Daily number of new imported and local cases by

153 date of symptom onset (aka accurate episode date) (upper panel); Rt with a 1-week window (middle

154 panel); Rt with a 2-week window (lower panel).

Figure S29. The epidemic trajectory of coronavirus disease 2019 in Simcoe Muskoka District Health Unit, Ontario, January 1-July 5, 2020: Upper panel: Daily number of new imported and local cases by

157 date of symptom onset (aka accurate episode date) (upper panel); Rt with a 1-week window (middle

158 panel); Rt with a 2-week window (lower panel).

159 Figure S30. The epidemic trajectory of coronavirus disease 2019 in Southwestern Health Unit, Ontario,

160 January 1-July 5, 2020: Upper panel: Daily number of new imported and local cases by date of symptom

161 onset (aka accurate episode date) (upper panel); Rt with a 1-week window (middle panel); Rt with a 2-

162 week window (lower panel). 
medRxiv preprint doi: https://doi.org/10.1101/2020.07.18.20156992; this version posted August 26, 2020. The copyright holder for this preprint (which was not certified by peer review) is the author/funder, who has granted medRxiv a license to display the preprint in perpetuity.

It is made available under a CC-BY-NC-ND 4.0 International license .

163

164

165

166

167

168

169

170

171

172

173

174

175

176

177

178

Figure S31. The epidemic trajectory of coronavirus disease 2019 in Sudbury \& Districts Health Unit, Ontario, January 1-July 5, 2020: Upper panel: Daily number of new imported and local cases by date of symptom onset (aka accurate episode date) (upper panel); Rt with a 1-week window (middle panel); Rt with a 2-week window (lower panel).

Figure S32. The epidemic trajectory of coronavirus disease 2019 in Thunder Bay District Health Unit, Ontario, January 1-July 5, 2020: Upper panel: Daily number of new imported and local cases by date of symptom onset (aka accurate episode date) (upper panel); Rt with a 1-week window (middle panel); Rt with a 2-week window (lower panel).

Figure S33. The epidemic trajectory of coronavirus disease 2019 in Timiskaming Health Unit, Ontario, January 1-July 5, 2020: Upper panel: Daily number of new imported and local cases by date of symptom onset (aka accurate episode date) (upper panel); Rt with a 1-week window (middle panel); Rt with a 2week window (lower panel).

Figure S34. The epidemic trajectory of coronavirus disease 2019 in Windsor-Dufferin-Guelph Public Health, Ontario, January 1-July 5, 2020: Upper panel: Daily number of new imported and local cases by date of symptom onset (aka accurate episode date) (upper panel); Rt with a 1-week window (middle panel); Rt with a 2-week window (lower panel).

Figure S35. The epidemic trajectory of coronavirus disease 2019 in Windsor-Dufferin-Guelph Public Health, Ontario, January 1-July 5, 2020: Upper panel: Daily number of new imported and local cases by date of symptom onset (aka accurate episode date) (upper panel); Rt with a 1-week window (middle panel); Rt with a 2-week window (lower panel).

Figure S36. The epidemic trajectory of coronavirus disease 2019 in Vancouver Coastal Health Authority, British Columbia, January 1-July 6, 2020: Daily number of new cases by date of report (upper panel); $R_{t}$ with a 1-week window (middle panel); $R_{t}$ with a 2-week window (lower panel). 
medRxiv preprint doi: https://doi.org/10.1101/2020.07.18.20156992; this version posted August 26, 2020. The copyright holder for this preprint (which was not certified by peer review) is the author/funder, who has granted medRxiv a license to display the preprint in perpetuity.

It is made available under a CC-BY-NC-ND 4.0 International license .

186

187

188

189

190

191

192

193

Figure S37. The epidemic trajectory of coronavirus disease 2019 in Fraser Health Authority, British Columbia, January 1-July 6, 2020: Daily number of new cases by date of report (upper panel); $R_{t}$ with a 1-week window (middle panel); $R_{t}$ with a 2-week window (lower panel).

Figure S38. The epidemic trajectory of coronavirus disease 2019 in Interior Health Authority, British Columbia, January 1-July 6, 2020: Daily number of new cases by date of report (upper panel); $R_{t}$ with a 1-week window (middle panel); $R_{t}$ with a 2-week window (lower panel).

Figure S39. The epidemic trajectory of coronavirus disease 2019 in Northern Health Authority, British Columbia, January 1-July 6, 2020: Daily number of new cases by date of report (upper panel); $R_{t}$ with a 1-week window (middle panel); $R_{t}$ with a 2-week window (lower panel).

Figure S40. The epidemic trajectory of coronavirus disease 2019 in Vancouver Island Health Authority, British Columbia, January 1-July 6, 2020: Daily number of new cases by date of report (upper panel); $R_{t}$ with a 1-week window (middle panel); $R_{t}$ with a 2-week window (lower panel).

Figure S41. Sensitivity analysis (lab-diagnosed cases only): The epidemic trajectory of coronavirus disease 2019 in British Columbia, 2020: Daily number of new lab-diagnosed cases by date of report (upper panel), $R_{t}$ with a 1-week window (middle panel) and $R_{t}$ with a 2-week window (lower panel).

Figure S42. Map of cumulative number of deaths in Alberta by health service zone by the end of month and on July 6, 2020.

Figure S43. The epidemic trajectory of coronavirus disease 2019 in Calgary Zone, Alberta, January 1July 5, 2020: Daily number of new cases by date of report (upper panel), $R_{t}$ with a 1-week window (middle panel) and $R_{t}$ with a 2-week window (lower panel).

Figure S44. The epidemic trajectory of coronavirus disease 2019 in Edmonton Zone, Alberta, January 1July 5, 2020: Daily number of new cases by date of report (upper panel), $R_{t}$ with a 1-week window (middle panel) and $R_{t}$ with a 2-week window (lower panel). 
medRxiv preprint doi: https://doi.org/10.1101/2020.07.18.20156992; this version posted August 26, 2020. The copyright holder for this preprint (which was not certified by peer review) is the author/funder, who has granted medRxiv a license to display the preprint in perpetuity.

It is made available under a CC-BY-NC-ND 4.0 International license .

209 Figure S45. The epidemic trajectory of coronavirus disease 2019 in South Zone, Alberta, January 1-July

2105,2020 : Daily number of new cases by date of report (upper panel), $R_{t}$ with a 1-week window (middle

211 panel) and $R_{t}$ with a 2-week window (lower panel).

212 Figure S46. The epidemic trajectory of coronavirus disease 2019 in Central Zone, Alberta, January 1-July

213 5, 2020: Daily number of new cases by date of report (upper panel), $R_{t}$ with a 1-week window (middle

214 panel) and $R_{t}$ with a 2-week window (lower panel).

215 Figure S47. The epidemic trajectory of coronavirus disease 2019 in North Zone, Alberta, January 1-July

2165,2020 : Daily number of new cases by date of report (upper panel), $R_{t}$ with a 1-week window (middle

217 panel) and $R_{t}$ with a 2-week window (lower panel).

218 Figure S48. Sensitivity analysis (confirmed cases only): The epidemic trajectory of coronavirus disease

2192019 in Alberta, 2020: Daily number of new confirmed cases by date of report (upper panel), $R_{t}$ with a 1-

220 week window (middle panel) and $R_{t}$ with a 2-week window (lower panel).

221 Figure S49. Scatter plot of the time difference between symptom onset (accurate episode date) and test

222 report date of each case-patient in Ontario over time (accurate episode date), Jan 1-July 6, 2020. 


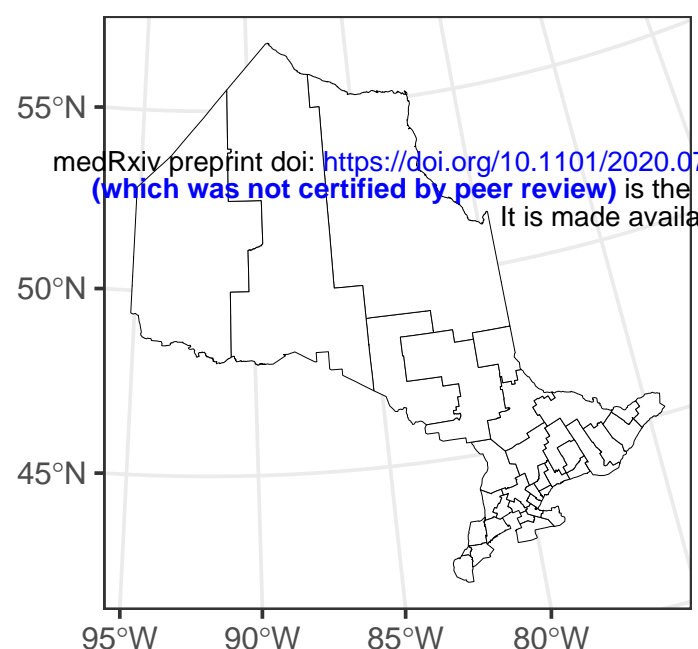

31 March, 2020

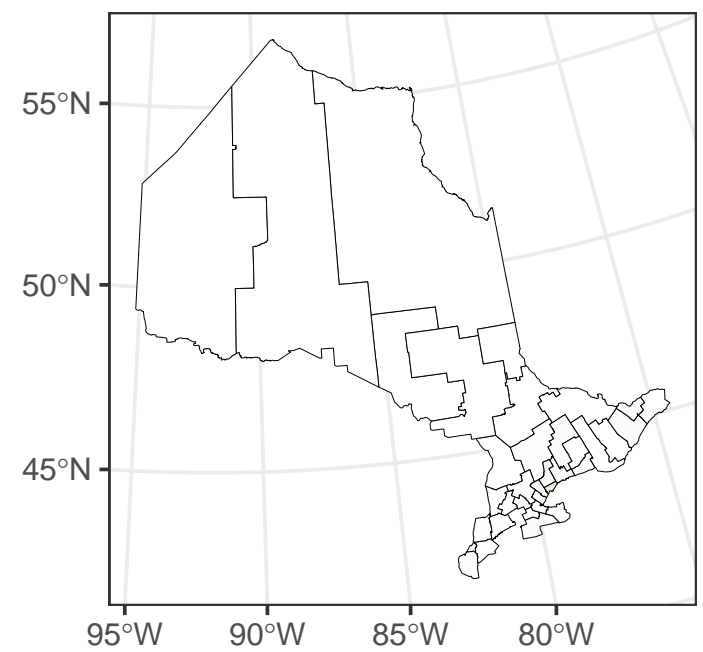

31 May, 2020

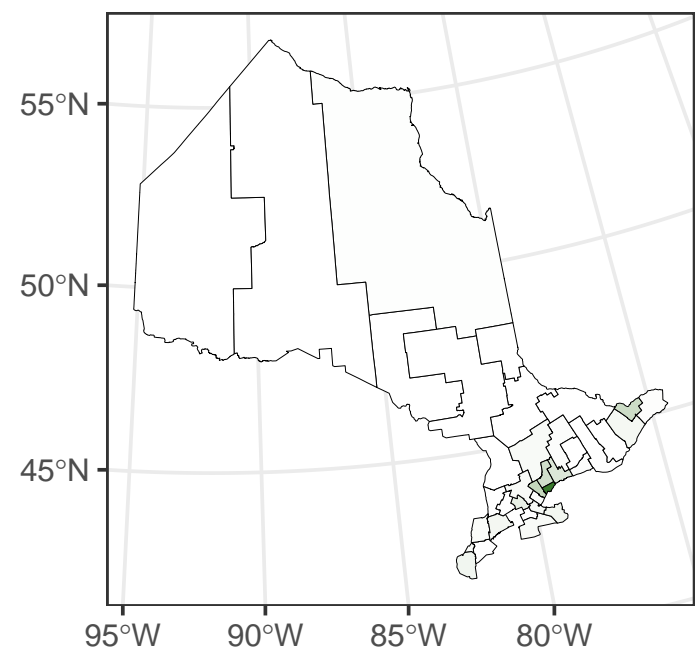

05 July, 2020

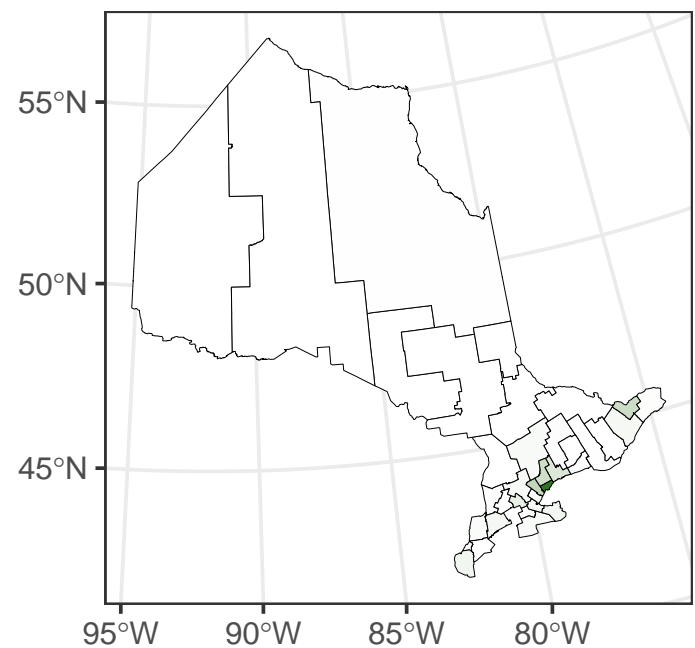

$55^{\circ} \mathrm{N}$

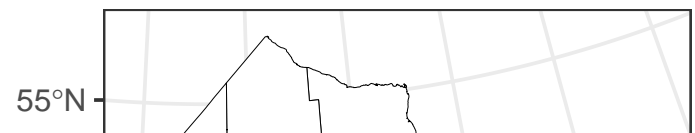

7.18.20156992; this version posted August 26, 2020. The copyright holder for this preprint

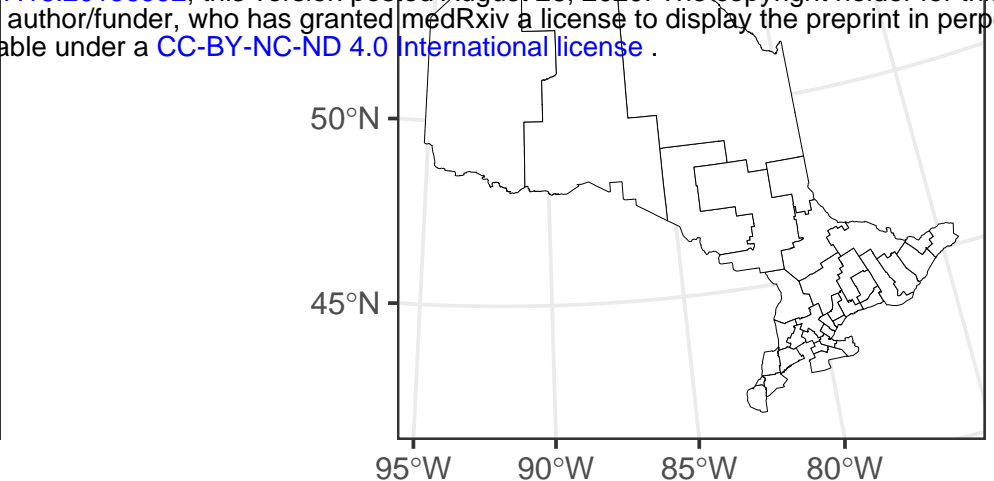

30 April, 2020

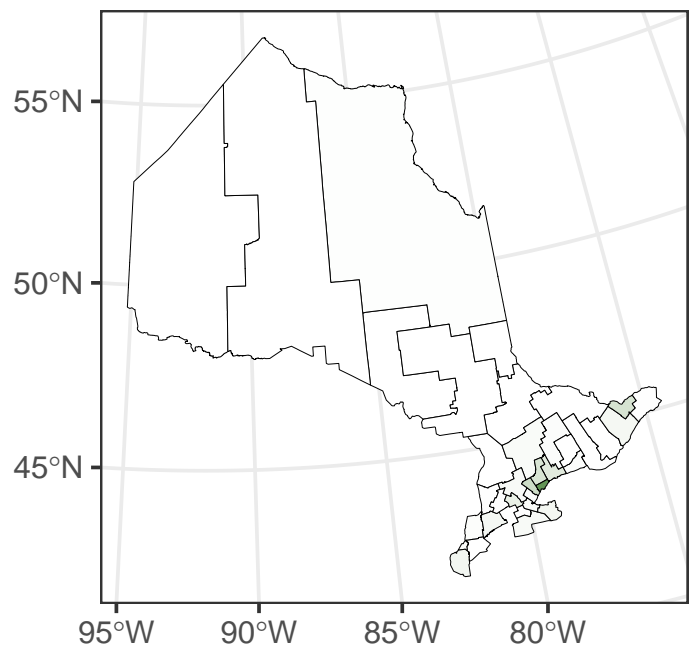

30 June, 2020

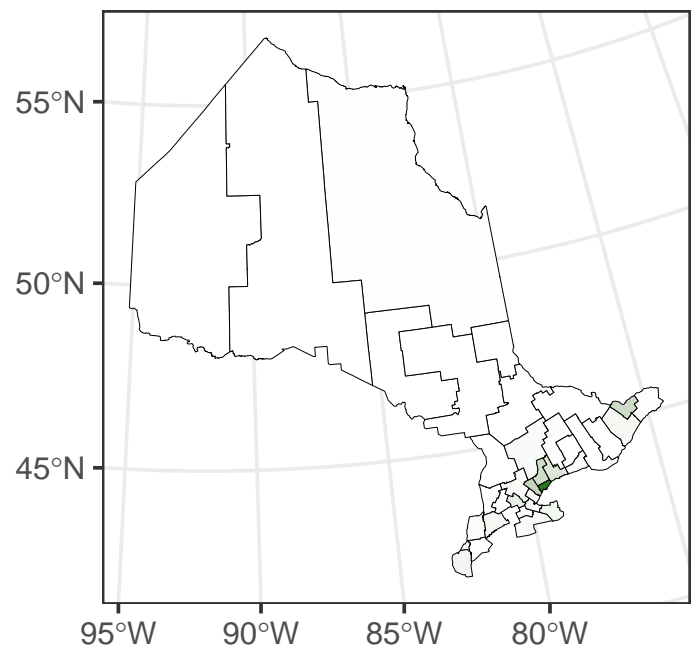

No. of cases

1200

900

600

300

0 
Peel Public Health
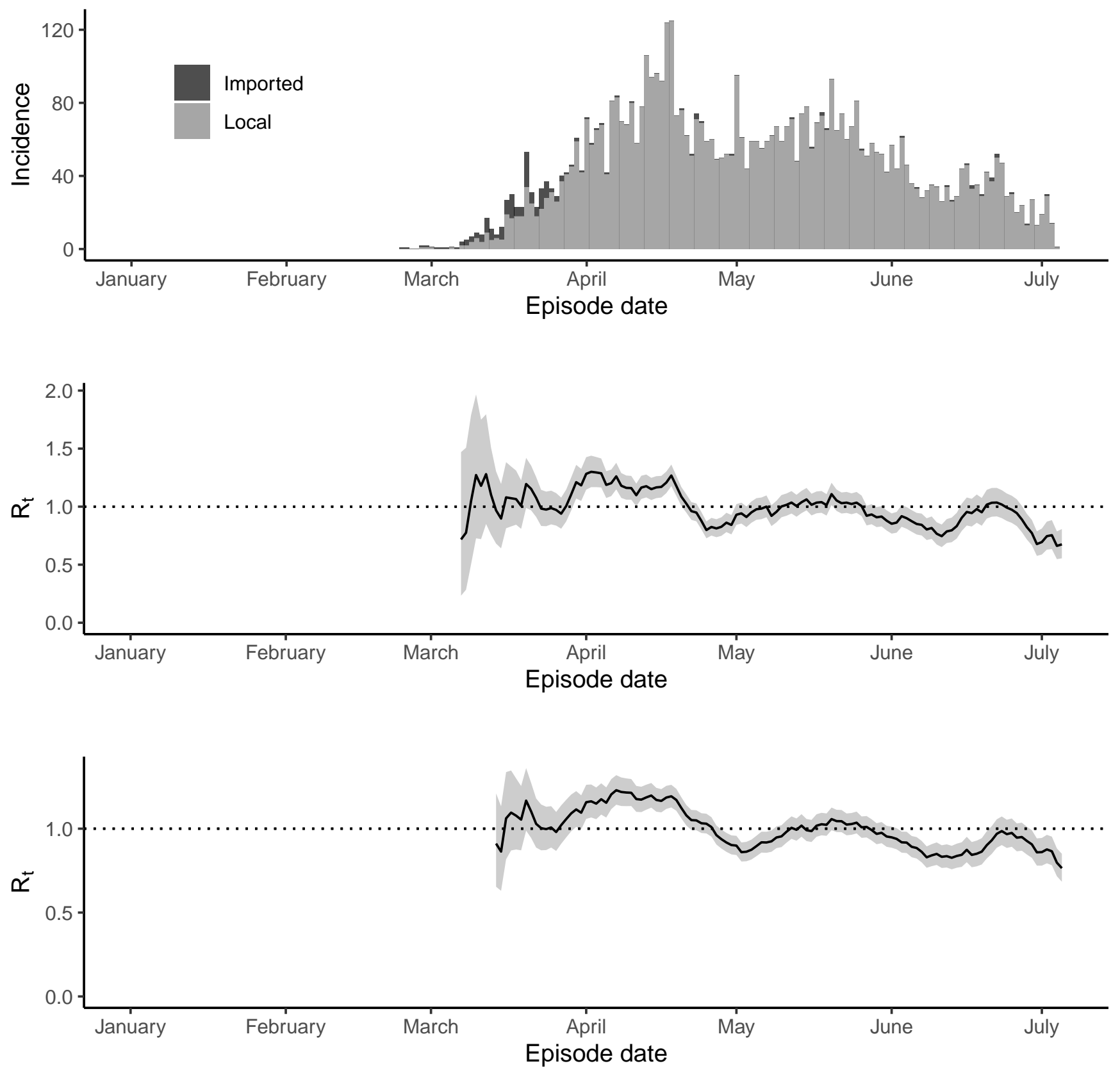
York Region Public Health Services
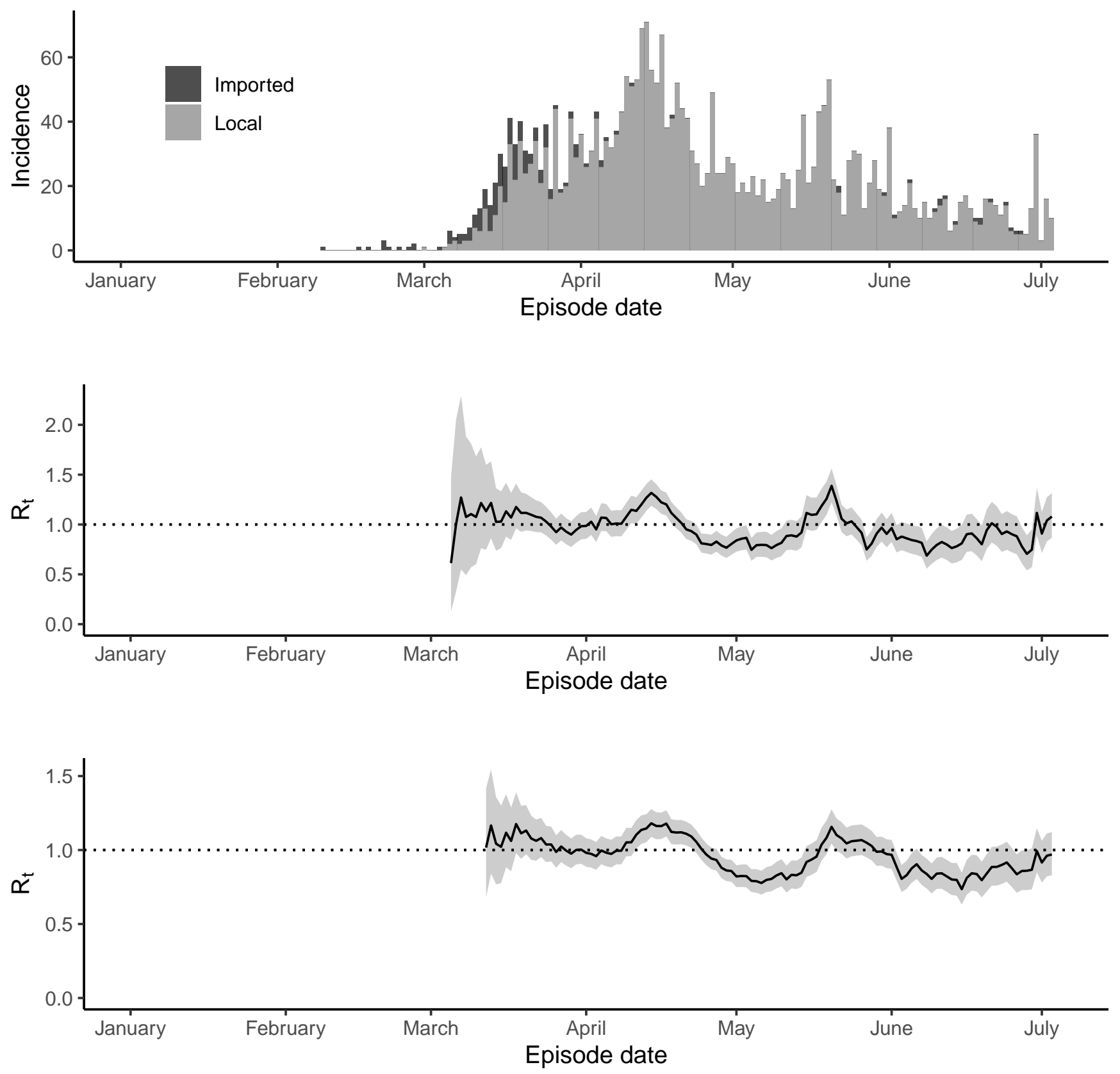
Region of Waterloo, Public Health
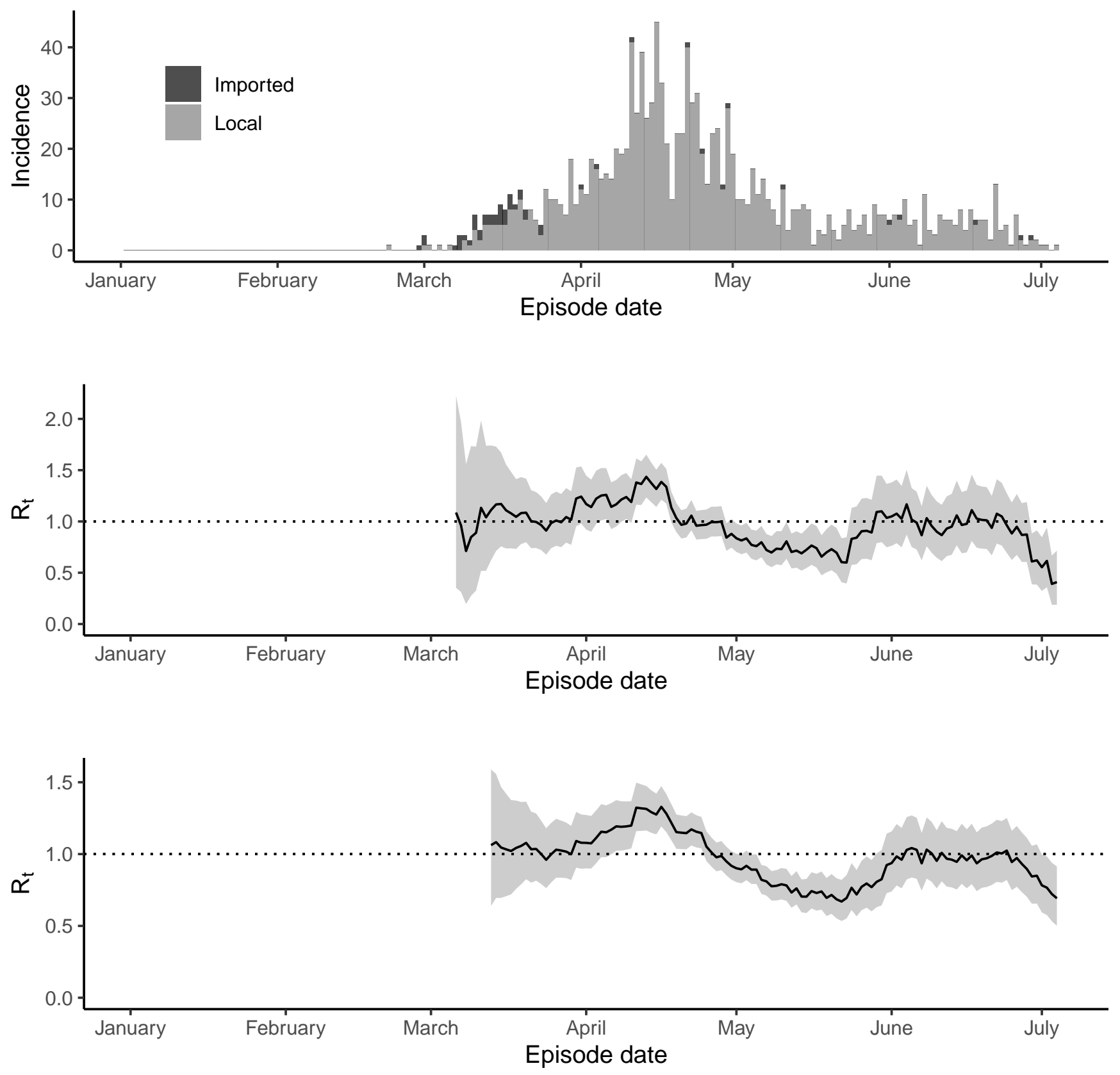


\section{Ottawa Public Health}
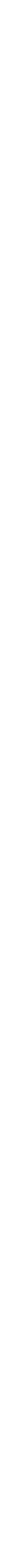
Kingston, Frontenac and Lennox \& Addington Public Health
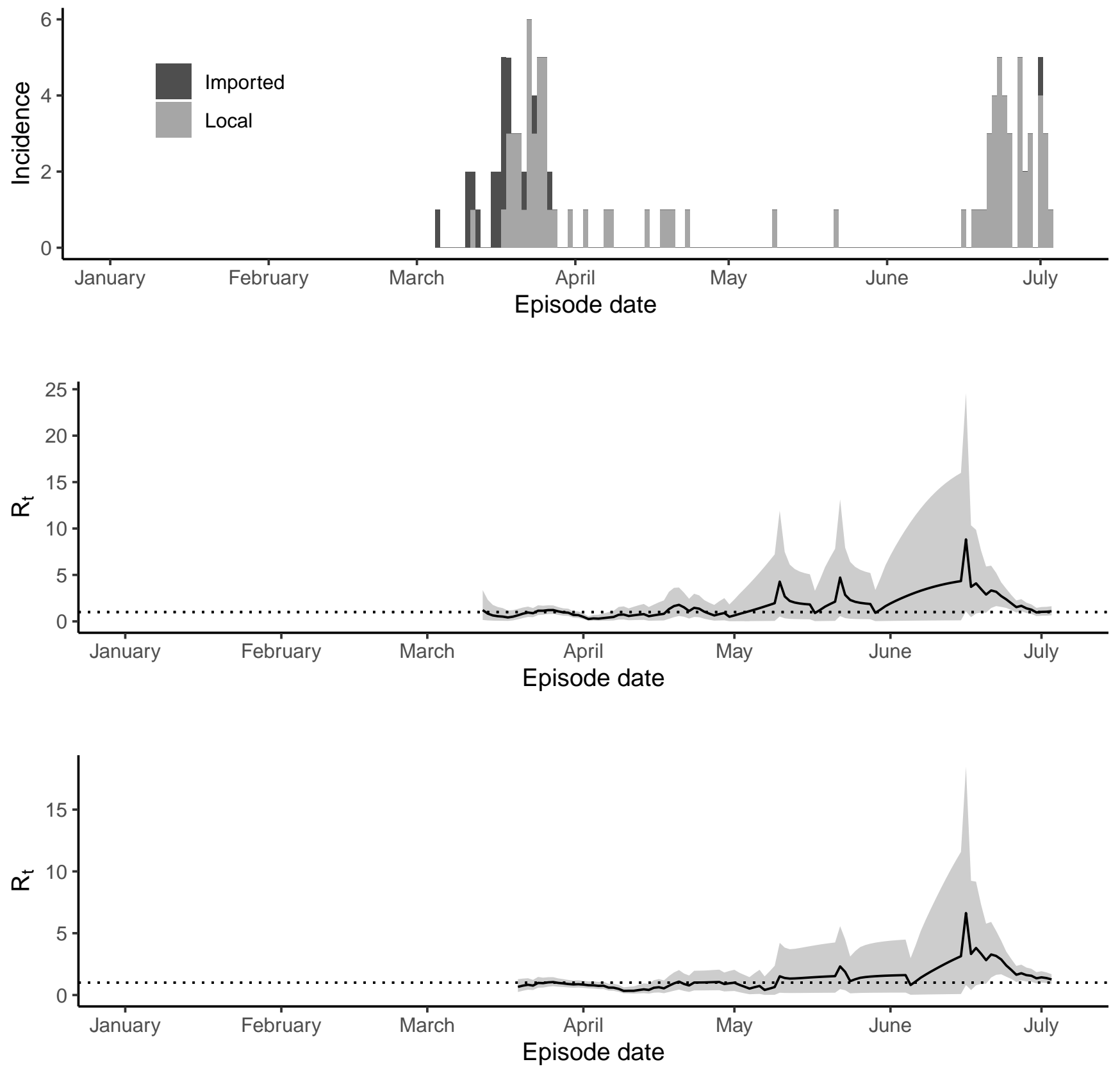
North Bay Parry Sound District Health Unit
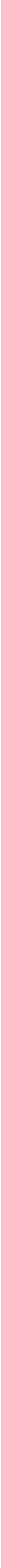
Porcupine Health Unit
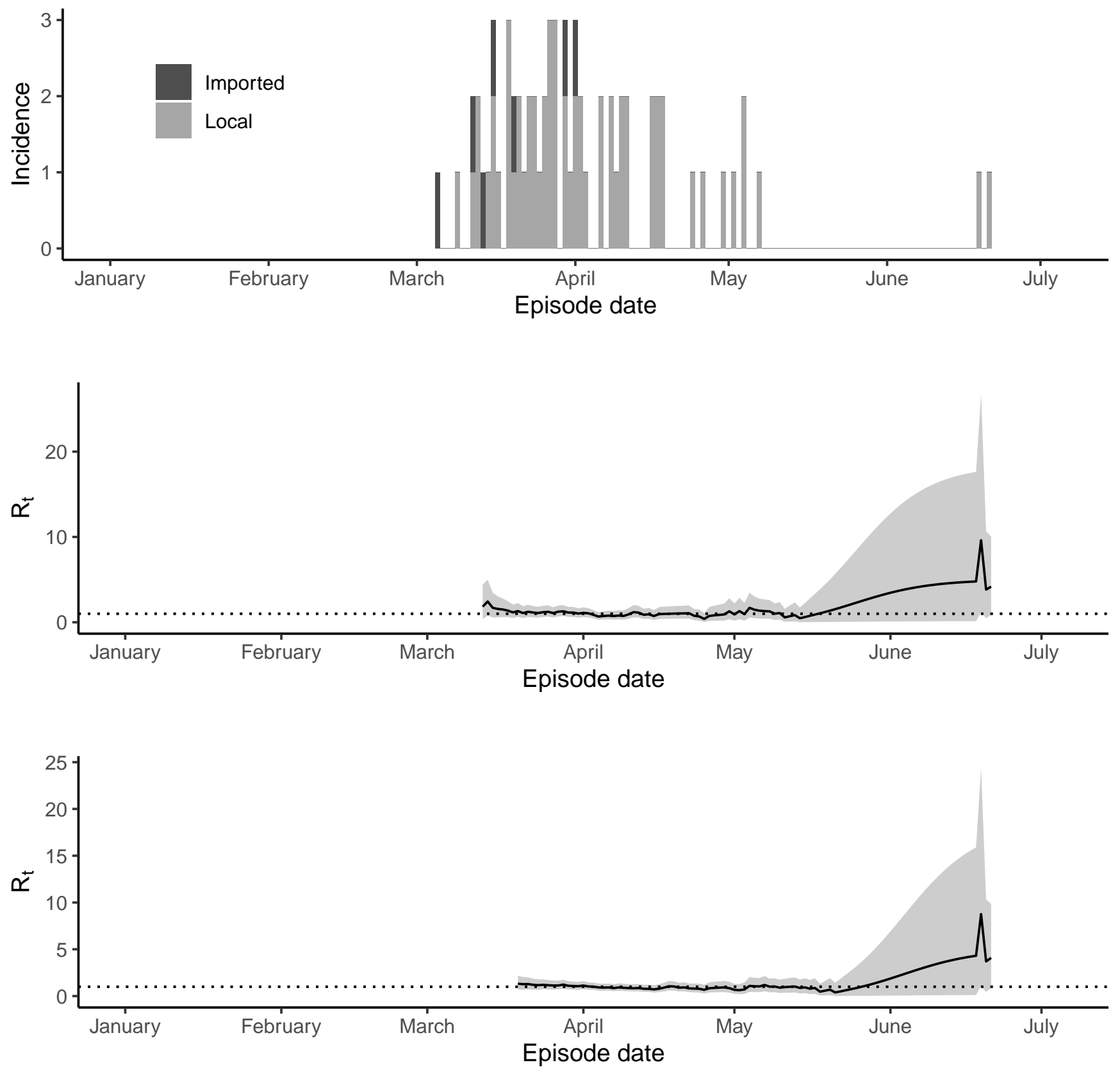
Thunder Bay District Health Unit
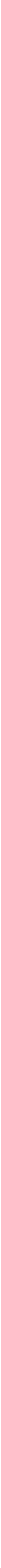
Wellington-Dufferin-Guelph Public Health
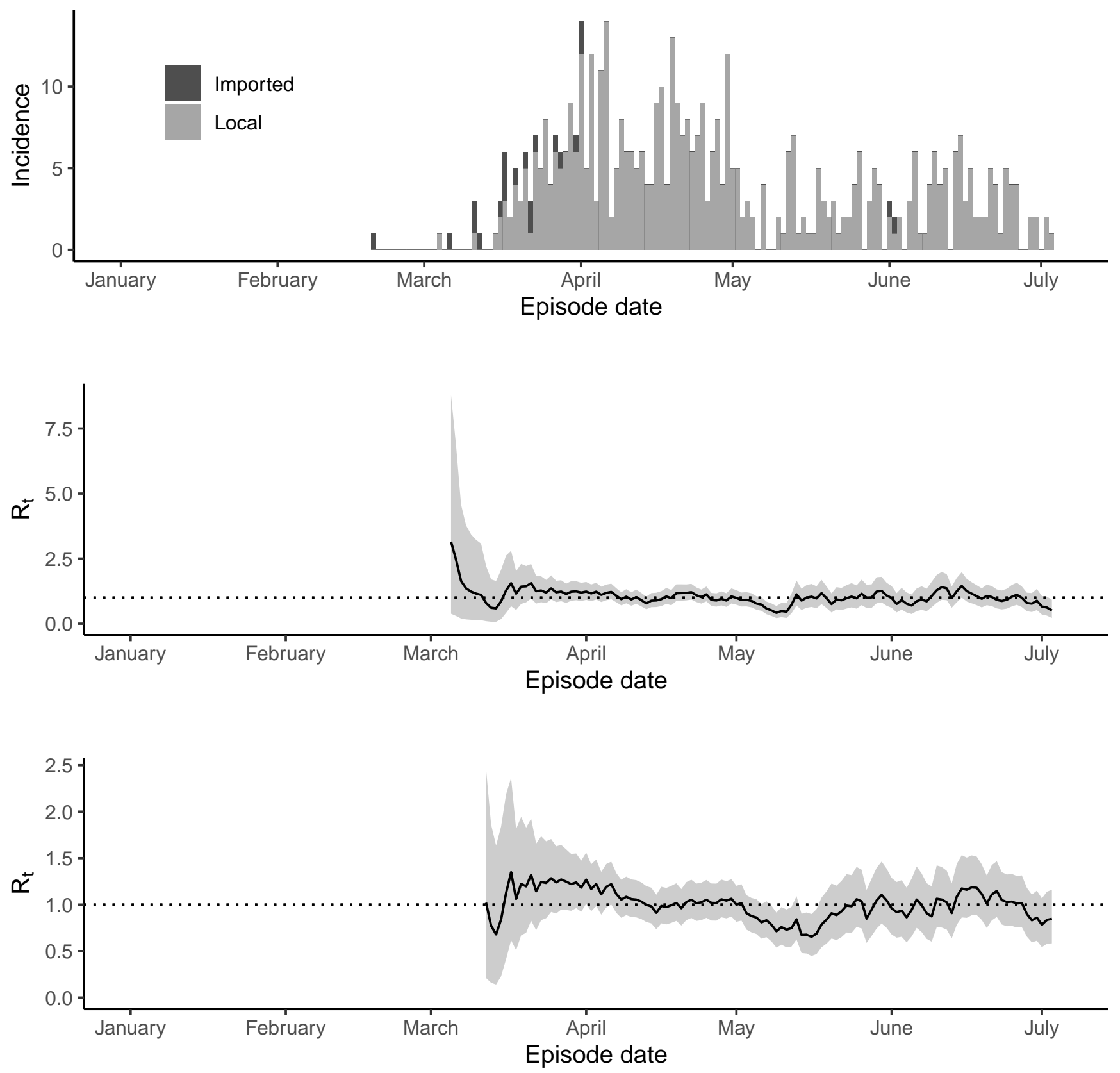
Windsor-Essex County Health Unit
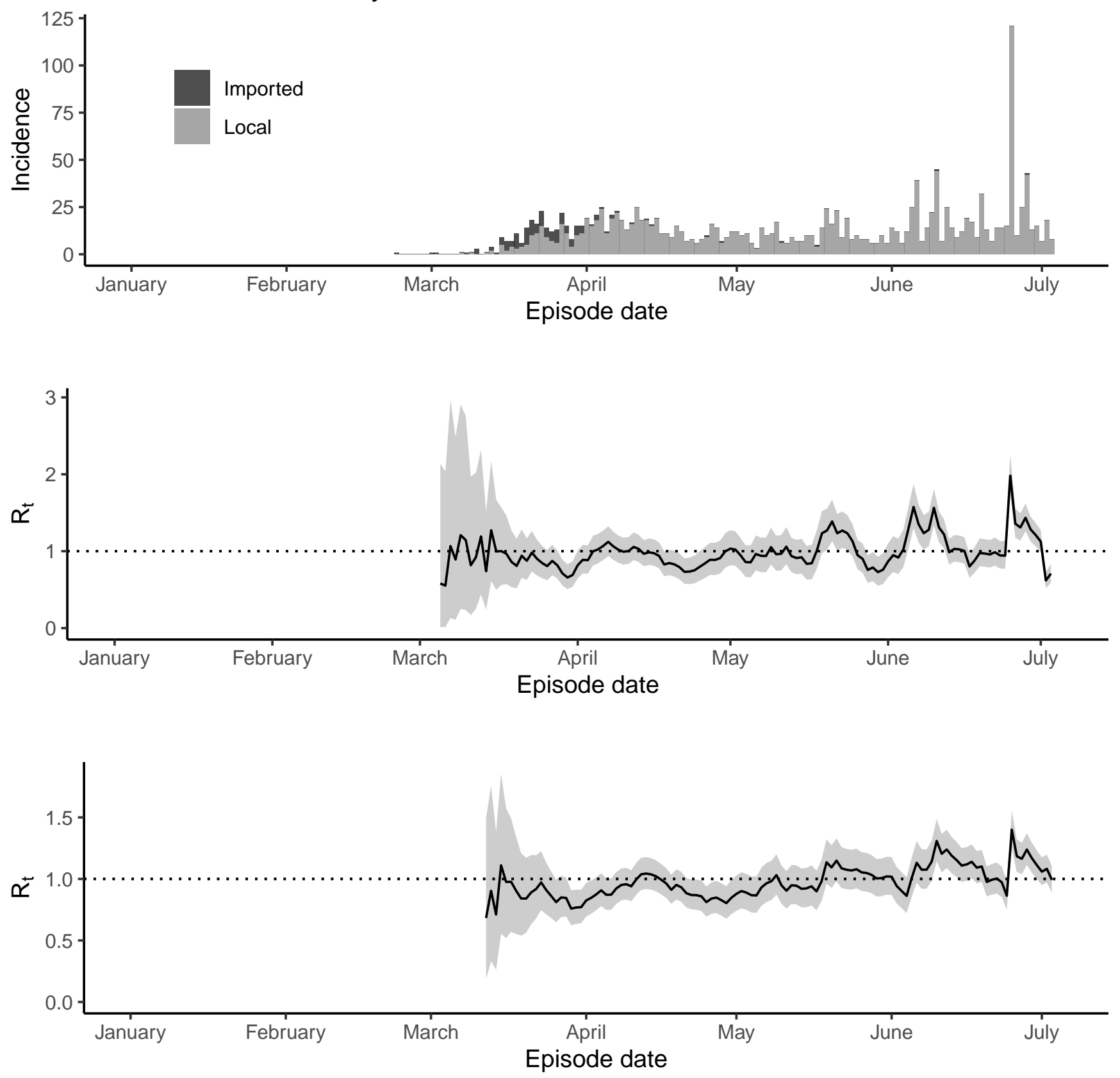
Interior, BC
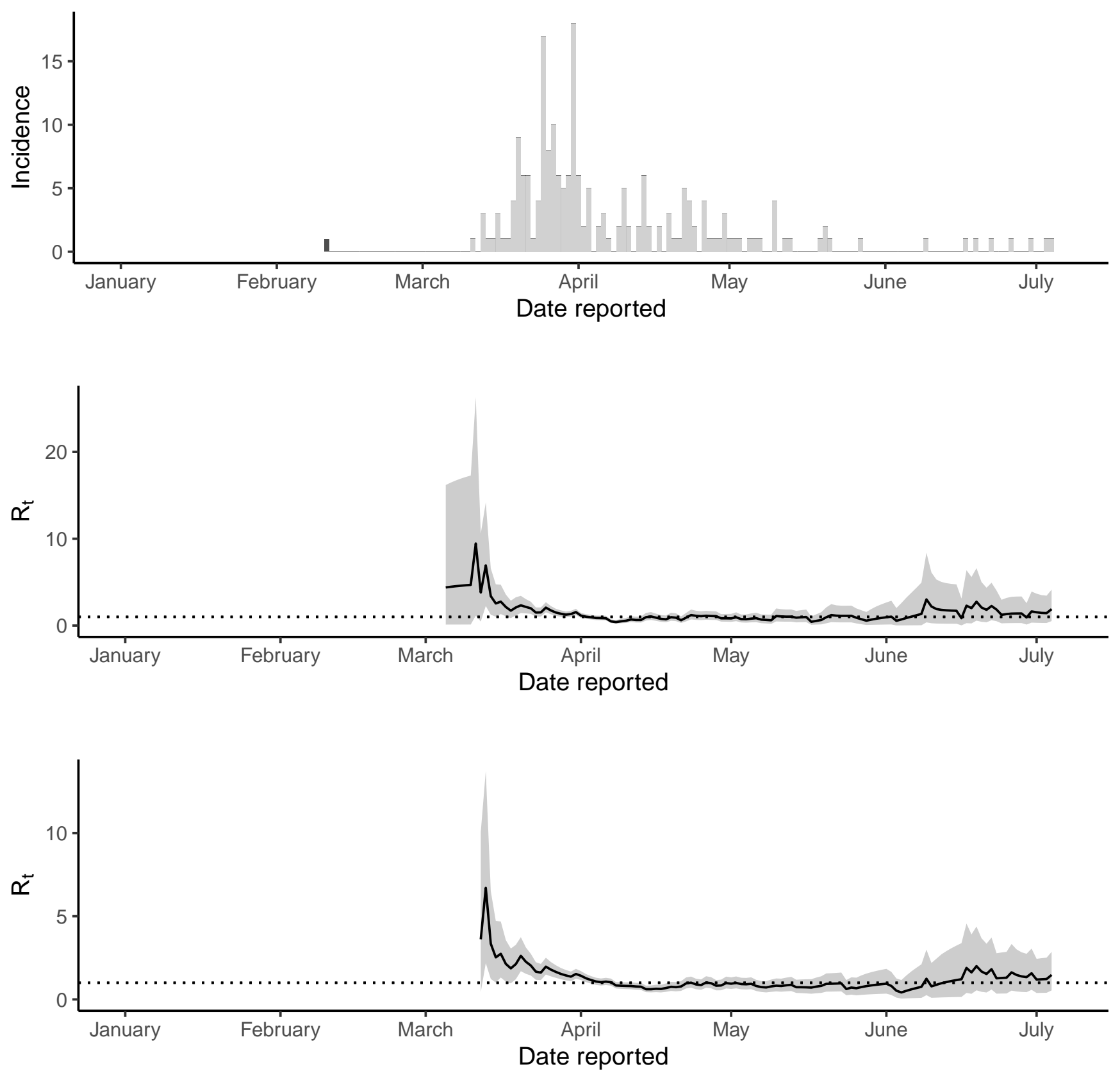
British Columbia (Lab-diagnosed only)
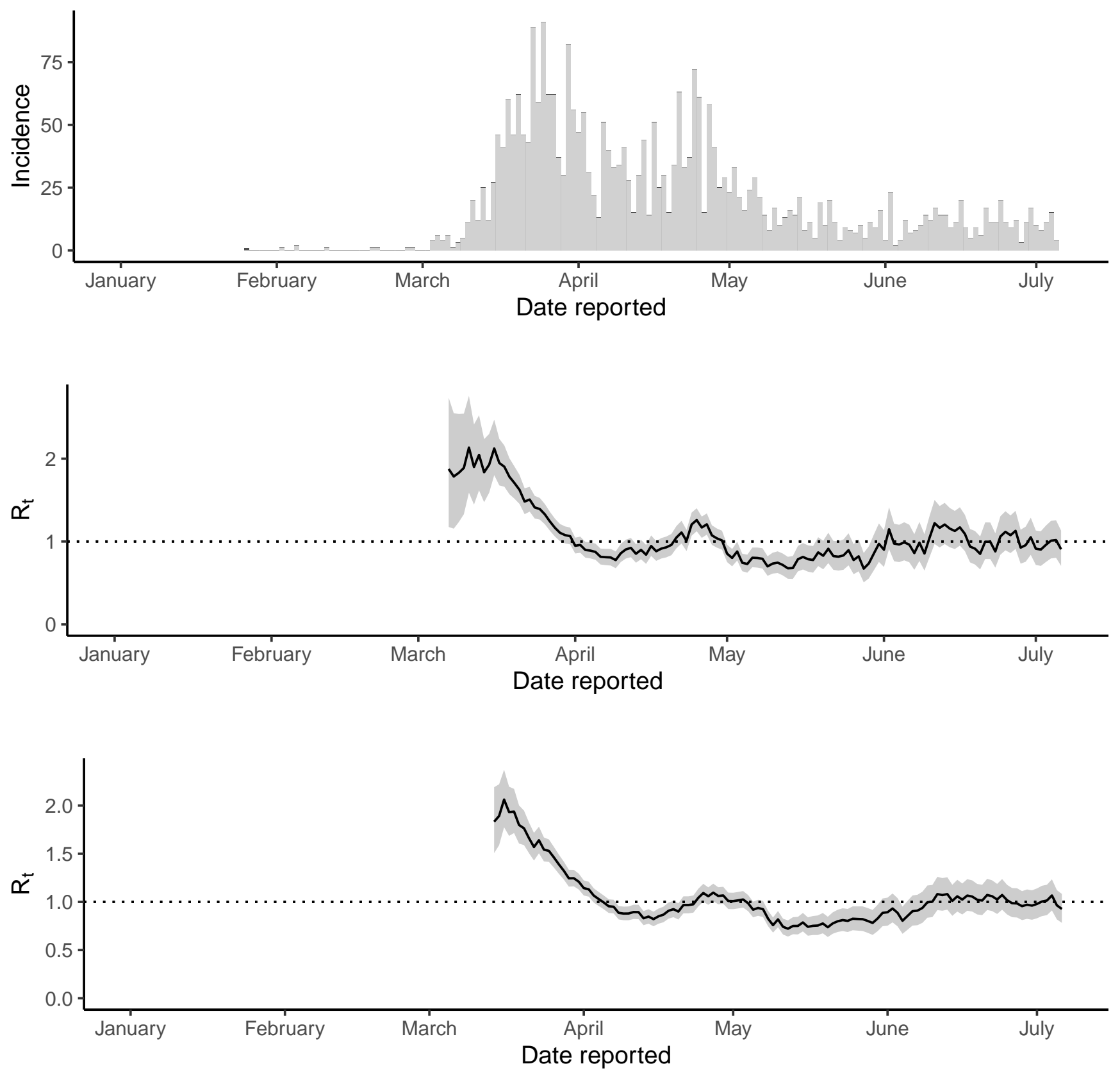

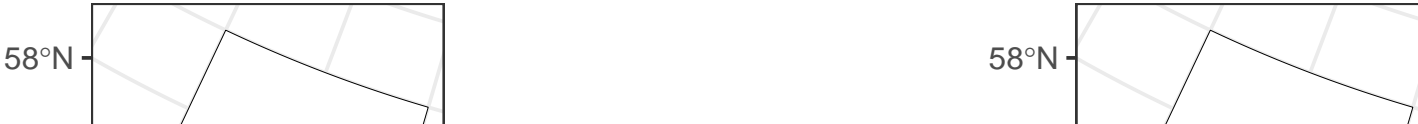

medRxispreprint doi: https://doi.org/10.1101/2020.07.18.20156992; this version posted-Auqust 26, 2020. The copyright holder for this preprint (which was not certified by peer review) is the author/funder, who has granted medRxiv a license to display the preprint in perpetuity.

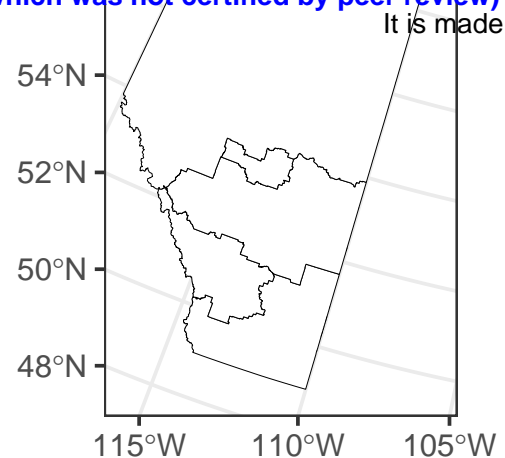

31 March, 2020

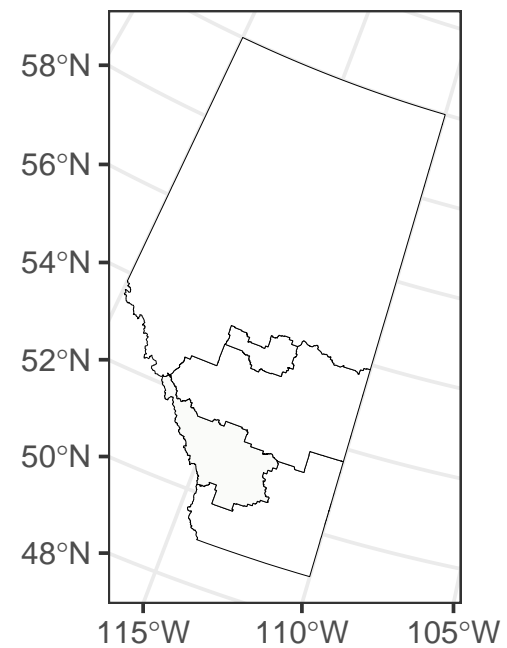

31 May, 2020

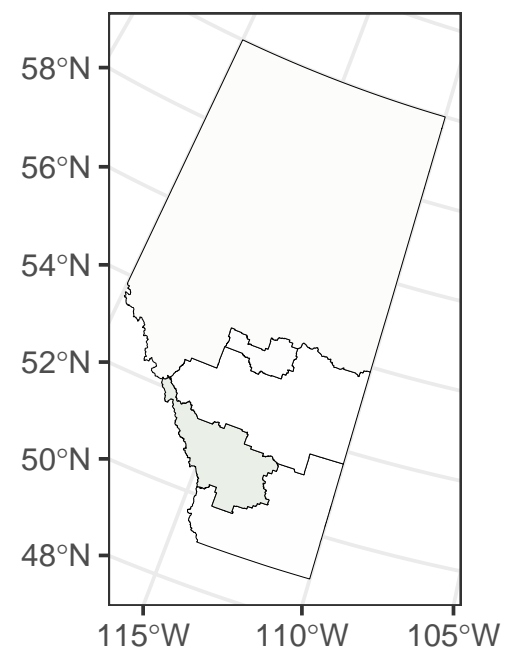

05 July, 2020

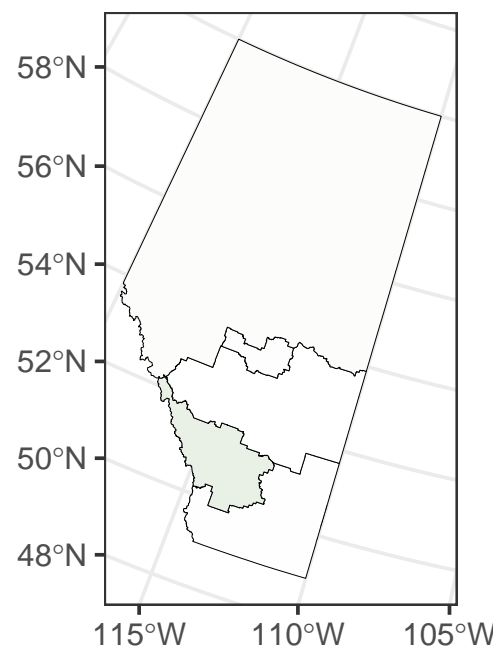

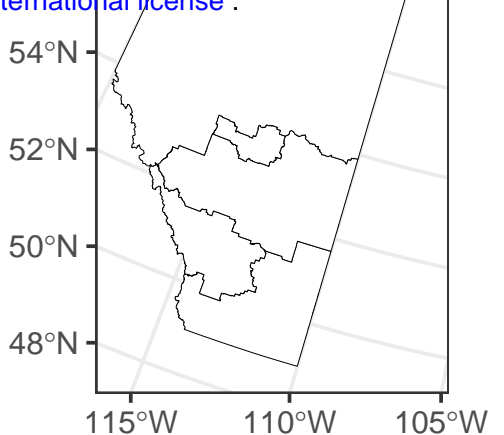

30 April, 2020

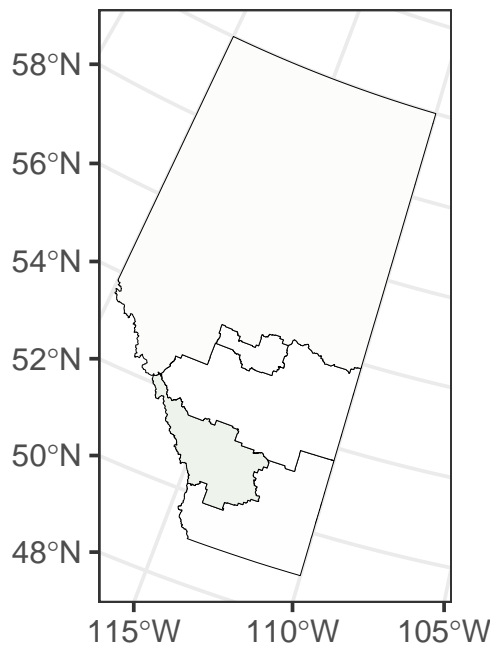

30 June, 2020

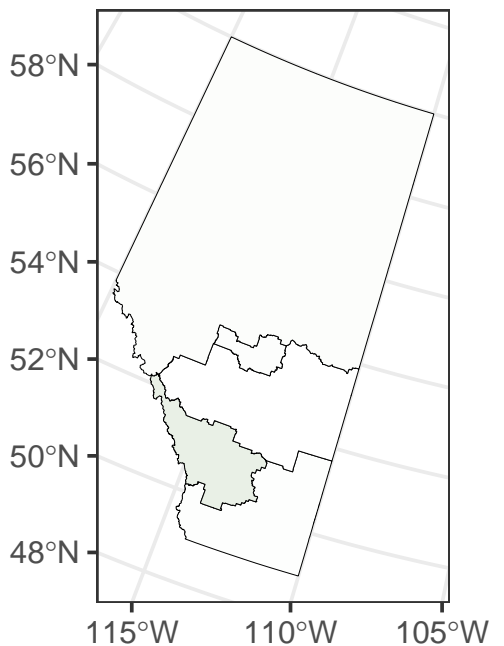

No. of cases

$$
1200
$$

900

600

300 
Edmonton Zone, AB
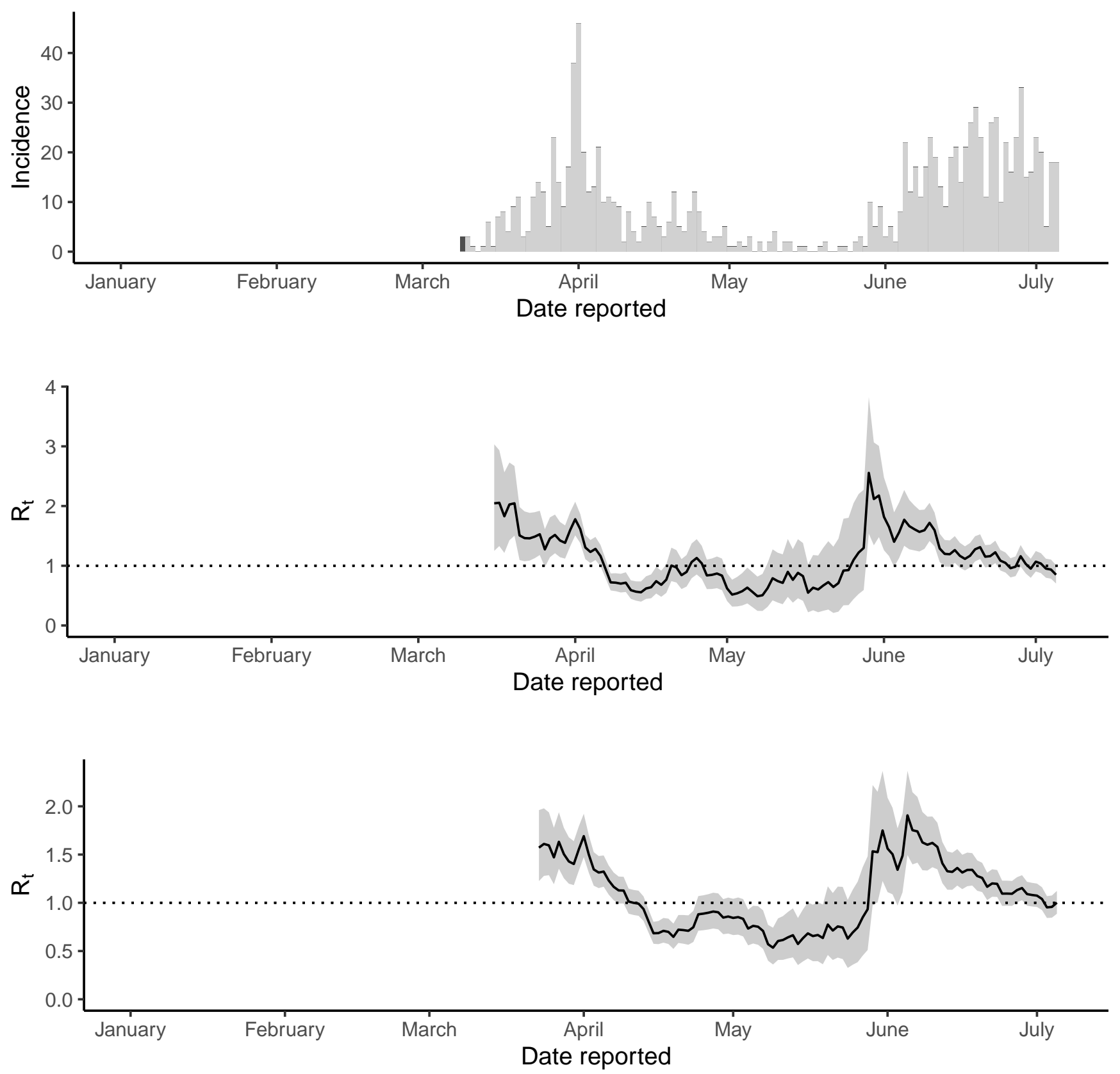


\section{Central Zone, AB}
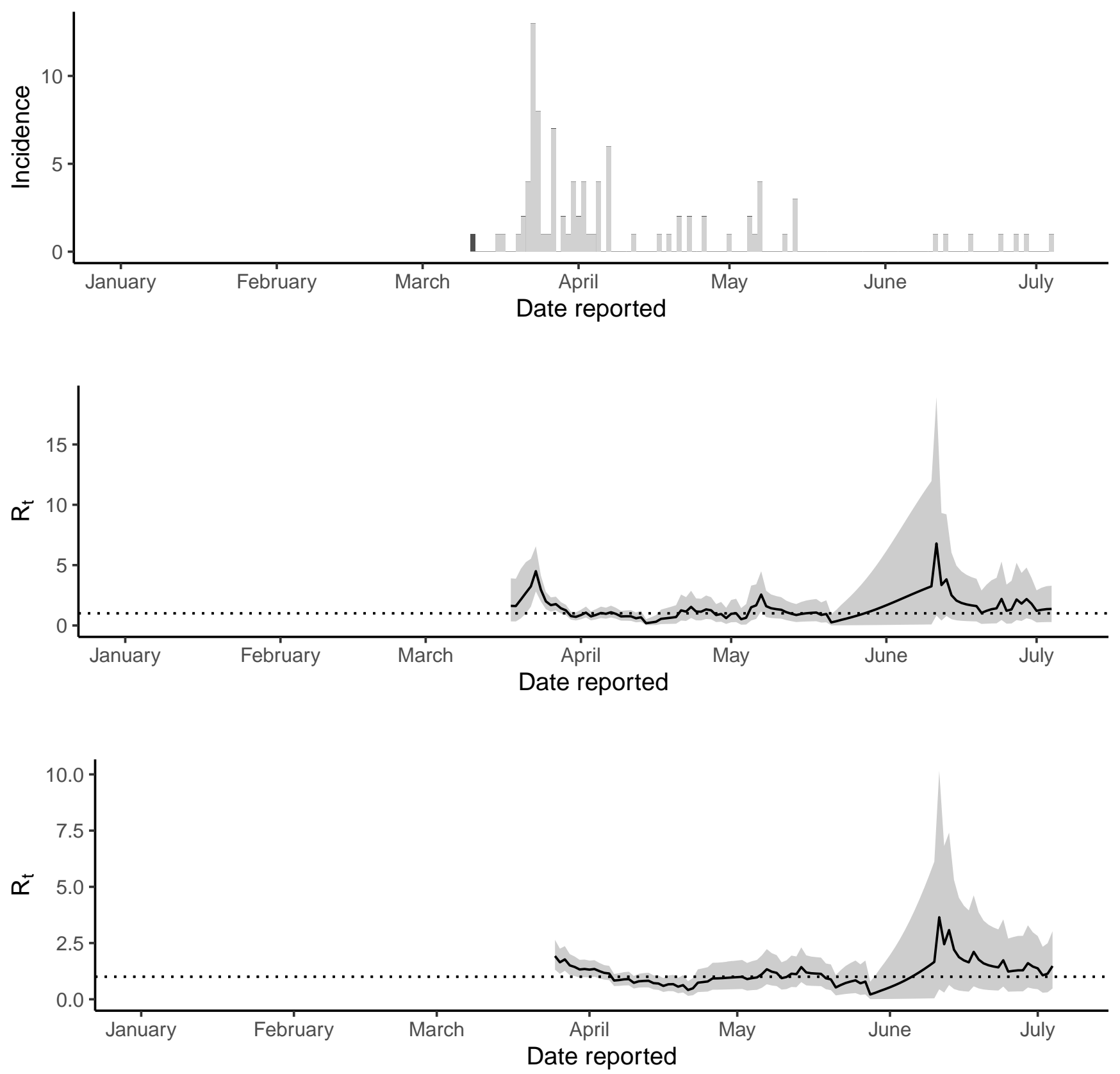
Alberta (Confirmed cases only)
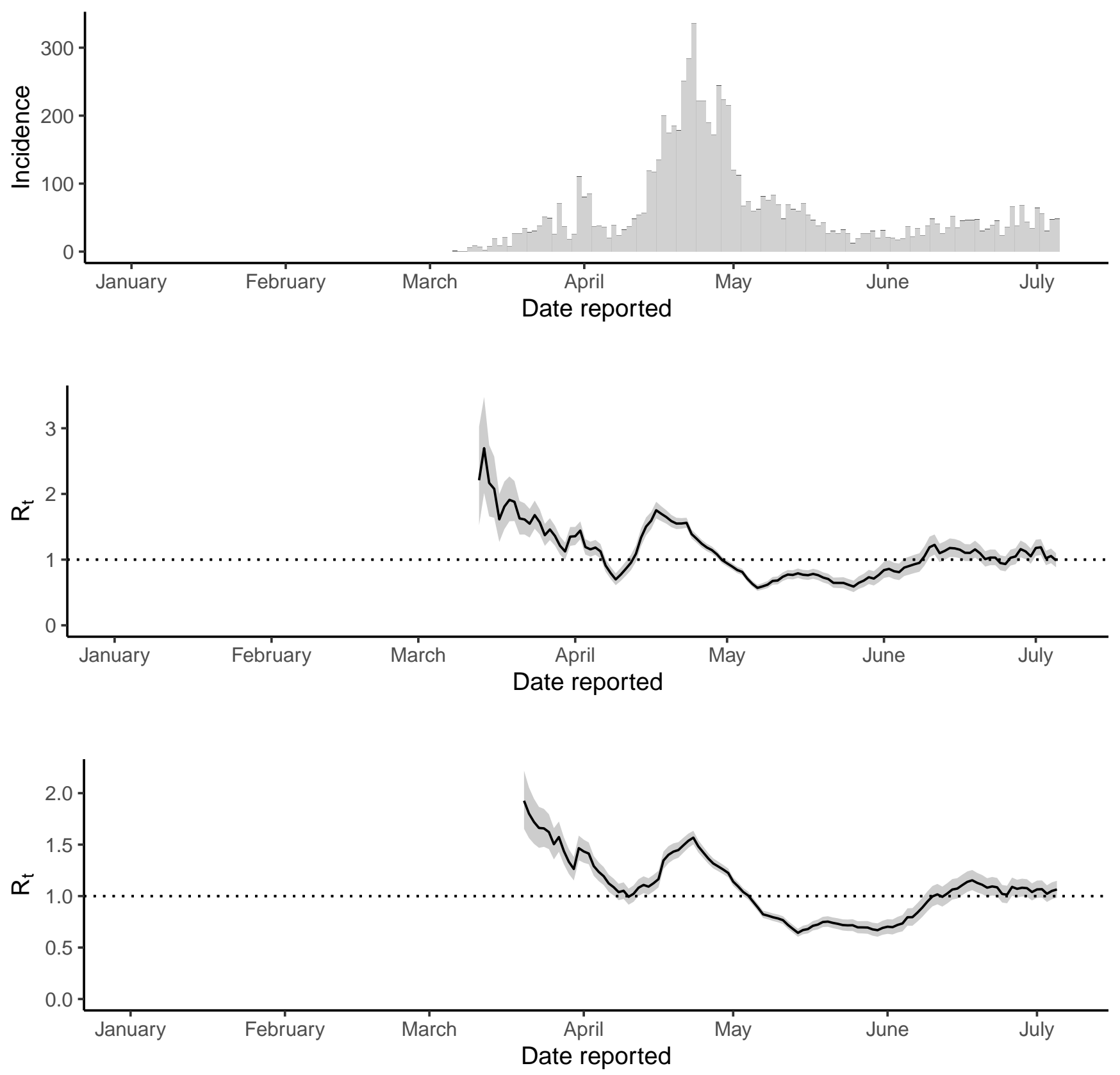


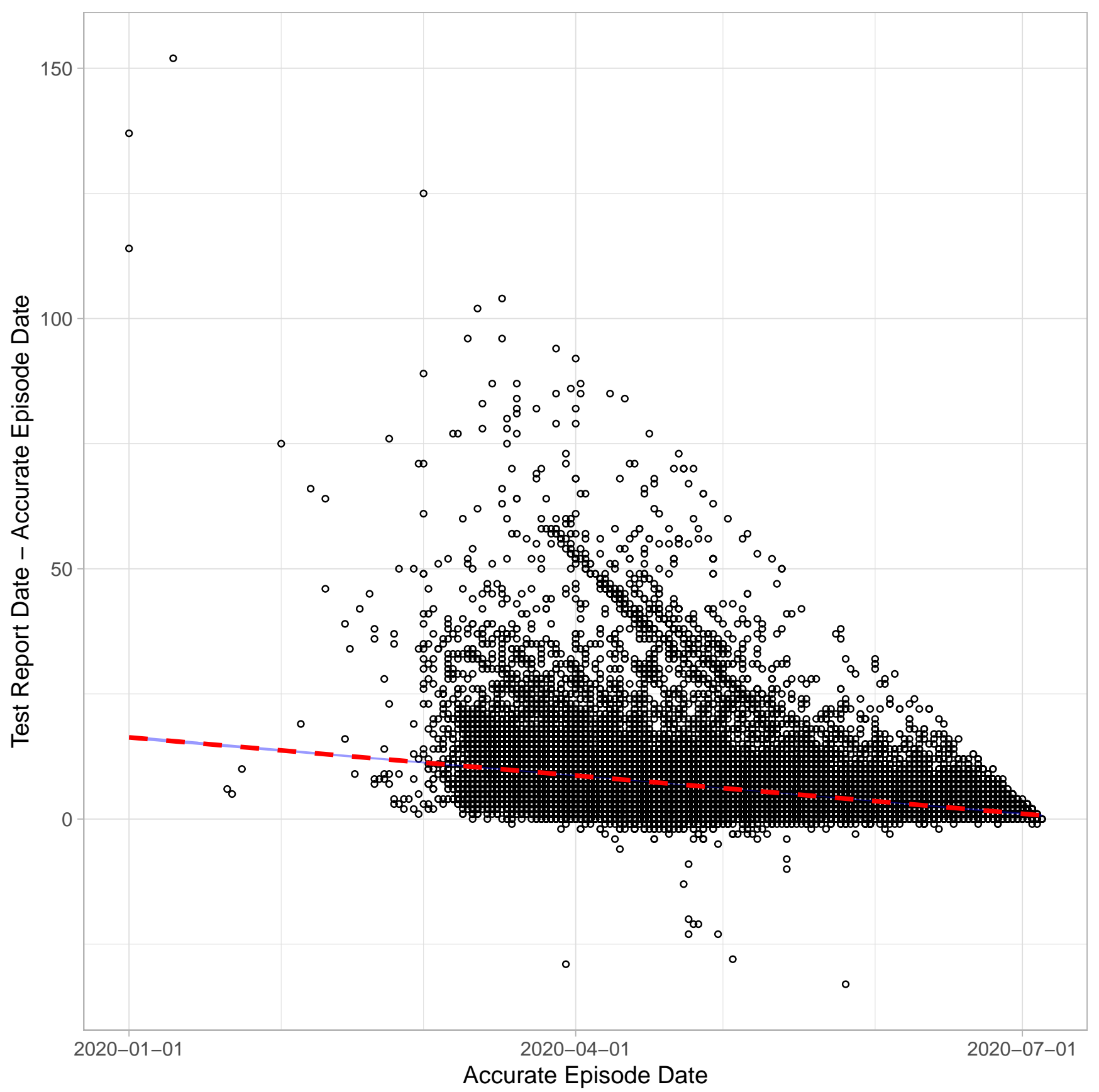

